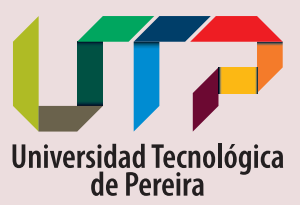

Facultad de Bellas Artes y Humanidades

\title{
Mimesis I: Platón
}


Luis Guillermo Quijano Restrepo Leonardo Londoño López Editorial UTP Jorge Armando Ardila Robledo 


\section{Mimesis I: Platón}

Luis Guillermo Quijano Restrepo

Leonardo Londoño López

Jorge Armando Ardila Robledo

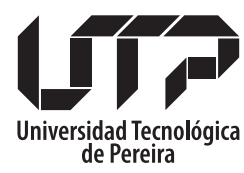

Colección Trabajos de Investigación

Facultad de Bellas Artes y Humanidades

2016 
Quijano Restrepo, Luis Guillermo

Mimesis I : Platón / Luis Guillermo Quijano Restrepo, Leonardo Londoño López, Jorge Armando Ardila Robledo. - Pereira : Editorial Universidad Tecnológica de Pereira, 2016.

99 páginas. - (Colección Trabajos de investigación)

ISBN: 978-958-722-264-7

e-book

1. Mimesis en la literatura 2. Representación filosófica 3. Política filosófica

4. Realismo 5. Imitación 6. Filosofía griega 7. Platón 8. Filosofía platónica

CDD. 184

(C) Luis Guillermo Quijano Restrepo

(C) Leonardo Londoño López

(C) Jorge Armando Ardila Robledo

(C) Universidad Tecnológica de Pereira

Primera edición, 2016

ISBN: 978-958-722-264-7

e-Book

Proyecto de investigación titulado MIMESIS I: PLATON, inscrito con el código 1-11-5

Universidad Tecnológica de Pereira

Vicerrectoría de Investigaciones, Innovación y Extensión

Editorial Universidad Tecnológica de Pereira

\section{Coordinador editorial UTP}

Luis Miguel Vargas Valencia

luismvargas@utp.edu.co

Tel:3137381

Edificio 9, Biblioteca Central “Jorge Roa Martínez" 9/N1/110

Cra. 27 No. 10-02 Los Álamos

Pereira, Colombia

www.utp.edu.co

\section{Montaje y producción:}

Universidad Tecnológica de Pereira

Centro Recursos Informáticos y Educativos, CRIE

\section{Reservados todos los derechos}


Los autores desean expresar su reconocimiento al programa de Maestría en Filosofía en cabeza de su director, Doctor Carlos Eduardo Peláez Pérez, al igual que a la Facultad de Bellas Artes y Humanidades de la Universidad Tecnológica de Pereira, por hacer posible la publicación de este libro. 


\section{Contenido}

Introducción $\quad 5$

I. Mímesis y el cuerpo bello (la percepción) 8

Leonardo Londoño López

II. Mímesis y poesía enamorada

23

Jorge Armando Ardila Robledo

III. La mímesis poética y su relación con el saber

34

Luis Guillermo Quijano Restrepo

IV. Mímesis y educación

71

Jorge Armando Ardila Robledo

V. Mímesis, inspiración y política en Platón

80

Luis Guillermo Quijano Restrepo

VI. Epílogo

96 


\section{Introducción}

¿En qué sentido es todavía vigente el topos de la mimesis platónica? Podría ser el hilo conductor de las reflexiones que se suscitan en los artículos que conforman este texto. Preguntarnos por la vigencia de este término para la estética no es en vano, como tampoco lo es para la educación, el cuerpo, la política o la ética. El aspecto negativo de la mímesis que subyace a la postura platónica es posiblemente la causa de esta vigencia. Sin embargo, y en esto nos detendremos más, no es solo este aspecto, sino también su contrario, el positivo, el que también se puede vislumbrar, $\mathrm{y}$ es por esto, el menos conocido, y por lo tanto, menos apetecido para profundizar.

Se le recrimina a Platón el haber expulsado a los poetas (otros autores dicen que fue la poesía la que expulsó); también el que haya considerado las artes miméticas en general inferiores al conocimiento de las formas; que hubiese hecho, además, un uso utilitario de las mismas a favor de la educación de los guerreros del Estado; en fin, que hubiera dejado tan mal parada a las artes en general y a la mimesis como su representación ante el conocimiento real. Recordemos que todas ellas están alejadas de lo real, tres grados. Esto lleva en primera instancia a tener una sospecha de la "veracidad" de las mismas. Por ello Platón no duda en criticar a los poetas (en primer lugar a Homero, Hesíodo y los trágicos en general), más aún, los aleja del Estado mismo y les niega la posibilidad de volver a este si no cambian su modo de representar la divinidad misma. Es que el asunto de la representación es la clave para entender la posición "negativa" de Platón hacia la poesía, por ello consideramos que este es solo un aspecto superficial de la crítica a la mimesis y a las artes y a los poetas. La mimesis en sí no es ni buena, ni mala; solo que su modo de darse se convierte en buena o mala según se corresponda o no a la naturaleza misma que representa. Así, si se trata de imitar la naturaleza humana, debe esta corresponder a su naturaleza racional, y si se trata de imitar la naturaleza divina, debe corresponder a todas sus perfecciones.

Es en este sentido que proponemos al público lector e investigador en filosofía antigua, una serie de reflexiones que apuntan a mostrar el modo "positivo" que se puede encontrar tras la lectura del modo "negativo" de la posición de Platón sobre las artes y la mimesis. 
Es así que el presente texto titulado Mimesis I: Platón, es la colección de cinco ensayos que giran en torno al tópico de la mimesis en relación con diversos campos, además del arte, tales como la ética, la política, la educación y la corporeidad, los cuales tienen por hilo conductor la filosofía de Platón. En primer lugar encontramos una aproximación desde el cuerpo como encarnación de la belleza misma que es percibida; luego pasamos a la mimesis encarnada esta vez en los enamorados que expresan su philia por medio de la poesía. Esta a su vez, a pesar de la crítica de Platón a aquella, puede utilizarse en tanto "mentira verdadera" como pharmako contra aquellas "mentiras innobles" a las que recurre el poeta para realizar sus imitaciones. Esto nos conduce al problema de la educación en la que se indaga por aquella representación que movía al espíritu griego en su paideia, como ideal para pensar la educación aun en nuestros días. Finalmente, se retoma la poesía como mimesis e inspiración que se sintetizan en la figura del poeta legislador que determina el modo adecuado de representación para el buen gobierno del Estado.

Desde esta perspectiva, este libro va dirigido sobre todo a los estudiantes de pregrado que cursen y gusten de asignaturas como estética antigua o afines a esta, sean estos estudiantes de filosofía; también a todos aquellos que se orienten hacia las áreas de las humanidades que versen sobre estos tópicos en general. Es Mimesis I: Platón, un texto que recoge diferentes visiones sobre el tópico de la mimesis platónica y pretende actualizarlo tanto en el tiempo como en otras áreas del saber y de la producción humana. No es la intención de este, hacer un trabajo de gran erudición ni de alto vuelo teórico, sino más bien, proporcionarle al potencial lector, sea estudiante o no de filosofía, una manera de poder abordar problemas clásicos, con bibliografía asequible y desde perspectivas que atañen directamente a su formación y, por qué no, incentivar la aplicación de estas reflexiones en su quehacer profesional y personal. De esta manera, los autores hacen un esfuerzo por configurar un corpus mimético básico desde cada una de las perspectivas que allí se abordan, de suerte que sean un referente para posteriores investigaciones más especializadas tanto para los estudiantes como para los propios investigadores. Esta investigación al abordar la mimesis desde temas como la política, la educación, la ética, el arte, entre otras, se aleja de una línea de investigación especializada que busca agotar el tema desde una mirada unilateral y unidisciplinar, lo cual consideramos ha sido uno de los errores de la investigación filosófica actual. Por ello, consideramos importante aquí reivindicar para la filosofía, su naturaleza multilateral, transversal y compleja.

Luego de esta breve reseña de los artículos que conforman este texto, consideramos importante hacer también una consideración contextual del grupo de investigación en "Estética y Expresión" y del proyecto que adelanta.

El grupo de investigación en Estética y Expresión nace en el año 2008 como necesidad sentida de profundizar en los estudios estéticos, máxime que el programa 
cuenta con una línea de estética y se encuentra adscrito a la Facultad de Bellas Artes y Humanidades de la Universidad Tecnológica de Pereira. Antes de su formalización en el 2008, el grupo se había iniciado como grupo de estudio con algunos estudiantes de último semestre y egresados del programa en Licenciatura en Filosofía, los cuales nos reuníamos en torno al estudio de los textos de los antiguos (Heráclito, Platón, Aristóteles, entre otros) para leerlos, analizarlos, discutirlos y realizar, a partir de motivaciones individuales, algunos escritos sobre ellos. Algunos de esos escritos se convirtieron en trabajos de grado sobre esta temática. Ya en 2010, el grupo propuso este proyecto de investigación y comenzó a reunirse regularmente para estudiar ya más específicamente el topos de la mímesis en Platón. El resultado de esto, en parte es este texto de Mimesis I: Platón. Decimos en parte porque se quedaron por fuera otros textos y otros integrantes debido a que algunos no se concluyeron, o bien, otros no correspondían a los objetivos trazados dentro del grupo. Uno de estos objetivos es el realizar una serie de publicaciones (previo aval de las instancias universitarias) que profundice en el terreno de la estética en torno a tres grandes pilares de esta área: Platón (Mímesis I), Aristóteles (Mimesis II) y Hegel (Mímesis III). De entrada, estos títulos pueden confundirse con las tres mímesis que Paul Ricoeur recoge y estudia en su texto Tiempo y Narración (1995). Se trata solo de una coincidencia ya que en nuestros textos no se desarrolla la línea hermenéutica propuesta por este autor en su afamado texto. En su lugar, el proyecto busca centrar el estudio de la estética en el ámbito de la expresión como elemento fundante del arte desde sus albores en la Grecia antigua como techne y mimesis, pasando por la modernidad como representación y proyectándose hacia la época actual como estética expresiva.

Esperamos que este texto sea un aporte no solo al interior de nuestra comunidad académica, sino también que contribuya con la formación estética en nuestra región y por qué no, en nuestra nación tan sedienta y necesitada de fundamentar su educación en las artes y humanidades como antídoto ante la anticultura del narcotráfico y la devastación del consumismo. 


\section{I. \\ Mimesis y el cuerpo bello (la percepción)}

Por: Leonardo Londoño López

El profesor Londoño actualmente se desempeña como docente de la Universidad Tecnológica de Pereira, trabaja con el Programa de Ciencias del Deporte y la Recreación en el área de Investigación y Desarrollo, enseñando en las asignaturas de Filosofía e Historia del Deporte y la Recreación, Epistemología de la Salud y Sociología del Deporte y la Recreación. Estudió Licenciatura en Filosofía en la Universidad Tecnológica de Pereira y una Maestría en Investigación en la Enseñanza y Aprendizaje de las Ciencias Sociales en la Universidad Internacional de Andalucía en Huelva-España. Interesado en la corporalidad y en la antropología del cuerpo para nuevos caminos de reflexión sobre la salud, el ocio, y el juego.

Resumen:El cuerpo bello, en la publicidad, ha sido un alejamiento del cuerpo expresivo en su vitalidad; el que sufre, el que padece, el que llora, el que sueña. Es un cuerpo que nace en un formato en blanco para ser adaptado debido al ritmo contemporáneo de la industria del consumo. Y lo que se define como Bello es volátil, arrastrando así el término de Amor. Hacer un estudio sobre el sentido de la mimesis, es recuperar el sentido griego de lo que es el representar, ya que en ese acto del imitar no se suprime el acto creador del sujeto cuando se expresa. Ese acto, trae consigo la discusión filosófica de la relación sujeto y objeto, de persona y mundo, por lo que debemos, además de todo lo anterior, preguntarnos sobre ¿qué es la percepción y qué implicación tiene para el sentido de la belleza corporal? Encontrando como nuevo sentido para esta recuperación del valor de la percepción de la belleza, la encarnación, al estar emparentada, no en lo etimológico, sino desde lo filosófico con el acto poético.

La Naturaleza nunca se acuerda, y por eso es bella.

Pessoa 


\section{Introducción}

La pretensión de revisar la percepción en obras como el Teeteto o en El Banquete de Platón es para relacionarla con lo que nos pasa ahora: el cuerpo obsesionado en una forma de belleza estandarizada. La pregunta que ha girado a lo largo de las lecturas es si al conocer la explicación de Sócrates de por qué la percepción no es de por sí el saber de la verdad, permitiría identificar alguna causa de la transgresión de la belleza en la estética del cuerpo gracias a la publicidad ${ }^{1}$. Podría entonces suponerse que el problema se debe al seguir una imagen, 'de querer ser como', pero en realidad lo característico de nuestra cultura occidental es el de seguir un modelo, el de repetir un paradigma, es decir, el ser representado, el servirse de una imagen. En otras palabras, reconociendo que existe un abuso en seguir una imagen de 'cuerpo bello', 'cuerpo perfecto' en nuestro presente, no se trata de advertir en el imitar un acto negativo, sino que al construirse una especie de "objetividad pública", en una banalización del cuerpo, suprime al sujeto en su acto natural de crear y recrear lo que lo entusiasma así sea en una representación ${ }^{2}$. Así, si la mimesis es adecuada (como era la de los griegos) ¿qué tipo de imagen de cuerpo bello o cómo entenderlo sin ser este uno que ya esté arraigado en la cultura del marketing, o qué papel juega la percepción para el rescate de un sujeto que es reactivo y no pasivo en su experiencia de vivenciarse en el acto mismo de la creación? Lamentablemente, con la invasión publicitaria en la ciudad, en el hogar, la imagen de un cuerpo bello es externa, objetiva (entendida esta como algo intersubjetivo), casi impuesta, arruinando cada vez con esa idealización en la que se creía que la belleza está en el "mostrarse uno mismo" al crear-se y recrear-se $\mathrm{s}^{3}$.

La dificultad de dicha empresa, es demostrar la importancia de lo perceptivo en la

\footnotetext{
1. Es de suma importancia volver a estudios sobre la violencia encubierta como es la de Mario Margulis en su investigación publicada bajo el rótulo La Segregación Negada, en el que advierte, en el año 1999, algo que aun hoy orbita en nuestro medio: una modulación de cuerpo estandarizado violentando la imagen propia del sujeto que posee y hereda una cultura.
}

2. Sibilia, P. La intimidad como espectáculo. Buenos Aires. Fondo de Cultura Económica. 2009.

3. Londoño, L. El cuerpo retirado: reconstrucción para una acción política. Medellín. Fonámbulos. 2013. 
problemática contemporánea de la imagen del cuerpo bello, articulando el análisis socrático de dicho concepto y a la vez asumir la preocupación de la percepción tal como se presenta en la obra de Merleau Ponty y que esta surge precisamente para superar las conclusiones de la obra de Husserl para quien estas se habían convertido en mera metafísica. Lo sano sería no expandirse aquí haciendo una descripción que diferencie una percepción socrática de otra con formación fenomenológica, sino tener en cuenta el sentido contemporáneo para comprender la relación entre la percepción y lo objetivo y así, hacerle un análisis con el concepto de real a partir de la mimesis de Platón.

\section{El feo Teeteto}

Se nace feo o se es bello. ¿Pero quién asume que se ha nacido feo y luego poder ser bello? Platón hace una gran obra maestra en el diálogo del Teeteto, pensando en cada detalle, dándole sentido a cada parte como una obra pictórica del Renacimiento. El personaje de Teeteto físicamente es feo, igual que Sócrates, tal como el geómetra Teodoro (quien sabe sobre la simetría de las formas, de las proporciones) los ha calificado: desproporcionados en la forma de la nariz y con ojos prominentes (143e). Por ese saber que Teodoro posee, hace semejanzas, relaciones, y determina quién nace feo y cuáles son sus propiedades en un rostro.

Pero esos detalles no paran allí en la obra platónica del Teeteto. Anuncia que el problema de las semejanzas es materia del pintor, de la pintura, quien hace una representación de lo real. Y es él quien tiene ese saber. Para hacer dicha comparación, debe a la vez saber la naturaleza misma, mostrarse la cosa como es, como le pide Sócrates a Teeteto "mostrarte a ti mismo" y ahí sí determinar las semejanzas. Mostrarse a sí mismo no porque su cuerpo no representa lo que él es, sino que sea él quien se muestre, se proyecte, se exprese, sin valerse de una comparación externa, no propia de alguien que así tenga un saber "adecuado" sobre las proporciones no sería el indicado para uno saber quién se es.

En la actualidad, una persona es constantemente bombardeada sobre cómo vestirse, mostrándole el modo adecuado para identificarse en un presente cambiante como son las exhibiciones de las modas. Es un modo de despotismo psicológico, en el que se impone un "sentido" de los colores, afirmando que usarlo en un pantalón o en una chaqueta indica que el sujeto demuestra una cierta personalidad. En otras palabras, es la moda quien indica el carácter, la personalidad cuando una persona se viste. Eso es no mostrarse a sí mismo, como le exige Sócrates a Teeteto en miras de superar las determinaciones de un "conocedor de las proporciones" como es Teodoro, quien intenta describirlo, sino el de ocultarnos a nosotros mismos a través de una moda atractiva. 
Ese despotismo, ofrece la óptica de la imagen. Contradictoria además. Desde sus galas discursivas anuncia que toda aquella persona puede ser bien vestida, identificarse con un tipo de diseño o moda para hacer relucir sus mejores cualidades físicas y "mostrarse bello". Belleza que no está en el mostrarse uno mismo como uno es, sino el hacer parte de un estilo, de una vestimenta, es decir, el de mostrar. Estilo además que es primero exhibido por cuerpos prototipo de la moda, por medio de la pasarela, forzando un tipo de imagen correspondiente a un cuerpo para vestirse. Así que la imagen por medio de un traje representaría la buena compostura del sujeto; la apariencia es la que ofrece el sentido de la belleza; y al 'parecer' esa imagen, aparenta esa belleza. Es un retroceso a lo que Gadamer anunciaba del sentido bildung al permitir que en la formación no quedara reducido a una imagen imitada sin el proceso dinamizador del proceso. ${ }^{4}$ Lo anterior hace recordar lo que le decía Sócrates a Alcibíades, hombre además bello físicamente, "lo que intentas es adquirir algo que es bello de verdad a trueque de lo que es bello en apariencia", que, en otras palabras, dicha verdad es la de mostrarse uno mismo y así comenzar el camino de la visión del bien. Una visión de la inteligencia, no por medio de una obsesión de las formas, de los colores, "la vista de la inteligencia comienza a ver agudamente cuando comienza a cesar en su vigor la de los ojos, y tú todavía te encuentras lejos de esto"6.

Zandra Pedraza, en su obra En cuerpo y alma: Visiones del progreso y de la felicidad, identifica un tipo de discurso que condiciona un tipo de belleza que determina las proporciones adecuadas para una postura bella de la mujer ${ }^{7}$. Este discurso caligénico, negaba la fealdad de las mujeres, logrando la belleza por medio de los sentidos, es decir, debía impresionar, por ser una expresión material de la belleza, lo cual ya esa belleza no provenía del alma, que, en tiempos actuales, y sin salirnos de la lectura de El Banquete de Platón, es una belleza que provocaba.

Sócrates de nuevo nos da una lección. Podríamos imaginar que diría lo siguiente: "Teeteto, nos han llamado feos bajo una impresión de los sentidos, pero te diré que la imagen, la representación de la belleza comienza en el mostrarse, no en una que está capturada, rígida en un retrato, sino en su potencialidad, en su movimiento dialéctico". Alcibíades es esa lección. Creía este 'amado' que con solo mostrar su belleza física de por sí provocaba la atención de su amante, pero una

\footnotetext{
4. Gadamer, H. Verdad y Método. Salamanca. Ediciones Sígueme. 2005. Pág 40.

5. Platón. Banquete. Barcelona. Orbis S. A. 1983. Pág 105.

6. Ibíd. pág 106.

7. Pedraza, Gómez Zandra. En cuerpo y alma. Visiones del progreso y la felicidad. Bogotá. Departamento de Antropología. Universidad de los Andes. 1999. pág. 304-305
} 
cosa es el mostrar belleza, el tenerla, y otra muy diferente es esa fuerza con la que una persona se muestra a sí mismo. De ahí que sea el Amor feo físicamente, necesitado y no se deja influenciar por ningún discurso caligénico de la belleza.

\section{El amor no es bello}

Cuando se espera definir al amor, como suele pasar en cualquier intento de definiciones, es poco lo que se dice en realidad, porque cada atribución es pronunciada a la ligera, sin una previa revisión de su veracidad. Pero ¿en el fondo esto qué quiere decir? La publicidad es como un parásito que sin una forma definida, ha dado una multiplicidad de imágenes influyendo al hospedante en cada concepción del amor y de lo bello. Aunque, en la actualidad, hablar de certeza no es apropiado, y mucho más en relación a qué es en verdad el amor o en caso específico, qué es la belleza, la pregunta apunta a lo siguiente: ¿entonces todo está perdido en cuanto al pronunciamiento? ¿El amor y lo bello será una cuestión inefable por el abuso subliminal de la imagen publicitaria? ¿Y acaso con imaginar una imagen sin decirla no sería ya un vector de dicho comensal en un nuevo huésped? Ya que cada palabra, cada anunciado, podría estar coordinado por el delirio provocado por el huésped; ¿no sería más que una fiebre el reflexionar filosófico defendiéndose de algo inevitable?

La proliferación del sentido de belleza en la moda sirve como ilustración para comprender aun más la convicción de Agatón sobre el amor. Según este poeta, el amor desea lo bello y es por ese mismo deseo que hace que el amor sea bello, por tender siempre a eso que desea. Cuando vemos que alguien se viste a partir de las últimas colecciones de la moda, cada verano, cada primavera, son lapsos para tender al buen vestir, es decir, vestir bello, por eso, según con la similitud del argumento de Agatón, la persona es bella al tender siempre a lo bello por medio de esos ciclos. Pero ¿no es verdad que el deseo anhela lo que no tiene? Porque es claro que no se desea algo que ya se tiene. Por tal motivo, de por sí el amor no es bello, debido a que anhela algo que no tiene, la belleza. Y es así en el buen vestir, porque no se viste a la moda porque se es bello, sino porque desea aquello que no tiene para sentirse, aprobarse como bello, que hoy, en términos actuales, se relacionaría con lo atractivo. Atraer a ese otro que busca, que anhela tener eso que no tiene: ese otro cuerpo que desea la aprobación de una imagen impulsada por la publicidad. Cuando alguien se interesa por alguna persona, está aprobándole el logro de alcanzar la representación de la belleza, pero es un interés aun en la plataforma de la publicidad, debido a que está condicionado sobre las proporciones de lo que es bello por la moda. Así, si se quitara toda esa proliferación, todo ese vestir, no quedaría más que el cuerpo desnudo, feo; según la coherencia de la moda. ¿Si alguien no se vistiera tendiendo a lo bello, entonces se participaría de lo feo? 


\section{El amor no es joven}

Hay un paralelo evidente con Agatón y el discurso de la moda actual, cuando este afirma que el amor es siempre joven porque, según él, es siempre bello. Ya, en el apartado anterior, se ha dicho que el amor no es bello, ahora hay que ver por qué el amor tampoco es joven.

Los cuerpos modelo representan un cuerpo joven, intentando quedarse suspendidos por fuera del tiempo devorador e incinerador de la vida. El amor "entre los jóvenes siempre anda y está, pues razón tiene ese antiguo dicho de que lo semejante se arrima siempre a lo semejante" 8 . Y ese andar, y ese habitar no es intelectual, ya que la inteligencia es dura, rígida, adquirida durante el tiempo, mientras el amor es delicado, habitando en la parte blanda del ser humano. Así, ese amor no mora sin exclusión en todas las personas, sino en las de carácter blando, flexible. Y es de ese modo en particular que se ha servido la publicidad para crear una necesidad de consumo, repitiendo bajo patrones de comportamiento para ofrecer la ilusión de alcanzar la felicidad. Una forma atemporal pero flexible, cambiante, no rígida; al ofrecer la "opción voluntaria" de una creación más, pero todas enmarcadas en la categoría de reflejar la forma de un cuerpo joven y fresco. Cada quien se siente libre de vestirse, de combinar diferentes colecciones, de inspirase creativamente, afirmándose en el espejismo de que la belleza es una construcción subjetiva al no tener una forma rígida, exacta, pero es una flexibilidad revestida, movida por un despliegue de la publicidad, porque lo que han hecho los medios es convertir el cuerpo como una imagen que se media-tiza, es decir, hace del cuerpo mismo un medio para trasmitir la imagen?.

Total que, ese modo de ver el amor y su relación con la belleza como algo blando, sin carácter, el acto de crear pasa a ser un medio para que el ser humano permanezca en ese espejismo de poseer el amor y la belleza, supuestamente porque se ha superado la dependencia a una necesidad de supervivencia, ya que no hacía más que obligarlo a moverse y actuar de acuerdo a las exigencias de la naturaleza, mientras que el amor y el deseo a lo bello alcanza la libertad y no cae en una destrucción, obteniendo como recompensa la paz y el bienestar: "nos procura mansedumbre, nos despoja de rudeza; amigo de dar benevolencia, jamás de malevolencia, es benigno en su bondad (...) envidiable para los que no lo poseen, digno de ser poseído por los favorecidos

8. Platón. op. Cit. pág. 65.

9. Beltin, H. Antropología de la Imagen. Madrid. Katz Editores. 2007. pág. 17 
por la suerte"10. Pero esa separación, ese no estar atado a la necesidad, hace ver hoy otra dependencia a la forma cambiante de la belleza estandarizada constantemente por la publicidad, porque va generando ese deseo al sujeto ante determinaciones de lo bello ${ }^{11}$. Y así alguien pretenda crear otra expresión, representar algo por fuera de la belleza publicitada, quedaría la sospecha de asegurar si dicha nueva imagen no proviene de una persona 'ablandada' por el entorno.

Ahora bien, ¿es acaso inadecuado relacionar el amor con la necesidad? ¿Solo el amor puede ser visto en relación a la libertad? Al incluir en toda esta discusión al amor es para asumirla como esa fuerza, esa conexión con ese otro ser que no soy yo; ese deseo de estar con el otro y en él sin suprimirme a mí mismo; vivencia dialéctica en el que se encuentran dos seres distintos pero en el que en cada acto de creación representa ese todo compuesto y distinto.

Diotima, que es la sacerdotisa que cautiva a Sócrates sobre el discurso del amor, sostiene que el amor no es feo así desee eso que no tiene: la belleza. Por ejemplo, si una persona no nace o va adquiriendo las cualidades de belleza que insistentemente se repiten como imagen en la televisión, en el cine, en las revistas, etc., ¿esa persona se consideraría fea? El sentido común respondería sin duda que sí. El asunto, visto así, obliga a reiterar la pregunta convencional ¿qué es la belleza? Y si llegara a definirse, cómo se garantizaría que no hace parte de la influyente imagen publicitaria globalizada; cómo asegurar que no es otro revestimiento. Talvez, a fin de cuentas, no se trata de obsesionarse por cada gesto, postura o acto intentando que no sea en el fondo influido por el mundo globalizado, sino, como antes se había dicho, "mostrarse a sí mismo". Cuando Diotima le dice a Sócrates que el amor no es feo, ni malo al no poseer la belleza, sino que hay un término medio, sería interesante dedicarse en otra ocasión a un análisis sobre si dicho intermedio podría entenderse con la actual expresión fenomenológica "poner entre paréntesis". Pero por razón de orden, lo que aquí debemos analizar es si esta interfase permite mayores aclaraciones de la percepción. Lo primero a aclarar, es que ese intermedio es diferente a ese estado en el que cae el sujeto que no hace más que repetir una forma flexible de belleza pero condicionada, porque es un intermedio que es un daimon, un ser activo y no que sea el sujeto un medio en el que se alimenta la publicidad para seguir con su "naturaleza": cambiante.

10. Ibíd. pág. 69

11. Es interesante acercarse a los estudios neurológicos de Cordelia Fine, que a diferencia de otros estudios en la biología, enfatiza sobre la influencia del entorno en el desarrollo de conciencia del individuo, en el que hasta podría influir en la conciencia de género. Parece ser más una convicción social que una de orden natural. Para mayor información, existe la página oficial http://www.cordeliafine.com/ [citado en 24 de agosto de 2012] o varias videoconferencias en la que se sugiere una revisión ética a la influencia de la publicidad en nuestra mente. 


\section{Uno no se hace genio, "le nace"}

Nacer no de neonato, es decir, de nacimiento de un ser bajo el bello proceso de gestación, sino de lo espontáneo: fuerza, empuje que transforma, crea y recrea lo anteriormente creado para verlo de nuevo en otra forma, en otra dirección, en otra intención. El amor para Diotima, es un genio, un daimon, el enlace entre ese mortal que ama y lo divino amado: "en ella, dos mundos distintos y distantes se ponen en contacto y lo inaccesible se hace presente" 12 . Y esa fuerza, ese genio, de por sí no es bello, ni bueno, porque de no carecer la belleza no sentiría el deseo de necesitarlos, y es por tal motivo que el amor está en relación a la necesidad. Esta salvedad, pone una gran responsabilidad al necesitado, que al no poseer ni la belleza ni la bondad, tiene, no obstante, la genialidad de vivirlas, de intentar alcanzarla no para buscar obtener el parecido, tal como sucede en la representación de la imagen de belleza que ofrece el mercado por medio de la publicidad, sino que la "mimesis afirma la identidad en la diferencia, sin que esta diferencia empírica sea sustancialmente transformada de modo necesario (...) sin que obligadamente se busque el parecido"13. Si fuera al revés, debería asumirse la belleza para atraer al semejante evidenciándose lo que ahora sucede: la belleza agotada en una imagen quieta, modelada, que se exhibe y obliga, es decir, se impone, que al conquistarla es para tenerla, adquirirla, como un auto, como el mejor vestido de boutique para clientes distinguidos. Es una imposición desde el exterior sin ser un constructo del sujeto, negando la posibilidad de una creación para representar el sentir que ese amado o amada inspira, rompiendo las normas de lo cotidiano. En cambio con la belleza estandarizada, objetiva en el sentido intersubjetivo que se alimenta por la publicidad, la creación es rutinaria, monótona. Así que, el amor al considerarse como esa fuerza que necesita, se es activo y no un reproductor de una forma establecida, estandarizada, sino procreador, que busca, que intenta conquistar por medio de sus habilidades, propiedades, fuerza propia. La reproducción se logra desde un movimiento mecánico, repetitivo; un sujeto biomecánico aplicando un esfuerzo al que se ha adaptado.

“Sabes que el concepto de 'creación' es algo muy amplio, ya que ciertamente todo lo que es causa de que algo, sea lo que sea, pase del no ser al ser es 'creación', de suerte que todas las actividades que entran en la esfera de todas las artes son creaciones y los artesanos de estas creadores o 'poetas"' 14 . Aunque no toda persona, como asegura Diotima, que crea se le llama poeta, como al artesano, pero su acto está familiarizado al pretender un nuevo ser. El procrear es un renacer. El procrear a otro ser gracias

12. Bozal, Valeriano. Mímesis: las imágenes y las cosas. Madrid. Visor. 1987. pág. 67.

13. Ibíd. pág. 70.

14. Platón. Op. Cit. pág. 83. 
a la unión de dos personas, es un ser que armoniza las cualidades buenas y bellas de las dos, potencializándolas, revitalizándolas en una nueva generación. Y aunque no nos llaman poetas por ser padres, se hace parte del acto de la creación al estar a favor de ella y renacer a un ser bello, no porque sea amor a la belleza, sino amor a la generación, a la continuidad, al renacer.

"Pero no puede procrear en lo feo, sino tan solo en lo bello"15 " En cambio, cuando se aproxima a un ser feo, su rostro se empobrece, se contrae entristecido en sí mismo, se aparta, se repliega y no procrea, sino que retiene dolorosamente el fruto de su fecundidad" 16 ¿ ¿O sea que desde un texto tan antiguo se defiende la importancia de amar lo físico, lo bello en la apariencia? Si fuera bajo el sentido del reproducir, tal vez así debería entenderse El Banquete de Platón. Pero el pro-crear, el estar a favor de la creación, se emparenta con el sentido de salud, en el que la generación logra inmortalizarse en el acto de la creación, que más que lograr esa representación física es mantener esa vitalidad de seguir creando, transformando.

Pese a lo anterior, en el presente habita una mayor fuerza de adaptación, en el que el cuerpo debe representar la figura estandarizada: delgada, sin actividad física, pálido, sin disciplina en educación física, en otras palabras, enfermo. Lo enfermo no es ni bello ni bueno, y no es un término medio entre la fealdad y la belleza. Lo enfermo es feo ante el sentido de la procreación, de la generación. Lo lamentable es que ante tanta artificialidad, es esto lo que hoy se reproduce: cuerpos decorativos. Como cuerpos sin rostro, cuerpos sin forma, servidos para repetir lo que la sociedad le impone en ese formato virgen.

En cada formato, en cada representación de esa belleza externa, pierde la oportunidad de una explosión de sentidos, de renacer sus cualidades propias, aventurarse a descubrirse, a mostrarse a sí mismo. En cada dependencia a un vestir, a un ser a partir de esa imagen reproducida, se va deshabitando esa fuerza, esa espontaneidad en el que permite nacer cada creación, expresión de una identidad que no está obligada a parecerse a nada pero que puede servirse de algo para superarla, transformarla, entenderla, acercarla o hasta encarnarla.

\section{El sentido de la percepción}

El sentido común ha definido reiteradamente sobre la belleza lo siguiente: "es relativa, cada quien considera qué es bello o qué no lo es, de acuerdo a sus gustos". Es sospechosa esta afirmación desde el punto de vista de la invasión de las imágenes

15. Ibíd. pág. 85 .

16. Ibíd. pág. 86 . 
publicitarias, lo cual, sin embargo, le da más derecho a la publicidad el seguir ejerciendo su poder ante el consumidor, responsabilizando que es el sujeto quien tiene un gusto propio por lo que quiere comprar y verse a sí mismo, mostrarse como mejor desee. Por eso, de acuerdo a lo anterior, es justo revisar qué es lo que se entiende por objeto, y por qué la pregunta de si se puede lograr una objetividad involucra el sentido de belleza y con él la percepción.

Hay que ser cauteloso al asumir la percepción en un discurso en relación a la representación de la belleza, debido a que este primero ha estado presente a lo largo de la ontología filosófica y puede tender a dispersarnos. Por eso, lo crucial en este análisis es saber si el modo como define Sócrates en su diálogo con Teeteto es solo una teoría entendida como intelectualismo o idealismo, o si antes tiene una mirada contemporánea y que puede relacionarse con el cuerpo bello.

La percepción no es el camino -apoyándonos en la teoría platónica del Teeteto- para definir o llegar a la verdad de las cosas. Pero a lo largo de las teorías epistemológicas en occidente, se ha discutido qué función o cómo procede la percepción. La razón de preocuparse por ella es para acercarse a definir lo que es la objetividad.

En otras palabras, el empirismo, como corriente filosófica, definela función perceptiva del ser humano de acuerdo a su concepción de objetividad, lo cual va en contra vía a la del idealismo, que al ser diferente a la del empirismo no obstante se preocupa por comprender la percepción misma. El empirismo, por ejemplo, asume la percepción como el registro del objeto por medio de los sentidos, ofreciendo el valor de verdad, el cual depende del grado de mostración de la realidad misma del objeto ${ }^{17}$, en el que depende de una intersubjetividad, es decir, "un valor de verdad realizado por un reconocimiento universal de muchos observadores" ${ }^{\prime 1}$. En cuanto al idealismo, considera que el valor de verdad no es auténticamente real así sea constatado por varios observadores, debido a que cada uno de ellos posee un pensamiento que actúa en la representación del objeto, o sea, objeto es siempre objeto de pensamiento.

Porque una gran masificación considere que la belleza física sea tener un cuerpo 'enfermo', no por ello se debe asumir que es la objetividad de belleza en su auténtica realidad. He ahí la importancia de la percepción, ya que es esta el intermediario entre un sujeto que tiene ideas, pensamientos, y un objeto que está fuera de ese sujeto. Por lo tanto, saber lo bello, explicar la belleza, depende de lo que se entiende por perceptivo, debido a que actúa allí, o mejor, juega allí, una relación de un sujeto que contempla y aprecia no por lo ofrecido, estipulado, sino eso que hay en mí

17. Cfr. Arias Muñoz, Adolfo. La antropología fenomenológica de M. Merleau-Ponty. Madrid. Fragua. 1975. pág.145.

18 Ibíd. pág. 144. 
que configura eso que aprecio fuera de mí sin reducirlo solo a una intencionalidad personal mía, y el diálogo de intersubjetividades que posibilita el o la artista. Por lo pronto, la superación que justifica el idealismo al empirismo es reconocer que en lo perceptivo el sujeto ordena los datos que recibe de los sentidos.

En relación con lo anterior y teniendo en cuenta al Teeteto, dicho orden alcanzado, es decir, el de organizar los datos que recibe de los sentidos, no es suficiente para saber auténticamente lo real, debido a que la realidad parece constituirse como un constante devenir (flujo y movimiento) "según el cual nada es, sino que está siempre en proceso de llegar a ser, ya se trate de lo bueno, de lo bello..." ${ }^{19}$, el cual la percepción registra algo que es o no puede ser, siendo, el sujeto, entonces, la "medida de todas las cosas".

Así que, con las palabras de Sócrates en el Teeteto: ¿si hoy el esquema de belleza del cuerpo humano es uno delgado, sin fuerza, pálido, hay que aceptarlo debido a que es una medida, una consideración del ser humano que hoy le da un sentido útil al expresarlo? Afirmar la pregunta, no habría modo alguno de saber lo que es la belleza del cuerpo, y no habrá determinación alguna que permita saber si el cuerpo "bello" impulsado por la imagen publicitaria perjudica más al sujeto antes de beneficiarlo, ya que todo puede estar en un proceso, en un movimiento para ser otra cosa. El riesgo de asumir tal realismo es valerse de lo que se considere útil para determinar la objetividad ${ }^{20}$, ya que lo perceptivo sería entonces algo particular de cada quien, cazando palabras para representar lo visto ${ }^{21}$, cayendo de nuevo a lo antes expuesto: lo bello es lo que cada quien asume. Lo perceptivo en la filosofía contemporánea es analizada para ofrecer otra vía al radicalismo del positivismo que la había asumido como ese proceso confiable de la objetividad de acuerdo a lo que experimento, cuando tiene más una relación directa con la intencionalidad que el sujeto vive cuando experimenta.

Pero, por otro lado, si la belleza del cuerpo en la actualidad es un reconocimiento de un cuerpo maniquí, debido a la influencia de los 'media' en la intersubjetividad, tendríamos, por lo tanto, que asumir dicho reconocimiento como algo objetivo, como algo verdadero. Lo cual en este análisis, lo rechazamos abiertamente. Y abiertamente rechaza Platón considerar que lo que se percibe en su entorno sea medidor de la verdad, porque sea útil el ser un dictador ante una sociedad violenta, no quiere decir entonces que sea este el camino verdadero para la justicia. Porque se imite el cuerpo

19. Platón. Teeteto. Madrid. Gredos. 1999. pág. 193

20. La utilidad del cuerpo bello sería entonces que si este cuerpo logra una imagen para ser reconocido y ser amado, entonces sirve, tiene sentido para mí.

21. Platón. Teeteto, Op. cit. pág. 224. 
bello de la publicidad para alcanzar un tipo de autoestima, no quiere decir que sea el camino adecuado para alcanzarla, por lo que hay que detenerse por un momento qué es esto del cuerpo bello.

Para alcanzar Platón una posible respuesta que permita superar la concepción de un sujeto maleable debido a lo que constantemente percibe, hay en el Teeteto una gran profundidad filosófica para responderla ${ }^{22}$, pero que aquí solo se refrescará con una palabra no tan desconocida pero sí tal vez subestimada: la reflexión. La belleza no se adquiere por los sentidos, nos dice Sócrates, sino por las características que conforman al objeto, y es el pensamiento que orienta, como la belleza, la fealdad, por una actividad reflexiva:

Los hombres y los animales, desde el momento del nacimiento, tienen por naturaleza la posibilidad de percibir todas aquellas impresiones que llegan al alma por medio del cuerpo. Pero las reflexiones acerca de éstas, en relación con su ser y utilidad, sólo sobreviven con dificultad y en el curso del tiempo. Y las personas que llegan a tenerlas sólo lo consiguen gracias a muchos esfuerzos y después de un largo periodo de formación ${ }^{23}$.

Mas la batalla se ha perdido: ya la reflexión acerca de lo bello, y en particular el cuerpo bello, se ha quedado en los artículos filosóficos, en las teorías y en la literatura, y lo filosófico para el sujeto televidente es para apasionados en el oficio, lo teórico un requisito académico y lo literario una técnica cultural. Lo publicitario ha tenido mayor peso, debido al fracaso hoy de lo educativo en la formación reflexiva, en el que la imagen del cuerpo "bello" es como un parásito que se apega a nuestra mente humana. En este caso, vale más una opinión que un saber, porque la publicidad es el sofista en la actualidad, ya que "por medio de su arte, persuaden, no enseñando, sino transmitiendo las opiniones que quieren" ${ }^{24}$.

Antes de alejarnos un poco del Teeteto, rescatamos el análisis de la percepción como una discusión de lo que es la realidad y la verdad, lo objetivo y el rol del sujeto en la experiencia con el mundo y, aun más, el rescate de la reflexión (tiempo y esfuerzo) para el saber de la belleza. Ahora, es importante discurrir si es posible pensar la función del reflexionar al de la percepción, porque ¿cómo estas interactúan asegurando una mutua participación en el que el sujeto sea un constructo, procreador de la belleza de su cuerpo?

22. Ibíd. pág. 264-268.

23. Ibíd. pág. 265.

24. Ibíd. pág. 295. 
Para Maurice Merleau-Ponty, hacer una revisión de la percepción permitiría recuperar lo cualitativo del sujeto en su construcción de sentido en el mundo que vive, debido a que lo perceptivo no solo tiene como labor organizar los datos de la experiencia, sino la implicación psicológica en esas relaciones de sentido en cada fenómeno: “(...) un fenómeno suscita a otro no por una eficacia objetiva, sino por el sentido que ofrece" 25 . Lo cual, las cualidades de un objeto, como la belleza de un cuerpo no es por una "inspección del espíritu", como si lograra sentidos aislados o separados de lo que percibe, porque este lo que hace no es solo descubrir el sentido que hace cada fenómeno, "sino que hacen que tengan un sentido" ${ }^{26}$ y más cuando es reforzado aceleradamente en un mundo mediático.

\section{La encarnación: el sentido de la percepción}

En consideración a todo lo anterior, de nuevo es necesario un despertar; darle sentido a un reflexionar sobre lo bello para recuperar al cuerpo, ya que este ha sido asumido por la publicidad como un objeto, en el que la intersubjetividad es guiado hacia una variedad de identidades superficiales en el lenguaje efímero de los slogans. Al cuerpo se le debe recuperar, verlo como carne; estar en la carne, es decir, un cuerpo que siente, que desea, que lucha, que encarna todo lo vivido mientras vive: percibe.

$\mathrm{Y}$ ese modo de reconocerme que no soy yo y mi cuerpo, sino que soy cuerpo (ese es el significado de lo encarnado) es en la experiencia del esfuerzo, del placer o del temor $^{27}$ en un tiempo y espacio cargado de sentido. Pero en la "cajita feliz" articulada por la lógica del consumo, en el rostro "reluciente" que regularmente se refuerza en la pantalla de televisión, no hay espacio para ese reconocimiento, el vivir la angustia de mí mismo en el esfuerzo, agotamiento, desasosiego de mi existencia.

Precisamente, se nota una lucha entre la estética corporal de la cirugía y la disciplina deportiva: en las dos actividades hay un cuerpo que se reconoce. En el primero se afirma un cuerpo modelo que intenta imitar al cuerpo atlético, es decir, reproducirlo, mientras que en el segundo se esfuerza el cuerpo en lo agonístico, a partir de una superación de sí mismo, requiriendo de un trabajo autónomo debido a que es una acción lúdica, logrando un reconocimiento de un cuerpo bello, porque vive las posibilidades, lo que puede ser, desear; y en ese goce, sufre y se apasiona, llora y ríe, grita; tensiona sus brazos representando vigor, recompensa por todo ese trabajo

25. Merlau-Ponty, Maurice. Fenomenología de la percepción. Citado por Arias. Op.cit. pág. 154.

26. Merlau-Ponty, Maurice. Fenomenología de la percepción. Barcelona. Planeta Agostini. 1985. pág. 58.

27. De ahí entenderíamos por qué para Ponty el conocimiento fisiológico (específicamente la del esfuerzo humano) y la psicología (particularmente la de la Gestalt) son conocimientos que ofrecerían respuestas a la relación entre el sujeto y el objeto. 
personal. Así que no reproduce una imagen envidiada, sino que procrea otra imagen, así sea inspirada en un héroe que ha encarnado el agotamiento, la pasión, las lágrimas de la impotencia, creando aun así, gracias a esa inspiración, otra forma, una nueva posibilidad; como ese hijo procreado por dos seres que intentan inmortalizarse por medio de otro ser que no son ellos mismos pero que habitan en él desde la fuerza de superación, de creación de sí mismo, no como fantasma de sus padres, sino como hijo: un ser nuevo procreado por otros seres admirados por sentir su cuerpo en el deseo.

No hay encarnación, si el sujeto entra en un juego discursivo en el que se siente dueño de su cuerpo porque lo decora, lo perfecciona ante una imagen deseada desde afuera, "argumentando" que aun así no interfiere en su identidad, en su personalidad por tales modificaciones. Porque cree que es diferente a ese cuerpo que habita. Pero no puedo evitar que la intencionalidad sea por una red de vivencias.

Se siente que soy cuerpo cuando sufro, tiemblo, padezco ante un miedo, porque esa vulnerabilidad a la vez permite el camino de reconocer la grandeza, de lo que puedo lograr ser, desde la creación, desde lo que vivo. Y se siente que soy cuerpo cuando mi recurso es mi esfuerzo, mi lucha, ese no dejarme vencer y sentir la victoria, el reconocerme como ganador por mi habilidad.

En un acto encarnado en el que el sujeto se conoce, se reconoce, porque él mismo crea, transforma, guiado por una imagen que lo ha procreado. Encarnar es el sentido original de mimesis ${ }^{28}$, debido a que voluntariamente quiere sentirse ese otro ser, ser otro sin abandonarse, inspirado, honrado, en un estado de fiesta, de ceremonia en el que el cuerpo es quien guía el sentido artístico de la creación. Por ejemplo, en el juego, se produce un cambio de personalidad, ya no se es lo que "comúnmente se es", pero que precisamente revela lo que en verdad uno es, como un carnaval sintiendo, por medio de la danza, la máscara, que encarna ese ser que estaba alejado del mundo serio, oficial; como procrearse uno mismo, exhibiendo sus cualidades, su confianza; estimándose a sí mismo. No es imitar simplemente, es encarnar. Ya no es "ser como...", se es, logrando efectos activos, creadores, dinámicos, en el que en esa vivencia no hay un afuera, un exterior, sino un espacio creado, poético.

28. Bozal. Op. cit. pág. 70. 


\section{Bibliografía}

Beltin, H. Antropología de la Imagen. Madrid. Katz Editores. 2007.

Bozal, V. Mimesis: las imágenes y las cosas. Madrid. Visor. 1987.

Gadamer, H. Verdad y Método. Salamanca. Ediciones Sígueme. 2005

Deleuze, G. Nietzsche y la Filosofía. Barcelona. Anagrama. 1971.

Gómez, Z. P. En cuerpo y alma. Visiones del progreso y de la feclicidad. Bogotá. Departamento de Antropología. Universidad de los Andes.1999.

Londoño, L. El cuerpo retirado: reconstrucción para una acción política. Medellín. Fonámbulos. 2013

Merleau-Ponty, M. Fenomenología de la percepción. Barcelona. Planeta Agostini. 1985

Muñoz, A. A. La antropología fenomenológica de M. Merleau-Ponty. Madrid. Fragua. 1975

Platón. Teeteto. Madrid. Gredos. 1999

Platón. El Banquete. Barcelona. Orbis S. A. 1983

Sibilia, P. La intimidad como espectáculo. Buenos Aires. Fondo de Cultura Económica, 2009. 


\section{II. \\ Mimesis y poesía enamorada. La poesía es solo de los enamorados}

Por: Jorge Armando Ardila Robledo.

El profesor Ardila es Licenciado en Filosofía (Octubre de 2009) de la Universidad Tecnológica de Pereira; su trabajo de grado se tituló: El Lógos de Heráclito-habla. Lógos - Légein. Es miembro activo del Grupo de investigación en Estética y Expresión. Actualmente es profesor nombrado de Ciencias Sociales adscrito a la Secretaría de Educación del municipio de Medellín, Colombia.

Resumen: Muchas veces hablamos del amor como si fuera un concepto universal, como si fuera entendido empleando un lenguaje común. De igual forma lo hacemos con la poesía, y ambos, amor y poesía, parecen guardar una relación muy particular. Este texto quiere indagar en esa relación, a través de lo que se manifiesta en los enamorados. ¿Quiénes son los enamorados? ¿De qué se enamoran? Y más concretamente, cómo se refleja la mimesis como representación de la poesía en ese estado de enamoramiento. Para intentar dar respuestas a estas preguntas nos apoyaremos en las visiones de Heráclito, de Éfeso, de Platón, y en algunos comentarios de Emilio Lledó y Angel Cappelletti.

La poesía sólo pertenece a los enamorados,

pues habla en el lenguaje de éstos, habla con el lenguaje de la locura.

En el presente texto queremos indagar el papel que juega la mimesis como representación en la poesía enamorada, y más concretamente cómo se refleja esta representación de la poesía en quienes están absortos y encantados con la locura del amor. Es evidente y muy cierto que cualquier persona puede leer poesía con sus propios ojos a menos que los tenga físicamente imposibilitados para ver debido a algún daño en ellos. Y también es evidente que no todos aquellos que pueden leer poesía están enamorados, y muchos dirán, además, que la poesía habla sobre variados temas y no exclusivamente sobre el amor. Pero la tesis que pretendemos exponer en este artículo es que la poesía verdaderamente solo está dirigida a los 
enamorados, y solo ellos la pueden verdaderamente leer. Ahora, tenemos que dar por sentado de una manera inamovible que la poesía solo puede ser escrita también por seres poseídos por la locura del amor. Está escrita en códigos que solo los enamorados pueden entender. Escrita por enamorados para enamorados. Es por eso que un poema de amor escrito con enorme pasión por alguien que se encuentre poseído por Eros logrará su cometido siempre y cuando caiga en manos de otro ser que se encuentre en similares condiciones, de lo contrario dicho poema tendrá una alta posibilidad de estar condenado al olvido o a la muerte.

Decir que la poesía es solo de los enamorados podría querer decir también que todos esos temas de los que habla la poesía confluyen en el amor, o en otras palabras, que todos ellos serían abarcables a partir del concepto del amor. Así, si un poema hablase sobre la angustia, sobre la cólera, sobre la ironía, la rabia, el dolor, el olvido, la ausencia, el perdón, la tristeza, la melancolía, la depresión, la felicidad, la guerra, el odio, la muerte, la vida, la naturaleza, etc., en últimas, tal poema estaría hablando sobre el amor. Incluso esos términos que parecen opuestos y contradictorios discurrirían sobre este concepto. Luego tocaremos este punto analizándolo según la caracterización que le demos a los enamorados, y traeremos a colación a Heráclito quien nos hablará acerca de los opuestos diciendo que estos son uno solo.

La cuestión que nos exige ahora ser examinada es la de especificar el concepto del amor, de tal manera que este corresponda con la representación que queremos hacer de la poesía. También nos abordan otras preguntas: cómo son los enamorados, qué es lo que representan, quiénes son y de qué se enamoran.

Para poder establecer esa relación de la poesía con el amor, vamos a exponer primero una interpretación filosófica del Eros desde el punto de vista platónico; esto nos ayudará a marcar una diferencia entre el amor desde la filosofía y el amor desde lo poético, siendo este último el que nos interesa investigar.

Antes de responder a las preguntas sobre los enamorados, es necesario indagar otras preguntas, así como lo hace Sócrates: ¿Es por su naturaleza el Amor de tal clase que sea amor de algo o de nada? Debe ser amor de algo, y ese algo ¿será aquello de lo que está falto? Si es de aquello de lo que está falto, entonces, el Amor, considerado como amor de la belleza, debería carecer de ella; y, como las cosas buenas son bellas, el Amor estará falto también de las cosas buenas. Estas son algunas de las preguntas que resaltan al inicio del diálogo entre Diotima y Sócrates en El Banquete. Se dice pues que el Amor no es bello ni bueno. Pero tampoco es feo ni malo, sino que es algo intermedio entre los dos extremos. De igual forma, tampoco es un dios, puesto que los dioses son bienaventurados por poseer las cosas bellas y buenas, sino que es un gran genio, es decir, está entre lo divino y lo mortal. Eros es el dios mediador, transmite a los dioses las cosas humanas y a los hombres las cosas divinas. Es hijo de 
Poro (el Recurso) y Penía (la Pobreza).

En primer lugar es siempre pobre y está muy lejos de ser delicado y bello, por el contrario, es rudo y escuálido, anda descalzo y carece de hogar, duerme siempre en el suelo y sin lecho, [...] pues por tener la condición de su madre, es siempre compañero inseparable de la pobreza. Mas por otra parte, según la condición de su padre, acecha a los bellos y a los buenos, es valeroso, intrépido y diligente; cazador temible, que siempre urde alguna trama; es apasionado por la sabiduría y fértil en recursos: filosofa a lo largo de toda su vida y es un charlatán terrible, un embelesador $y$ un sofista. ${ }^{29}$

Eros se encuentra en el término medio entre la sabiduría y la ignorancia, entre lo inmortal y lo mortal. De aquí podemos inferir la respuesta de por qué la filosofía es erótica. Habiendo dicho que Eros no es un dios, puesto que los dioses ni filosofan ni desean hacerse sabios (porque ya lo son), y que tampoco participa de la ignorancia porque los ignorantes, al creer que no están faltos de nada, no sienten deseo de lo que no creen necesitar, se encuentra entonces en el intermedio, allí mismo donde está la filosofía. "Pues es la sabiduría una de las cosas más bellas y el Amor es amor respecto de lo bello, de suerte que es necesario que el Amor sea filósofo y, por ser filósofo, algo intermedio entre el sabio y el ignorante"30. Esta es pues la naturaleza de Eros, él tiene la palabra mediadora entre los dioses y los hombres, no es un hombre que de todo carece ni es un dios que todo lo posee; es un filósofo, porque desea y busca la sabiduría, por eso toda su vida es un filosofar, por eso la filosofía es erótica.

Esta estrecha relación entre el filósofo y el amor que nos presenta El Banquete de Platón, nos conduce, desde el discurso de Diotima, hacia un ascenso en la concepción del amor, que va desde lo más terrenal hacia lo más sublime. Este tema lo estudia Pierre Hadot en su texto ¿Qué es la filosofía antigua?, nos dice:

La emoción amorosa que el alma siente ante tan bello cuerpo es provocada por el recuerdo inconsciente de la visión que tuvo de la belleza trascendente en su existencia anterior (Fedro, 249b y ss). Cuando el alma experimenta el más humilde amor terrestre, es esta belleza trascendente la que la atrae. Aquí encontramos el estado del filósofo del que hablaba el Banquete, estado de extrañeza, de contradicción, de desequilibrio interior, pues el

29. Platón. El Banquete. 203B.

30. Ibid, 204B. 
que ama está desgarrado entre su deseo de unirse carnalmente al objeto amado y su impulso hacia la belleza trascendente que lo atrae a través del objeto amado. El filósofo se esforzará pues por sublimar su amor, intentando mejorar el objeto de su amor (Fedro, 253a).

Su amor, como lo dice el Banquete (Banquete, 209 b-c), le dará esa fecundidad espiritual que se manifestará en la práctica del discurso filosófico. ${ }^{31}$

Este punto de vista platónico acerca del Amor, aparentemente, nos podría separar de la interpretación que queremos expresar en la relación poesía- amor en su sentido más común, hablando de los enamorados que están salidos de sí mismos, de aquellos que se entregan uno al otro incondicionalmente, que hacen pactos de amor y que se olvidan y se abstraen de lo que los rodea, incluso de los mayores peligros, luchando $\mathrm{y}$ defendiendo lo que sienten contra todo aquello que amenace con destruir el amor que los embriaga.

Queda pues definida la caracterización de cómo son los enamorados que queremos vincular con la naturaleza de la poesía; ellos representan la imagen de lo romántico como la expresamos anteriormente, y se enamoran sencillamente el uno del otro. Con esto que decimos acerca del amor, podríamos pensar que los enamorados tienden a leer todo con el lenguaje del amor, incluso poemas que, a los ojos de otros, versen sobre cuestiones completamente distintas a este sentimiento. En tal caso, el título de nuestro texto ( $L a$ poesía es solo de los enamorados), tendría una validez universal para la relación de las palabras poesía-amor si hablamos en estos términos.

Las pasiones se muestran desenfrenadas en los enamorados, el arrojo a las pasiones y a los sentimientos es lo que los hace cada vez más humanos, más sensibles, más eróticos, y tal vez, menos lógicos, menos racionales, más locos, menos prevenidos, más extrovertidos, menos egoístas, y fundamentalmente, más salidos de sí.

Para contraponer esta idea, una primera lectura del pensamiento platónico, apoyándonos en el diálogo el Fedro, plantearía un volver a reunirnos con la divinidad, un elevarnos por encima de las pasiones, un ascender hacia lo divino, y para ello se necesitaría de la filosofía. Sin embargo, una segunda lectura al pensamiento platónico en este diálogo vislumbra una relación importantísima entre el amor, la 'manía' y la poesía:

31. Hadot, Pierre. ¿Qué es la filosofía antigua? México. Fondo de Cultura Económica. 1998. pp. 82 -83. 
Aquel, pues, que sin la locura de las musas acude a las puertas de la poesía, persuadido de que, como por arte, va a hacerse un verdadero poeta, lo será imperfeco, y la obra que sea capaz de crear, estando en su sano juicio, quedará eclipsada por la de los inspirados y posesos. Todas estas cosas y muchas más te puedo contar sobre las bellas obras de los que se han hecho 'maniáticos' en manos de los dioses. Así pues, no tenemos por qué asustarnos, ni dejarnos conturbar por palabras que nos angustien al afirmar que hay que preferir al amigo sensato y no al insensato. Pero, además, que se alce con la victoria, si prueba, encima, eso de que el amor no ha sido enviado por los dioses para traer beneficios al amante o al amado. Sin embargo, lo que nosotros, por nuestra parte, tenemos que probar es lo contrario, o sea que tal 'manía' nos es dada por los dioses para nuestra mayor fortuna ${ }^{32}$.

Este apartado del Fedro nos sirve para sustentar, en cierta medida, nuestro epígrafe, al mostrar que el poeta al momento de escribir su poesía debe de haber caído en un estado fuera de sí, que lo lleve a representar su poema con un cierto grado de manía o de locura. Y precisamente esta 'manía' es la del amor. Siguiendo esta idea, encontramos un parentesco con la opinión común que dice que el enamorado está loco, está salido de sí mismo y ha perdido un poco su razón. Más adelante retomaremos esta idea para llegar a algunas conclusiones y para establecer mejor el papel que juega la mimesis como representación en la poesía enamorada. Por ahora digamos que la característica fundamental del enamorado es la manía, su delirio y su locura. "Al partícipe de esta manía, al amante de los bellos, se le llama enamorado" 33 .

Ahora, si hemos de hablar de lo 'bello' en Platón, este tema nos conduce por fuerza a otro punto. Lo 'bello' va de la mano de lo 'bueno'; esto es: la kalokagathía. La belleza esencial que se vislumbra en los diálogos platónicos es la belleza del alma; el elevarnos por encima de las pasiones sugiere sobrepasar el impulso erótico que termina en el cuerpo para dirigirnos a la belleza del alma. "Así pues, si es una vida ordenada y a la filosofía a lo que los conduce la victoria de lo mejor que hay en el alma, pasan esta vida en la dicha y la armonía, puesto que, gracias a su dominio de sí mismos y su moderación, han sometido a lo que producía el vicio del alma y dado libertad a lo que producía su virtud." ${ }^{4}$ Se trata pues de orientar la vida hacia el amor a los discursos filosóficos. En este sentido, también podemos interpretar el diálogo Lysis o

32. Platón. Fedro. 244 e.

33. Ibíd 249 e.

34. Ibíd, 256 b. 
de la amistad, donde Sócrates expone que lo conveniente debe ser el objeto del amor, de la amistad y del deseo, y lo que conviene es lo bueno, es decir, el Bien.

Muchos filósofos se han opuesto tajantemente a estos argumentos platónicos, siendo Nietzsche el más destacado, pues ataca estas teorías al decir que son ellas las que precisamente atentan contra la vida. Se trata, desde esta otra orilla, de enmarcar al amor en los términos no racionales, en el campo de las pasiones, de la insensatez y de la locura. El enamorado tendrá entonces un lógos que se aparta de lo común, tendrá un lógos particular. Para argumentar esta idea llamaremos a Heráclito en lo que sigue.

La primera sentencia de Heráclito comienza diciendo: "Aunque este Logos existe siempre, los hombres se tornan incapaces de comprenderlo, tanto antes de oírlo, como una vez que lo han oído". Estas palabras nos permiten ver dos cosas, por una parte la eternidad del logos, y por otra, la incapacidad de los hombres para abrirse al logos. Los hombres, en su mayor parte, permanecen encerrados en sí mismos, escuchan pero no entienden, oyen pero no captan el sentido. De esta forma, dice el fragmento 34: "Incapaces de comprender tras escuchar, se asemejan a los sordos; de ellos da testimonio el proverbio: aunque estén presentes, están ausentes". Y quién más ausente que un enamorado, que solo centra sus pensamientos en su amada, que no escucha ni ve lo que otros dicen, y que no logra concentrarse en otros asuntos diferentes a su propia situación de enamorado que lo embriaga y que se convierte en su única realidad. Un enamorado será entonces como un poeta que no puede hablar de lo universal porque la inspiración ya lo encierra en su propia particularidad.

El hombre que se encierra en sí mismo, lo que hace pues es aislarse de la realidad universal de la physis y prescindir de la significación universal del Logos; con ello lo que hace es llegar a construirse una realidad particular e ilusoria, como la realidad de los sueños. "No se debe obrar ni hablar como cuando estamos dormidos", dice la sentencia 73. Desde aquí se puede rastrear la crítica que hace Heráclito a los poetas como una crítica que se dirige al decir y al hablar del poeta, un decir adornado y particular que hace referencia al mito, un decir que se asemeja a un estado de ensoñación porque se desprende y se distancia del Logos universal y común. Heráclito no está pues contra los poetas mismos ni contra la poesía sino contra la forma de decir de los poetas. Ahora, mientras que Heráclito está siempre apuntando a lo universal, el poeta va siempre hacia la particularidad; el poeta tiene un dominio de lo imaginativo y, en este sentido, encasilla la realidad desde su particular modo de ver el mundo, al igual que lo hace un enamorado. Heráclito ve en el mundo unidad a pesar de la pluralidad y variedad de las cosas, pero los poetas, pese a que buscan abarcar todo, siempre caen en lo particular. Esta construcción propia del poeta intenta hacer creer que esa es la realidad, y los medios que emplea para ello es la palabra, pero no una palabra cualquiera, sino la palabra del poeta, una palabra 
que persuade, que envuelve, y, lo más importante, una palabra que crea mundo. El lenguaje hace parte de la invención del poeta, es un lenguaje que nombra, pero que se desprende y se distancia del logos común. Este lenguaje pertenece a la ensoñación, hace parte de ese estado de aislamiento que es el sueño, así como en sueños se les va la vida a los enamorados, que encantados permanecen y que con extraños lenguajes se encantan y se sumergen en un sueño del que ya no quieren despertar jamás.

Heráclito, por el contrario, según la lectura de Werner Jaeger, quiere despertar a los hombres de sus sueños; esto implica un cambio en la concepción de mundo, este cambio supone, haciendo alusión al fuego heraclíteo, una transformación; el fuego transmuta, tiene la propiedad de cambiar las cosas, implica un movimiento, o como dice Jean Brun: el fuego es la imagen móvil del logos y del uno, haciendo una comparación con Platón cuando expresa en el Timeo que el tiempo es la imagen móvil de la eternidad. La acción del fuego sobre el mundo es pues una transformación que implica un cambiar la representación que los hombres tienden a hacer del mundo.

Por otra parte, Cappelletti nos muestra que el logos se opone al eros, cuyo plural épea designaba ya en tiempos de Heráclito la poesía épica y particularmente los cantos de Homero. Los épea son palabras surgidas de la sensibilidad y de la fantasía y quedan así dentro del dominio de lo particular y de lo arbitrario. Dice Cappelletti: "La opinión es particular, como lo es el ensueño que cada uno tiene cuando se aísla del mundo, cuando se separa de hombres y cosas, cuando cierra los ojos a lo circundante." 35 El arte épico es pues, para Heráclito, dominio de la fantasía y de la sensibilidad. El Logos, en cambio, es la "palabra" que expresa la realidad de la physis. Y como Homero es ajeno al Logos, es entonces incapaz de conocer la physis y es susceptible de ser engañado por los acertijos de unos niños. Por esta razón también se dice que los enamorados son como niños, niños que juegan al amor y que viven siempre en un mundo particular de fantasías.

La segunda sentencia de Heráclito dice: "Por tanto es necesario seguir lo común; pero, aunque el Logos es común, la mayoría vive como si tuviera una inteligencia particular". Sin embargo, en cuanto toda razón individual (o personal) se funda en el Logos universal y participa de él, es "común". Por eso dice Heráclito: "Común a todos es el entender" B113.

Lo común y lo particular se relacionan entonces con las figuras del estar despierto y del estar dormido. Así, mientras que el hombre despierto solo escucha el Logos universal, el dormido, el necio, el enamorado, el loco, solo escucha cualquier Logos y se asombra ante cualquier palabra. "Un hombre estúpido suele excitarse con cualquier palabra" dice el fragmento 87 . Y no es extraño para nadie que los

35. Capelleti, Angel J. La filosofía de Heráclito de Éfeso. Venezuela. Monte Ávila. 1969. pág. 78. 
enamorados en muchos sus actos obran y hablan como estúpidos. Para Heráclito el mythos sería entonces un decir que no es el logos, un decir de los que están dormidos. Dice a su vez el fragmento 89: "Para los despiertos existe un mundo único y común, pero cada uno de los dormidos se aparta hacia el suyo particular" B 89. Aquellos que se desprenden y se distancian del Logos son entonces los que viven en un mundo "particular".

Pero no solo los poetas épicos son incapaces de abrirse al Logos universal, los eruditos puros tampoco tienen acceso a él según apunta Capelletti, pues la simple acumulación de datos, la mera erudición, la pluriciencia, no basta para captar el Logos y para tener entendimiento. "La erudición no enseña a tener entendimiento, pues en tal caso habría enseñado a Hesíodo y a Pitágoras y aun a Jenófanes y Hecateo", dice el fragmento 40. Sin embargo, anota Cappelletti, si se integra la pluriciencia en la unidad del Logos, dichos datos aparecen no solo como útiles y legítimos sino también como necesarios.

La palabra de Heráclito se presenta entonces, siguiendo a Werner Jaeger, como la palabra de un profeta que quiere despertar a los hombres de sus sueños para comunicarles la conciencia de una verdad que no es puramente teórica, sino que debe influir en la conducta, y debe renovar la vida, uniendo a los hombres en un mundo común por la comprensión del logos. Pero a los oídos de los enamorados difícilmente podrán llegar estas palabras del Heráclito como profeta, ellos no desean pertenecer a un mundo común, les basta con su mundo particular.

En relación con esto, podríamos decir que el filósofo que se aparta de la comunidad, que se aísla en su mundo particular, estaría en una situación muy cercana a la situación del enamorado, al no poder escuchar la voz del logos, sino tan solo su propia razón particular. Tal vez por eso nos diga el mismo Heráclito, quien se retiró a las montañas para estar lejos de los hombres, que no lo escuchemos a él sino al propio logos. ¿Qué desamor llegaría a sufrir nuestro filósofo? Tal vez Heráclito estaba enamorado, tal vez por eso no entendemos todavía sus máximas, quizás por eso ellas nos resultan tan oscuras, ininteligibles y a veces contradictorias. Si se trata de escuchar al logos no se puede estar aparte de lo común, pero él siempre quiso estar aparte de lo común, no compartía la política de su ciudad Éfeso y prefería jugar con los niños a participar como ciudadano en la política. Y sin embargo, el segundo fragmento expresa: "Por eso conviene seguir lo que es general a todos, es decir, lo común; pues lo que es general a todos es lo común. Pero aún así siendo este logos general a todos, los más viven como si tuvieran una inteligencia particular".

Siguiendo la indicación de su segundo fragmento, Heráclito, al deshacerse de las representaciones particulares, tiene ya un concepto nuevo del logos que los poetas no conocían todavía. El decir del logos es un decir sin adornos, es un decir que 
pertenece a lo común, pertenece a un estar despiertos, a un estar atentos, es un volverse uno con los otros. Este decir, también es un hacer, es un poieĩn, un poieĩn que está ligado al logos, un hacer en relación con el hacer despierto, como parte integrante de la concepción de mundo. El hombre hace parte del logos, y el poieĩn es propio del hombre, es propio tanto de hombres como de dioses, pero ninguno de ellos ha creado el cosmos. "Este mundo, el mismo para todos, no lo hizo ninguno de los dioses ni de los hombres, sino que ha sido eternamente y es y será un fuego eternamente viviente, que se enciende según medidas y se apaga según medidas".

Terminemos esbozando el cambio de significado de la palabra poiesis en el transcurso de su evolución, que es estudiado en detalle por Emilio Lledó en su texto "El concepto "poiesis" en la filosofía griega. Heráclito-Sofistas-Platón", allí nos dice que la significación general del verbo poieo es la de "hacer", una actividad que primeramente se concretó en algo hecho por las manos, pero que envolvía también un traer a la existencia, un crear, una actividad artística. Pero aunque el significado primitivo de poieĩn comprendía un "hacer" y un efecto material y manual, lo decisivo de ese hacer es que estaba determinado por unas normas, no todavía las technai, sino sencillamente una estructuración, mas o menos racional, de una actividad determinada. Poieĩn en Heráclito aparece con varias significaciones como principio, comienzo, convertir, orden, hacer conforme a una regla, etc, pero lo que aquí nos interesa es la significación de Poiousin, que en Heráclito es un obrar del hombre en cuanto despierto; esta significación, nos dice Emilio Lledó, queda sin embargo diluida. Poieo no se concreta en un objeto, sino que apunta al hacer del hombre en general, a todo lo que en estado de vigilia le acontece, a todo lo que es su vivir despierto.

Poieĩn, en cierto sentido, está determinado por los dos estados del hombre: el estar despiertos y el estar dormidos. El estar dormido corresponde al hacer o al poieĩn de los poetas y de los enamorados. Dice Lledó: "El hombre que vive en el olvido de este logos no está en la realidad sino con el sueño". "En el sueño creemos que hacemos o hablamos, pero nuestro poieĩn o legein no tiene trascendencia ni alcanza realidad, es una pura apariencia de hacer". Por su parte, el estar despierto es un estar atento que implica tener, de alguna manera, un dominio de lo que se hace, un dominio de ese hacer, pues el logos, nos dice Lledó, no es una fuerza estática sino un continuo e incesante hacer. Siguiendo lo anterior, el hacer como poiein que se usaba para nombrar los poetas carece de logos como lo muestra Lledó: la poesía carece de logos y carecen de logos los que escuchan la voz de los poetas.

Ahora, si juntamos el logos, al que está llamado el filósofo, con la poesía enamorada que carece y se aparta de ese logos común, nos encontramos con una nueva concepción de la poiesis; tal vez con esa nueva poiesis que Platón como poeta intenta proponer sigilosamente, que es la poesía del filósofo. Con ello lo que se propone 
es una reconceptualización del sentido de poiesis. Varias cuestiones nos asaltan en el camino al pensar que esta reconceptualización de la poiesis podría brindarnos nuevas respuestas a la poesía enamorada. Esta idea, que bien podría ser objeto de un estudio más amplio, sugeriría que el filósofo, al acercarse a la poesía, también podría llegar a ser poseído por Eros, y en general por los dioses. El filósofo, el que filosofa a lo largo de toda su vida, el apasionado por la sabiduría y por el logos, ya lo podríamos pensar como un ser que puede llegar a enamorarse. Es el contacto con la poesía lo que vuelve al filósofo más susceptible de ser arrojado al antojo de la manía y de la locura del amor. La imagen del filósofo se convierte, con la poesía, en la imagen de un ser menos etéreo; en un ser de carne y hueso; un ser que puede ser visto desde la concepción común del enamorado, que parecía no estar presente en el filósofo, pero que, desde esta óptica, podría ser insinuada.

Ahora, ¿quién más que el filósofo podría ser la figura perfecta del enamorado? Es él quien constantemente se pregunta por la vida, por el amor, por la locura. Es él quien persigue al resbaladizo logos con la misma pasión que persigue al amor, y que pese a sus continuos intentos fallidos por alcanzarlos, no renuncia a sus búsquedas. Es él quien se preocupa por descubrir la naturaleza de sus sentimientos, quien navega por sus confusos pensamientos intentando darles un poco de claridad. Es el filósofo quien muchas veces pasa por loco, por maniático, por despistado, delirante y distraído. Por ello, tal vez sea la figura del filósofo la que mejor se acopla con la figura del enamorado. Lo que se imita entonces en la poesía enamorada sería justamente la locura. El papel que aquí juega la mimesis es el mismo papel que juega la 'manía'. El enamorado deja de ser un enamorado cuando la 'manía' como mimesis deja de poseerlo, puesto que lo que se representa en la poesía enamorada es justamente la locura. 


\section{Bibliografía:}

Barnes, Jonathan. Los presocráticos. Ed. Cátedra. 1992.

Brun, Jean. Heráclito, o el filósofo del eterno retorno. Ed. Edaf. Madrid, 1976.

Capelleti, Angel J. La Filosofía de Heráclito de Éfeso. Venezuela, Monte Ávila, 1969. Fink, Eugen \& Heidegger, Martin. Heráclito. Barcelona: Ariel, 1986.

Gigon, Olof, Los orígenes de la filosofía griega, De Hesíodo a Parménides. Ed. Gredos, 1980.

Guthrie, W. K. C. Historia de la filosofía griega.

Hadot, Pierre. ¿Qué es la filosofía antigua? México. Fondo de Cultura Económica. 1998.

Heidegger, Martin. De camino al habla. Ediciones del Serbal. Barcelona, 1987.

Jaeger, Werner. La teología de los primeros filósofos griegos. Fondo de Cultura Económica, Madrid, 4a reimpresión, 1993.

Kirk, Raven \& Schoefield. Los Filósofos Presocráticos. Madrid: Gredos, 1994.

Lledó Î́nigo, Emilio. El concepto "Poíesis" en la filosofía griega. Heráclito-SofistasPlatón. Consejo Superior de Investigaciones Científicas. Instituto "Luis Vives" de Filosofía, Madrid, 1961.

Mondolfo, Rodolfo. Heráclito, textos y problemas de su interpretación. Siglo veintiuno editores. Colombia, 1983

Nietzsche, Friedrich. Los Filósofos Preplatónicos. Madrid: Trotta, 2003.

Platón. Obras completas. Madrid: Gredos, 1993-1999 


\title{
III.
}

\section{La mimesis poética y su relación con el saber ${ }^{36}$.}

\author{
Por: Luis Guillermo Quijano Restrepo
}

El profesor Quijano es actualmente Profesor y director del Programa de Licenciatura en filosofía de la Universidad Tecnológica de Pereira desde 2007. Realizó su pregrado (1999) y maestría (2005) en filosofía en la Universidad de Antioquia. Así mismo es profesor de música (curso de estructuras e historia de la música) en la escuela de música de la Universidad Tecnológica de Pereira. Es el investigador principal del Grupo de investigación en Estética y Expresión desde 2008.

Resumen: Este texto se dedicará en especial a los libros II, III, y X de la República, donde se considerará el asunto de la mimesis en cuanto a la forma y el contenido. En la primera parte, se tratará sobre el libro II, donde Sócrates le da a Adimanto (interlocutor de Sócrates en la República) las reglas que debe seguir un poeta para hablar adecuadamente de los dioses y héroes que canta. La segunda parte, se dedicará al libro III, en el cual se distingue la "verdadera mentira" de la "mentira innoble" que dará lugar a las imágenes con las que el poeta se vale para hacer sus imitaciones. Así mismo, define las formas de relato entre las que se destaca la de la mimesis. Esto con el fin de mostrar que los relatos, aunque sean mentiras, hechos con el contenido y las formas adecuadas, pueden llegar a ser benéficos y nobles para los hombres y servirles como remedio (phármako) para su alma. La tercera parte se centrará en el libro $\mathrm{X}$, donde se elabora la crítica a la mimesis, su relación con las realidades o Ideas y de los peligros a los que llevarían al alma (y por consiguiente al propio Estado) por dejarse seducir de los hechizos de los poetas y caer así en un estado de akrasía al no tener el remedio de la razón como antídoto.

En este artículo nos orientaremos a la dilucidación de los libros II, III, y X de la República, en relación con el problema de la producción poética bajo la óptica de la mimesis y sus implicaciones en el campo del saber, de las leyes, y de la opinión. ¿Quiere decir esto que la explicación de la poesía como inspiración abordada en el Ion, en el Cármides y en el Fedro es abandonada ya en la República? ¿Por qué ni se

\footnotetext{
36. Este artículo hace parte del texto de trabajo de grado (capítulo II) para maestría titulado "Platón el poeta legislador", y que fuera publicado por E.A.E, en 2012.
} 
menciona en este último? ¿Es tomada la mimesis como una superación de la teoría de la inspiración? Ni se abandona, ni se supera, sino que explica dos cosas distintas, o, más bien, el problema de la mimesis se aplica de manera distinta. Si bien en el Ion no se hace explícita la referencia a las artes miméticas, estaban allí implícitas en la consideración que hiciera de ellas Sócrates en el fragmento correspondiente a la segunda serie de técnicas como la pintura, la escultura, la música, y la rapsodia ${ }^{37}$. Así mismo en la República, si bien no se menciona el problema de la inspiración, sí se tiene en cuenta cuando Sócrates habla del tipo de poesía que se debe admitir en el Estado: himnos para los dioses y alabanzas a los hombres buenos, pero "si en cambio recibes a la Musa dulzona, sea en versos líricos o épicos, el placer y el dolor reinarán en tu Estado en lugar de la ley y de la razón que la comunidad juzgue siempre la mejor"38. Se trata aquí de que el poeta se deje guiar por la Musa conveniente a la ciudad. Así, habrá un tipo de mimesis que es la apropiada para el Estado y que dirige la Musa óptima, y otro tipo de mimesis que no es conveniente para el Estado y que orienta la Musa dulzona. Con lo anterior constatamos que Platón no abandonó la teoría de la inspiración. Tampoco la supera, puesto que la mimesis, en el texto que se abordará, no responde más que a la pregunta del qué (contenido) y el cómo (forma) de la poesía, en tanto que parten del hombre. La crítica, pues, que Platón hace en la República, no está dirigida a la poesía inspirada por la divinidad, sino aquella que, al alejarse de la verdad de los dioses y los hombres buenos, no está inspirada por los mismos.

Entendemos por mimesis la imitación (o representación) de lo aparente, esto es, de aquello que aparece tal como aparece, y no como lo que es ${ }^{39}$. La mimesis, o más bien el mimetés (trátese de pintor, poeta, trágico, etc), se ubica en el tercer grado, "contando a partir del rey", es decir, está después de los artesanos (demiourgói) y este a su vez, después del "productor de naturalezas" (phytourgós) quien produce precisamente el mundo de las Ideas. El arte de la imitación produciría también todas las cosas pero de manera parcial y ello a través de la imagen (eídolon): “...el arte mimético está sin duda lejos de la verdad, según parece; y por eso produce todas las cosas pero toca a penas un poco de cada una, y este poco es una imagen" ${ }^{40}$

Como podemos notar la mimesis abarca, como producción, todas aquellas cosas, personas, estados o actos que puedan ser representados, esto es, que puedan, por decirlo de alguna manera, ser traducidas a imágenes (eídola). Así, pues, el pintor

37. Platón. Ion. Madrid. Gredos. 1999. 533a-c.

38. Platón. República. Madrid. Gredos 607a.

39. Ibid. 598b.

40. Ídem. 
puede representar en imágenes la figura de un carpintero, por ejemplo; el poeta puede representar en imágenes verbales una batalla, así como también describirnos un dios; el trágico puede representar con su imagen un carácter dramático, por ejemplo, Edipo, o también incluso a un dios. Esto último, el poder representar lo divino, les ha valido a los poetas su condición de taumaturgos y hechiceros, es decir, de mentirosos y engañadores. Esto, sin embargo, no es exclusivo de los poetas, es parte de la naturaleza misma de la mimesis, pues el representar la apariencia (phantasma) ya de por sí es un engaño: "No obstante, si es buen pintor, al retratar a un carpintero y mostrar su cuadro de lejos, engañará a niños y a hombres insensatos, haciéndoles creer que es un carpintero de verdad". ${ }^{4}$

Si bien el ejemplo del pintor es un tanto exagerado en la cotidianidad, no lo es así en el teatro de la comedia, por ejemplo, donde el espectador (sensato) aunque sabe que el mimo lleva una máscara que representa a un personaje público (por ejemplo Sócrates mismo en las Nubes de Aristófanes), llegará un momento en el cual se pierda esa conciencia (si además de esa máscara, que representa los caracteres del personaje en cuestión, esté acompañado de la correcta representación de sus gestos y locuciones propias) y se crea por momentos que efectivamente ese actor es Sócrates en persona, pues de lo contrario la comedia no tendría ningún efecto en el espectador (theatés). Y ya que tocamos el asunto de los poetas, digamos que sería posible, no obstante, hacer una distinción no solo en cuanto al medio por el cual el poeta expresa su mimesis, que es una diferencia obvia con el pintor, en tanto en aquel su medio es la palabra, mientras que en este otro necesita de una superficie y un grafito para dibujar. La distinción en cuestión es la que tiene que ver con el grado de engaño del que es capaz el mimetés y del perjuicio que entraña. En el caso del pintor, el perjuicio para el engañado es mínimo, pues se trataría tan solo de una especie de trompe- l'oeil (no es lo único, por supuesto, pues recuérdese que se necesita además un toque de insensatez o puerilidad también). En cambio no sería lo mismo para quien escucha un poema o asiste a una representación teatral, pues el uso de la palabra ya implica un terreno común al saber en general, y por ende a la virtud misma. No en vano Sócrates ataca con insistencia a los poetas en cuanto se presumen educadores de la Hélade, pues bien sabe que lo han sido desde tiempos inmemoriales y que aún en vida de él lo seguían siendo. Y es que la acusación no era en vano, pues ostentaban para sí un saber que abarcaba todo lo divino y lo humano al incluir en sus relatos o piezas teatrales asuntos que en estricto sentido no le corresponden sino a aquellos que detentan tal o cual saber. Por ello no pueden ser más que tenidos como taumaturgos y hechiceros:

41. Ídem. 
...si alguien viene a avisarnos que ha hallado a un hombre entendido en todos los oficios y en todas aquellas cosas que cada uno conoce, y que no hay nada en que él no sea entendido con mayor precisión que cualquier otro, es necesario replicar a tal persona que es muy cándida y que, al parecer, ha dado con algún hechicero o imitador que la ha engañado; de modo que, si le ha parecido que era alguien omnisapiente, ha sido por no ser capaz de discernir la ciencia de la ignorancia y de la imitación. ${ }^{42}$

El calificativo de hechicero (góes) dado por Sócrates a los poetas que dicen saber de todo (pánsophos), resuena inmediatamente con la figura del sofista, con quien el poeta se iguala en argucias. No en vano en el Sofista 268c, a este se le define como un "imitador del sabio". Ambos utilizan la palabra y hacen encantamientos con ellas, hablan de todo, pero además, educan a la polis en todas las ramas del saber, desde las artesanales, pasando por el estado, sus leyes y remontándose finalmente a los dioses incluso. Más adelante veremos que ambos, el sofista y el poeta tienen, desde la perspectiva platónica, claro, muchos más rasgos afines. Ambos, pues, tienen en común la mentira, y aparte de que ésta pueda ser útil (para los hombres) e inútil (para losdioses), produce ante todo un daño que no es sino curable a partir del mejor antídoto (phármakon), el saber, o el discernir mejor entre las realidades y las apariencias. Para efectos de comprender mejor la mentira en los poetas y sus implicaciones con el Estado, pasaremos a considerar lo dicho en el libro II de la República.

\section{Libro II: La mentira innoble}

Detengámonos en aquello que Sócrates define como una "innoble mentira" (me kalós pseudẽtai) el "caso en que se representan mal con el lenguaje los dioses y los héroes" ${ }^{43}$. Esta consideración pertenece al pasaje que comprende desde el $377 \mathrm{~d}$, donde aparecen aquellos mitos bajo el calificativo de "mentiras innobles", hasta el 383 c, donde se censura a los poetas y se les castiga con el silencio. Pero antes de abordar tal asunto, se hace necesario recordar el momento en el cual "toda clase de cautivadores e imitadores" 44 hacen su aparición en la República ideada por Sócrates como respuesta a la inquietud de Glaucón y los demás, sobre la indagación de lo que es la justicia y la injusticia. Sócrates recurre a la imagen de las letras más grandes, para después observar si las más pequeñas son las mismas que aquellas, es decir, indagar si a través de la figura del Estado (letra mayor), podemos reconocer

\section{Ibíd. 598c-d.}

43. Ibíd. 377d.

44. Ibíd. 373b. 
luego al individuo (letra menor) y su relación con la justicia ${ }^{45}$. Así, pues, Sócrates hace nacer el Estado "cuando cada uno de nosotros no se autoabastece, sino que necesita de muchas cosas" 46 . No nos detendremos en cada una de las divisiones y clasificaciones que propone Sócrates. No más diremos que, luego de que los oficios están repartidos, y luego de que surge el intercambio de bienes, o sea el comercio, se establecen unos lazos sociales determinados por tales relaciones, como es el caso de los mercaderes y los asalariados, esto es, una sociedad en la cual se cumple que cada quien se dedique a lo suyo, y que consiga lo que necesita de los otros a través de un "sano" intercambio. Esta es, en fin, la sociedad perfecta, o mejor, como lo dice el propio Sócrates, "el Estado sano" (hygiés pólis). Pues bien, el Estado injusto aparece en la medida en que entra el concepto de "Estado lujoso", que corresponde con el Estado insano, o afiebrado. A continuación aparecen entonces los imitadores, como fruto del lujo de la sociedad, pero también como causa de su enfermedad. Lo irónico es que aparecen como con cierto carácter de necesariedad (¿para el Estado mismo?), en la medida en que este va creciendo cada vez más y se va apartando de las necesidades (anagkaĩa) propias del Estado. No es (para el hombre) suficiente con que un Estado satisfaga las necesidades básicas, es necesario, además, que crezca a partir de otras exigencias:

-Entonces, ¿no será necesario agrandar el Estado? Porque aquel Estado sano no es ya suficiente, sino que debe aumentarse su tamaño y llenarlo con multitud de gente que no tiene ya en vista las necesidades en el Estado. Por ejemplo, toda clase de cazadores y de imitadores, tanto los que se ocupan de figuras y colores cuanto los ocupados en la música; los poetas y sus auxiliares, tales como rapsodos, los actores, los bailarines, los empresarios; y los artesanos fabricantes de toda variedad de artículos, entre otros también de los que conciernen al adorno femenino. ${ }^{47}$

Es claro que los imitadores no se toman como parte de un Estado sano. Y como este deviene insano a causa de estos lujos, es cuando aparece la necesidad de la educación, que tiene como fin, formar a los "guardianes" que cuidarán del Estado para que no se vea afectado por la enfermedad y termine muriéndose. Así, pues, los guardianes deben ser en general fuertes, agudos en la percepción y rápidos en la persecución, y que anide en ellos la valentía para la defensa de la ciudad en la guerra. Pero de otra parte su alma debe, aparte de ser fogosa, ser mansa, característica propia

45. Ibid. 368d.

46. Ibíd. 369b.

ores 
de los perros, con los que se compara el carácter del filósofo, pues el perro distingue al amo (a quien ama) del extraño (a quien agrede). Al menos en su comportamiento así lo refleja. Por eso el guardián debe ser, como el perro, amante del conocimiento. Debido a esta naturaleza mansa y amorosa, el guardián debe ser entonces educado. Se comienza entonces con la música antes que con la gimnástica, pues aquella incluye discursos, pero que son, en primer lugar, falsos:

-Pues bien, ¿no comenzaremos por la música antes que por la gimnástica?

-Ciertamente.

¡¡Y en la música incluyes discursos o no?

_Por mi parte sí.

-Ahora bien, hay dos clases de discurso, uno verdadero y otro falso.

¡¡Así es!

- ¿Y no hay que educarlos por medio de ambas clases, y en primer lugar por medio de los discursos falsos?

-No entiendo qué quieres decir.

-¿No entiendes_pregunté_que primeramente contamos a los niños mitos, y que éstos son en general falsos, aunque también haya en ellos algo de verdad? Y antes que de la gimnasia haremos uso de los mitos. ${ }^{48}$

Notamos el aspecto de necesidad de la mentira, en tanto es natural al mito, pero en el cual, no obstante, no se excluye del todo su parte de verdad, y que, en última instancia, va a ser útil para la formación de los guardianes. De lo que se trata ahora es de regular el contenido de tales discursos y mínimamente encaminarlos más a lo que tengan de verdad que de mentira. Se empieza a censurar, pues, ante todo los "mitos mayores", es decir, los que vienen de Homero y Hesíodo y donde se encuentran las "mentiras innobles". Cabría hacer aquí una definición de lo que Sócrates concibe como mithós y que parece estar insinuada en estas anteriores líneas

48. Ibíd. 376e-377a. 
como un discurso (lógos) falso (pseudós).

Ahora bien, concentrémonos en la razón del rechazo de estos discursos por parte de Sócrates. En primera instancia, Sócrates censura aquellos mitos en los que ponen a los dioses con rasgos pasionales característicos de los hombres, entre los que se cuentan por ejemplo, la venganza de Crono sobre Urano por su comportamiento (como padre) ante los Titanes, tal como Hesíodo lo relata en su Teogonía; o que entre los dioses existan rencillas, y guerras entre unos y otros, como lo relata Homero en la Iliada; o bien el castigo que infligió Zeus a Hefesto por defender su madre, etc. Estos discursos serían inapropiados para niños que aún no tienen discernimiento sobre lo que es alegórico y sobre lo que no lo es. Por esta razón deberán ser los mitos los más bellos y los más encaminados a la excelencia ${ }^{49}$. Ello exige, pues, que, como fundadores de un Estado, y no como poetas, se pongan en la tarea de dar las pautas que determinen la manera en que los poetas deben hacer sus creaciones. La primera de ella versa así:

...debe representarse siempre al dios como es realmente, ya sea en versos épicos o líricos o en la tragedia.

-Eso es necesario

-Ahora bien, ¿no es el dios realmente bueno por sí, y de ese modo debe hablarse de él? ${ }^{50}$

He aquí, la primera exigencia dada al poeta: representar la naturaleza del dios, es decir, tal como es realmente. Y la realidad del dios es que es bueno por sí. De esta primera se sigue:

-"En ese caso, lo bueno no es causa de todas las cosas; es causa de las cosas que están bien, no de las malas".

La regla está orientada a criticar la concepción homérica en la cual la divinidad es causa tanto de los bienes como de los males que le acontecen a la humanidad, esto implica no solo que los dioses no deban ser representados distribuyendo mezclados los bienes y los males, ni dando males con mezcla de bienes, sino que además ellos deben ser los encargados de velar porque no se rompan los juramentos y pactos, además de ser los que dispensan los castigos justos, de acuerdo a la culpa del que los cometa, esto es, los juramentos y pactos no se pueden romper o incumplir a nombre de ningún dios, y en ese sentido, tampoco podrán sentirse infortunados los que expían sus delitos a causa de ellos.

49. Ibíd. 378e.

50. Ibíd. 379a. 
La segunda de las reglas está orientada a mostrar que el dios es inmutable, su naturaleza es simple, que no muda de aspecto, y que por ello mismo no es un hechicero, ello implica que no está en su naturaleza engañar al hombre con cambios en su naturaleza.

...”ंNo crees, por el contrario, que el dios es simple y es, de todos los seres, quien menos puede abandonar su propio aspecto?". ${ }^{51}$

Ello implica, además, que el dios, fuera de no modificarse a sí mismo, no pueda ser modificado por otro diferente a él, pues aquella alma que no permite ser modificada o perturbada, es más sabia y vigorosa, cuanto más la que pertenece a la misma divinidad

En el caso de que sea por obra de otro hallaremos que las cosas mejores son las que menos pueden ser alteradas o modificadas...

¿Y no es el alma más vigorosa y más sabia la que menos puede ser perturbada o modificada por cualquier factor externo? ${ }^{52}$

En este sentido, no podrá ser posible concebir a un dios transformándose y mucho menos en algo peor o algo más feo, tal como las transformaciones de Proteo en león, dragón, pantera, jabalí, agua y árbol, para escapar infructuosamente de Menelao; o bien las transformaciones de Tetis cantadas también por Homero, para evitar su desposorio con Peleo, etc, pues todas las cualidades del dios apuntan solo a la excelencia, es decir, todo en el dios es perfecto y bello y "por ser el más bello y mejor posible, ha de permanecer siempre simplemente, en su propia forma" ${ }^{53}$.

Finalmente, y aquí es donde aparecerá el concepto de mimesis, los dioses, si bien no cambian su aspecto desde sí mismos ni desde otros, tampoco está en sus manos el mostrársenos de múltiples aspectos por medio de engaños o brujerías, pues el dios no está dispuesto a mentir por ningún medio ${ }^{54}$. Sin embargo hay que hacer una distinción presente en este pasaje: la mentira como "verdadera mentira" (alethós pseudós), y como "mentira innoble" (me kalós pseudêtai). La primera no es más que "la ignorancia en el alma de quien está engañado" ${ }^{5}$, y que además es odiosa tanto para dioses como para hombres, pues nadie quiere ser y estar engañado en el alma con respecto a la realidad. Esta sería algo así como una mentira absolutamente

51. Ibíd. 380d.

52. Ídem.

53. Ibíd. 381c.

54. Ibíd. 382a.

55. Ibíd. 382b. 
pura. La segunda es la mentira "expresada en palabras", es decir, aquella que se hace posteriormente (hýsteros) una imagen de algo que afecta el alma. Esta clase de mentira no es una "mentira absolutamente pura", y tiene el nombre de imitación (mímema), esto es, algo que es representado con posterioridad a la afección misma. Nótese que Platón emplea el sufijo _ma, que se emplea para designar sustantivos que hacen referencia a una concreción, a un producto de la mimesis, esto es, un resultante pasivo perteneciente a la actividad propia de aquella ${ }^{56}$.

...Porque la mentira expresada en palabras es sólo una imitación de la que afecta al alma; es una imagen que surge posteriormente, pero no una mentira absolutamente pura" ${ }^{57}$

Este tipo de mentira que se expresa en palabras, si bien engaña, no es un engaño tan perjudicial como el de la "verdadera mentira" que afecta al alma por el engaño acerca de las cosas reales. La imitación, como mentira, afecta al alma desde la imagen que se representa, pero si se utiliza de manera adecuada y con fines nobles, dejaría de ser perjudicial. Esto permite vislumbrar un cierto aspecto positivo de la misma, pues al no ser una mentira absoluta, su permisividad radicaría en su condición de útil (chresímos), adviértase también que la raíz de esta palabra, chré tiene el sentido igualmente de necesidad. Es necesario, pues, que la imitación se presente en el alma como útil, en la medida que la imagen que nos hacemos después de algo o alguien que ha afectado nuestra alma, se dé como remedio, esto es, como phármakon.

-En cuanto a la mentira expresada en palabras, ¿cuándo y a quién es útil como para no merecer ser odiosa? ¿No se volverá útil, tal como un remedio que se emplea preventivamente, frente a los enemigos, y también cuando los llamados amigos intentan hacer algo malo, por un arranque de locura o de algún tipo de insensatez? Y también en la composición de los mitos de que acabamos de hablar ¿no tornamos a la mentira útil cuando, por desconocer hasta qué punto son ciertos los hechos de la antigüedad, la asimilamos lo más posible a la verdad ${ }^{58}$

Se da como útil solo para el hombre, limitado en su capacidad de conocer y en su condición mudable. Mas no es posible concebirlo en los dioses, para quienes la mentira es completamente ajena a su naturaleza perfecta. Si bien la imitación

\footnotetext{
56. Confróntese el estudio del catedrático Emilio Lledó Iñigo, El concepto “poiesis” en la filosofía griega. Madrid. Bermejo. 1961. pág. 37.

57. Ídem.

58. Ibíd. 382c-d.
} 
misma pueda servirle al hombre como útil en ciertos aspectos, ello no implica que pueda utilizarla amañadamente para hacerse una representación de los dioses. De aquí viene, la censura que Sócrates le hace a los trágicos, en la persona de Esquilo, de quien se ha valido para mostrar los ejemplos a no seguir en la composición poética, en tanto este pone en boca de Tetis las argucias, mentiras y crimen que el propio Apolo cometió contra su hijo (de ella) Aquiles [Esquilo, fr.350,1-9].

Retomemos de nuevo aquello que habíamos mencionado con anterioridad con respecto a la comparación entre la imitación propia del pintor, y la del poeta o trágico, con el fin de establecer la conexión entre la "verdadera mentira" y la "mentira innoble" y el error del poeta en representar a los dioses como lo ha venido haciendo. Vemos que Sócrates se ha valido de tal comparación, para hacernos comprender a partir del eíkon, propio de la pintura y de su poder retratista de las cosas y personas, para trasladarlo a una manera igualmente icónica de representación pero más abstracta y más poderosa aun: la palabra. Y tal como hemos visto, no se le reprocha a la imitación, en tanto mentira innoble (en este caso a través de los mitos), el valerse de imágenes, tampoco el que quiera representar lo irrepresentable, sino que se sirva no de la realidad, sino de una simple apariencia (phántasmata), que no tiene nada de verdad, que deriva su imagen de una mentira absolutamente pura, esto es, de una "verdadera mentira", que tanto hombres como mortales detestan. Así que esta imitación, la que censura Sócrates, no es una mera imagen que aparece posteriormente a la afección que recibe el alma de algo real. Esta imitación es la imagen de una ignorancia, la imitación de un engaño: "la verdadera mentira". Pero esto no termina aquí, el problema que reúne a todos los demás es que los poetas se crean portadores de un saber que solo existe en su creación poética bajo una forma apariencial, que no tiene ningún referente real, un saber en fin, que es pura falsedad, pero que se quiere imponer como el verdadero saber. Homero, Hesíodo, Esquilo, no hacen más que hablar de todo lo humano y divino sin ser ellos mismos portadores del saber que presumen. Ya entendemos por qué no concibe Sócrates el oficio de poeta o trágico en los términos que se nos ha presentado. Todo radica en la falacia que le hacen creer al espectador, y en general a toda la polis, que ellos, que hablan de todo, son unos sabios de todo lo que dicen, pues son pánsophos. Falacia que va en contra del principio por el cual surge un Estado (hablamos de un Estado sano, por supuesto), y es aquel en el que nadie es autosuficiente, y en el que todos sus ciudadanos deben dedicarse a un único oficio y dar cuenta solo de él, pues de lo contrario, no tendría sentido establecer relaciones entre sí. Es decir, es necesario en un Estado que todos sus miembros tengan vínculos de dependencia con los demás, para que este mismo no se desgrane, ni se divida y ocasione por ello un Estado anómico. El poeta, tanto como el sofista, serían los responsables del desorden político. Por ello si no se acomodan a los principios atrás establecidos, los poetas 
serán motivo de cólera para los legisladores y serán por ello sancionados:

Cuando un poeta diga cosas de tal índole acerca de los dioses, nos encolerizaremos con él y no le facilitaremos un coro. Tampoco permitiremos que su obra sea utilizada para la educación de los jóvenes; al menos si nos proponemos que los guardianes respeten a los dioses y se aproximen a lo divino, en la medida que eso es posible para un hombre. ${ }^{59}$

\section{Libro III: La mimesis}

Pasemos ahora a la consideración del libro III, de la República, en donde ya concretamente se habla de mimesis en cuanto a su forma, diferenciándola de la narrativa simple. En este contexto va a ser definida la mimesis en cuanto a la poesía en general, pero haciendo énfasis en la tragedia. Dejaremos de lado todo el asunto de la formación de los guerreros a partir del mito ${ }^{60}$, en lo concerniente a que este no fomente a través del ejemplo de los héroes o dioses, el temor a la muerte, sino la valentía; que destierre los lamentos en los hombres, y anime a la templanza, a la moderación de los apetitos, a la perseverancia; que no se fomente tampoco por los poetas el apego a las riquezas, a las matanzas, etc, etc. De estos pasajes solo tomaremos uno, el cual está en conexión con el problema de la mentira, expuesto anteriormente. Sócrates le recuerda a Adimanto que ya se había hablado de una clase de mentira que era útil al hombre en calidad de phármakon. Pues bien, Sócrates advierte que este, en calidad de remedio, no puede ser administrado más que por el que sabe, es decir, por el médico, y no por gente profana. Aquí se entiende que este médico no es específicamente el médico que cura el cuerpo. El médico en este caso está representando (de nuevo el eídolon platónico) en el guardián que ya pasó su proceso de educación. A estos y solo a estos es que les será permitido hacer uso de este pharmakon, es más, no importa que se revista de mentira, con tal de que sea útil y benéfico para el Estado:

"Si es adecuado que algunos hombres mientan, éstos serán los que gobiernan el Estado, y que frente a sus enemigos o frente a los ciudadanos mientan para beneficio del Estado; a todos los demás les estará vedado". ${ }^{61}$

En lo que respecta a nuestro interés, nos centraremos en lo dicho entre los pasajes 392 c, donde se va a distinguir los tres tipos de narración, a saber, la narración

59. Ibid. 383c.

60. Ibíd. 386a-392a.

61. Ibíd. 389b. 
simple, la narración imitativa, y la mixta, hasta la expulsión de los poetas trágicos del Estado, hasta el 398b. No nos detendremos tampoco en el carácter de los cantos y de las melodías y todo lo que está orientado al discurso de la música y su fin como "amor a lo bello" 62 , y esto no porque no sea útil a nuestra investigación, sino que no corresponde con el tema que nos concierne ahora. Tampoco nos detendremos en los pasajes que tratan sobre el amor al cuerpo en lo que respecta a la gimnástica ${ }^{63}$. Mas sí en los últimos pasajes en los que se habla de nuevo de los peligros de los hechizos y los olvidos para el pensamiento de los gobernantes ${ }^{64}$, para concluir finalmente con la referencia a la invención de una "mentira noble", relatada por Sócrates a Adimanto acerca de los "hijos-de-la tierra" 65.

Visto nuestro derrotero para el libro III, comencemos a abordar el problema del discurso (lógos) en cuanto a su dicción, esto es, del modo en que debe ser dicho. Se empieza con una consideración temporal, que es el elemento común para todo tipo de narraciones. En efecto, todo relato o composición mítica hecha por poetas acontece en el tiempo, tanto de lo que ha pasado (gegónoton), como de las cosas que pasan (ónton) y de lo que pasará (méllonton). Es una consideración harto interesante, pues resulta que el poeta no solo ha hablado de todo lo existente presente o ausente actual (ta ónta), sino que además ha relatado (légetai) sobre aquello que fue es y que será. Se hace por ello casi necesario traer a la memoria el fragmento de Homero (Iliada, canto I) que ilustra en qué consiste el saber de Calcas como vidente y que reza así:

...De nuevo levantose Calcas el Testórida, el más sabio de los videntes, el que conocía lo que es, lo que será, lo que fue antes, quién también guió hacia acá, ante Troya, los buques de los Danaos, con espíritu profético, de Febo Apolo por él venerado.

Lo traemos a consideración más que por mostrar alguna correspondencia meramente con el tiempo en ambas citas, es por aclarar su diferencia esencial. Pues Platón menciona aquí el tiempo solo desde un punto de vista de un mero relato (diégesis), de un hablar (légein), que no es en ninguna manera sabiduría, pues hablar, por muy poético o adornado que sea, no puede ser igual a un saber. Diferente a este otro saber del vidente, que no solo habla, sino que ve (eído), esto es, el saber es ante todo visión, pero visión de la totalidad, y no solo de los ta ónta en su concepción homérica, sino de las Ideas, es decir, el saber como pura visión eidética. El poeta, si

62. Ibíd. 398c-403c.

63. Ibíd. 403d-410b.

64. Ibíd. 412e.

65. Ibíd. 414d. 
tiene visiones, será en orden a las apariencias, esto es, a la ignorancia que reside en su alma como engaño. Surge de todo esto varias preguntas: ¿qué pasó con la teoría de la inspiración en el Ion? ¿Por qué Platón ni siquiera la menciona en la República? ¿Es la imitación (mimesis) de naturaleza distinta a la inspiración? Pues la inspiración, en tanto endiosamiento, pone al poeta fuera de sí y lo transporta a un lugar propio de la divinidad, en este caso de las Musas. Se desprende de ello que lo que el poeta dice es gracias a que la divinidad le concede el don (theía Moĩra) de libar de sus fuentes y transformarlas en canto. ¿No podríamos pensar que tal inspiración es también una visión? Eso no parece muy claro en el Ion, pues no nos informa que el poeta sea un vidente. En el Fedro tampoco. Sin embargo, el hecho es que en este diálogo la manía adivinatoria que es concedida por el dios hace al poseso vidente, como en el caso de Calcas en el pasaje de la Iliada. ¿No se hace de alguna manera también vidente el poeta ${ }^{66}$ ? ¿Pero podría también ocurrir que, si las tuviera, tales visiones del poeta no siempre están asistidas por la divinidad? Y en tal caso que no las tenga ¿Cómo se le hacen presentes las cosas que el relata en el tiempo? Digamos solo de la narración simple que se presenta como un relato en el cual el poeta habla desde sí mismo como narrador de hechos (prãgmata), como si él mismo hubiera estado presente en ellos, sin utilizar el recurso del diálogo, esto es, sin involucrar a otro u otros en una conversación. En pocas palabras sin que el poeta represente a nadie o semeje a nadie más que a él mismo. Corresponde a los relatos que intercala el poeta entre los discursos de los personajes.

\section{..."habla el poeta mismo sin tratar de cambiar nuestra idea de que es él mismo y no otro quien habla". ${ }^{67}$}

Más adelante dice Sócrates que este será el lenguaje propio de los ditirambos, en los que el poeta se limita a recitar, y de algunos pasajes de los poemas épicos. En tanto el relato imitativo será aquel en el cual el poeta habla como si fuera otro, simulándolo en su dicción propia.

"Y asemejarse uno mismo a otro en habla o aspecto ¿no es imitar a aquel al cual uno se asemeja?"68

En este tipo de narración, el poeta actúa como si "se escondiese" (apokrýptoito) para

68. Ídem. 
dar lugar a otro en su discurso. En los poemas épicos esto se da además a partir de una anticipación (proeĩpe) del personaje que el poeta va a imitar. Finalmente se habla de otra forma en la que se reúne a las dos anteriores, esto es, a la simple que es propia de los ditirambos y a la imitativa propia de la tragedia y la comedia, y que se emplea precisamente en la poesía épica ${ }^{69}$.

Establecidas ya las tres formas de relato, se procede luego a examinar si es conveniente que los poetas utilicen en los relatos solo imitación, o bien en parte sí y en parte no, o si no se les permitirá en absoluto imitar. Platón no descartará la mimesis, pero la pondrá muy por debajo de las otras formas. Este pasaje, más que pretender zanjar la cuestión de admitir o no la tragedia y la comedia ${ }^{70}$, pretende más bien considerar si a los guardianes del Estado les correspondería o no dedicarse a la imitación. Y en este sentido se hace necesario volver a recordar que en un Estado como el que concibe Sócrates, no es posible pensar a estos haciendo más de un oficio, pero además, como es una obligación para todos, los imitadores tendrán que dedicarse a un solo tipo de imitación: o bien la trágica, bien la cómica. Pero la disposición debe ir incluso más allá: no se debe imitar más que un solo carácter, pues imitar todos no es propio de los hombres de bien, ya que el imitar caracteres viles, femeninos (recuérdese que tanto en la tragedia como en la comedia, solo los hombres eran los encargados de hacer todo tipo de representaciones, incluso los femeninos), serviles o de esclavos, o bien de los que enloquecen (mainómenois), induciría en ellos el hábito y la naturaleza misma de tales personas. Por eso se hace necesario solo la caracterización de un solo tipo y el mejor de todos ellos, "para que no suceda que a raíz de la imitación, se compenetren con su realidad"71. Tampoco los oficios propios de los artesanos, como los herreros, o actividades de gente ruda como los remeros o similares, serán objeto de imitación. Mucho menos se imitarán los sonidos pertenecientes a bestias, como por ejemplo, el mugido de los toros, tampoco fenómenos naturales como los truenos o cosas parecidas, pues este tipo de cosas pertenecen a gente demente que ya con anterioridad se les había rechazado. En este estado de cosas pareciera que la imitación como tal no tendría cabida en la República, sin embargo, no es del todo rechazada. Si bien el hombre íntegro evitará y estará menos dispuesto a imitar tales estados viles, se le permitiría en tanto aquel a quien imite "haga algo de valor", mas sin embargo no dejará tampoco de avergonzarse por ello.

..."en parte por carecer de práctica en la imitación de tales personajes, en parte por sentir repulsión hacia el amoldarse

69. Ibíd. 394c.

70.Ibíd. 394d.

71. Ibíd. 395d. 
él mismo y adaptarse a los tipos de baja ralea; desdeñará estas cosas, excepto como pasatiempo"72.

Esto último es de gran importancia en nuestro estudio, pues la imitación en tanto pasatiempo (paidías charín), es tenido por un juego (paidían), en el cual nada puede ser tenido por serio, no obstante ser el tipo de imitación que por ello más agrada a los niños (paisí), tanto como a sus maestros (paidagogóis). Esto lo vuelve a referir Sócrates más adelante en el libro $\mathrm{X}^{73}$, donde el imitador, por ser alguien que no conoce a fondo las cosas que imita, se vuelve su representación una mera farsa.

-"Entonces parece que estamos razonablemente de acuerdo en que el imitador no conoce nada digno de mención en lo tocante a aquello que imita, sino que la imitación es como un juego que no debe ser tomado en serio"...

Parece ser que el sentido de esto último hace a Sócrates de nuevo ser un "ridículo y obscuro maestro", ya que él mismo no lo toma de esta manera, esto es, la imitación como un mero juego de niños (paisí), sino que la ha asumido como un asunto que de ahora en adelante debe ser tomado muy en serio, no en vano se legislará sobre ello. No debemos creer, pues, a pie juntillas todo lo que dice en tono sentencioso y definitivo. Lo que podríamos más bien preguntarnos es si ha existido o existe un estatuto del juego que sí se ha tomado en serio, un juego en el cual el azar y la casualidad, sean los rectores de un milenario uso, cuyo representante sea la propia divinidad. Recordemos solo el rasgo infantil en que a veces se nos presenta, sobre todo en aquel Dioniso que es engañado por los Titanes con unos juguetes que van a ser el objeto de su propia perdición, o tal vez mejor, de su total glorificación, descuartizamiento de miembros, que se revuelven en un movimiento azaroso que recuerda lo caprichoso de los dados. Por ello mismo no es de despreciar enteramente lo que implica el juego, y con él la imitación como tal, antes bien, se le ubica en un lugar inferior a cualquier otra manifestación no tanto por su condición meramente pueril, como ya hemos notado, sino y ante todo, por su condición sub-versiva (cosa que no pasa desapercibida a Platón mismo), ya que, por ser un mero parecer de la apariencia (alejado por ello tres grados por debajo de la realidad misma), pretende volcarlo todo, y elevarse ella como única aparición. Con todo ello, y con su peligro, Sócrates no la elimina como posibilidad, al menos de modo provisional, como veremos más adelante. Mas sin embargo le concede un lugar por debajo del relato simple, es decir, de aquel que no necesita de simular nada ni nadie, limitándolo en su extensión y por supuesto en sus objetos, así, el tipo de relato que se considerará

72. Ibíd. 396d-e. El subrayado es nuestro.

73. Ibíd. $602 b$. 
óptimo será el mixto, que corresponde al estilo de la épica:

-Por consiguiente, usará [el poeta] el tipo de narrativa que describíamos hace unos momentos a propósito de los versos de Homero, y su modo de relatar participará tanto de la imitación como de la narración simple, pero la parte de imitación será breve dentro de un texto extenso. ${ }^{74}$

Está, pues, ya formado el poeta que se dedicará a contar mitos para la formación de los guardianes, un poeta que ante todo será austero, menos agradable que el imitador estricto y que se conformará con las anteriores pautas que se han establecido en cuanto a la manera y el contenido y extensión de su imitación. La pregunta que surge es entonces ¿y de dónde se sacará tal poeta?, ¿se formará también como un guardián del Estado, o artesano de la libertad del Estado, o será otra especie de artesano dedicado exclusivamente a contar mitos? Esto no lo resuelve Sócrates (parece que tampoco Platón mismo) y, sin embargo, uno puede pensar que si bien los guardianes podrán hacer ese tipo de imitaciones como mero pasatiempo, no serán los mismos que se dedicarán a contar mitos a los niños para su educación. La razón radica, y aquí parafraseamos a Platón, en que la naturaleza humana no podría ya ser más desmenuzada en partes más pequeñas ${ }^{75}$, tampoco podría desdoblarse ni multiplicarse ${ }^{76}$, por consiguiente,

...si hemos de mantener nuestra primera regla, según la cual nuestros guardianes debían ser relevados de todos los demás oficios para ser artesanos de la libertad del Estado en sentido estricto, sin ocuparse de ninguna otra cosa que no conduzca a ésta, no será conveniente que hagan o imiten cualquier otra. ${ }^{77}$

Así, cualquier otro poeta que se desdoble (diplóu) o se multiplique (pollaplóus), será alguien que, por no adecuarse a la ya establecida organización política, deberá elogiarse por "maravilloso y encantador" en cuanto a sus poemas, pero despedido a otro Estado por hechicero y embaucador. Estos guardianes no podrían imitar sino aquello que atañe a lo suyo, esto es, a la libertad del Estado, so pena de pasar como un trasgresor del propio Estado, tal como el poeta que, al cantar sus mitos (en tanto discursos falsos), propaga su epidemia insana a la ciudad. Si bien entra a la ciudad como un dios, se le despedirá como miasma. Así, pues, dice Sócrates se le ungirá

\section{Ibíd. 396e. \\ 75. Ibíd. 395b. \\ 76. Ibíd. $397 \mathrm{e}$ \\ 77. Ibíd. 395c}


mirra en la cabeza (ungüento exclusivo para reyes o dioses) y además se le coronará con cintillas de lana ${ }^{78}$ para luego expulsarlo del Estado (¿será alguna referencia a la fiesta de las Targelias en las que se llevaba el eiresione, ramo de olivo o de laurel con cintas de lana, que llevaban los hiketeríai, ramos de suplicantes coronados de lana, rito asociado a la expulsión del phármakos?).

-De ese modo, si arribara a nuestro Estado un hombre cuya destreza lo capacitara para asumir las más variadas formas y para imitar todas las cosas y se propusiera hacer una exhibición de sus poemas, creo que nos prosternaríamos ante él como alguien digno de culto, maravilloso y encantador, pero le diríamos que en nuestro Estado no hay hombre alguno como él ni está permitido que llegue a haberlo, y lo mandaríamos a otro Estado, tras derramar mirra sobre su cabeza y haberla coronado con cintillas de lana. ${ }^{79}$

Todo parece indicar que es algo así como un rito de ostracismo, de expulsión de un mal, tal como se daba en las Targelias con la figura del Phármakos. No se trata, pues, de un mero juego de niños, se trata precisamente de un mal, de un miasma que hay que eliminar. Es necesario, entonces, comprender la razón por la cual la imitación, en tanto mentira expresada en palabras, puede ser utilizada como un remedio que, dependiendo de la manera como se utilice, puede volverse también veneno. De esta mentira útil, Sócrates va a hacer uso de ella para contar un mito, del que teme no sea lo bastante persuasivo como para creerse y el cual explica el porqué los guardianes deben amar el Estado del que surgieron, defenderlo como a una madre o nodriza, y ver en sus compañeros de armas como a unos hermanos. Este mito es tradicional en la literatura griega y narra la fundación de Tebas por Cadmo a partir del nacimiento de los guerreros que surgen de la madre-tierra y que ella misma los dotó tanto de sus armas, como de todos sus demás enseres. Lo que llama la atención de este mito, que está dirigido a la formación de los gobernantes y militares, es que Sócrates vacile en encontrar la manera adecuada de persuadirlos de que todo lo dicho en su anterior educación eran cosas que les sucedían solo en la imaginación o en sueños, pero que aun así, habían estado realmente en el seno de la tierra y allí mismo fueron formados. ¿Se trataría, pues, de aquella tercera prueba de hechicería en la que se contemplaría a los gobernantes mismos para determinar su grado de convicción, "según la cual

78. Cfr. Vernant, Jean Pierre y Vidal-Naquet, Pierre. Mito y tragedia en la Grecia Antigua. Tomo I. Madrid. Taurus. 1987. Pág. 121 y ss.

79. Platón. República. Op. Cit.398a. 
se debe hacer siempre es lo que piensan que es lo mejor para el Estado"80? Lo que tratamos de decir es que luego de que estos hombres sepan que su educación fue por medio de cosas que no sucedían más que en su imaginación o en sueños (provoca decir, que su educación se basó en el engaño) ¿cómo podrían seguir con aquella convicción de hacer lo mejor para el Estado, luego de haber oído el mito de los hombres-nacidos-de-la-tierra, que es otro mito más?, el mito como mentira expresada en palabras es un engaño, por lo tanto un hechizo más, pues "todo cuanto engaña hechiza" ${ }^{81}$, así que esta tercera prueba de fuego corresponde a que, a pesar de este "orden engañoso de las palabras", el gobernante siga con la convicción que el Estado espera de él

_Y habrá que crear una tercera especie de prueba, una prueba de hechicería, y contemplarlos en ella. Así como se lleva a los potros adonde hay fuertes ruidos y estruendos, para examinar si son asustadizos, del mismo modo se debe conducir a nuestros jóvenes a lugares terroríficos, y luego trasladarlos a lugares placenteros. Con ello los pondríamos a prueba mucho más que al oro con el fuego, y se pondría de manifiesto si cada uno está a cubierto de los hechizos y es decente en todas las ocasiones, de modo que es buen guardián de sí mismo y de la instrucción de las Musas que ha recibido, conduciéndose siempre con el ritmo adecuado y con la armonía que corresponde, y, en fin, tal como tendría que comportarse para ser lo más útil posible, tanto a sí mismo como al Estado. ${ }^{82}$

Vale la pena resaltar la alusión que Platón hace de la "instrucción de la Musa”, pues revela que la inspiración no ha sido abandonada y, al contrario, se yergue como garante de su fortaleza. Debemos pensar, entonces, que este tipo de mito no está exento de inspiración, o, lo que es igual, de realidad. ${ }^{83}$ Así tenemos que el mismo mito puede ser tomado como remedio contra el mismo hechizo, se trata de una vieja fórmula alquímica, en la cual lo igual se une con lo igual, o bien, con una variante, lo igual se enfrenta con lo igual: un mito combate otro mito. Sabia fórmula de neutralización de un mal: el mismo mal, es el remedio, la cura y purificación de la mácula que provocó.

80. Ibíd. $413 \mathrm{c}$.

81. Ídem.

82. Ibíd. 413d-e.

83. Como se constata en el libro III, 682a de Las Leyes, la inspiración divina se alza como garante de la realidad del relato. 
De esta manera concluimos con la consideración del libro III de la República, mostrando la manera en que el mito puede ser noble si es utilizado para provocar en el alma de guardianes y gobernantes aspiraciones virtuosas que vayan en beneficio del propio Estado y de sus miembros. También puede el mito ser útil si sirve como remedio para proteger al hombre de los hechizos con que los imitadores, sean poetas, sean sofistas, acechan el alma de los guardianes. Este mito fenicio de los hijos-de-la-tierra sería el ejemplo de cómo lo anterior puede ser posible, además de que ilustra de manera muy austera y en estilo de relato simple un mito de contenido estrictamente moral y pedagógico. En lo que resta de este estudio, dedicado a la mimesis, no nos queda considerar sino el libro $\mathrm{X}$, donde se hace la crítica decisiva a la imitación como tal. Si bien en el libro III aún no se descartaba la imitación como posibilidad de educación, en este último no se admitirá en absoluto tal como se había tomado desde entonces por los poetas y el público.

\section{Libro X: La crítica de la mimesis}

La tercera parte de este estudio la centraremos entonces en las razones de este absoluto rechazo a la mimesis por parte de Sócrates a raíz de la teoría de las Ideas. Esta visión estará complementada con algunos apartes del Sofista, donde se hace mención también de la naturaleza de la mimesis y del mimetés. Por su parte, los pasajes que se tendrán en cuenta para el libro X abarcarán del 595a, hasta el 608b.

Ya al principio de este escrito se había hecho una breve consideración de lo que es la mimesis, como imitación de la apariencia, y de la presunción del poeta de abarcar todos los saberes en su obra y elevarse por ello como paradigma de sabio, por tanto, como óptimo y único educador (aparte del sofista, claro, pero se entiende que son prácticamente lo mismo). Homero se alza, entonces, como la cabeza principal de los poetas en general, incluidos los trágicos, pues por ser su primer maestro y guía (595c), es por eso mismo padre de todos ellos. Pero antes de estudiar la crítica a Homero, recordemos el lugar y la naturaleza que le confiere Sócrates a la mimesis. Hay ante todo tres maneras de aparecer de las cosas: la primera es la realidad de la misma, que tiene que ver con su Idea, creación exclusiva del "productor de naturalezas", es la Idea en sí del objeto a considerar. La segunda aparición es la que hace el "artesano", que si bien no fabrica la Idea en sí, dirige su mirada a la misma y hace un objeto particular, semejante a lo real, mas no es lo real (597a). Y finalmente la aparición de ese objeto se da en el imitador (mimetés) que simula o representa el objeto desde su parecer y no desde su realidad, que sin embargo debe entenderse como la naturaleza (phýsis) en tanto su ser en sí. En pocas palabras, el imitador no dirigirá su mirada a la Idea (idéan), sino a lo que semeja esta idea en su concreción particular, para darnos no una copia de ella, sino meramente un único aspecto de entre la multiplicidad de sus facetas. Se trata de un mero simulacro. Esta parcialidad 
de la mirada del pintor o del mimetés en general es aquello que Sócrates menciona como imagen (eídolon) de la totalidad de la cosa en sí que imita, y que elige de ella solo un poco de su aparecer (recordar lo dicho en el pasaje 598b).

Así, como solo se ocupa el imitador de este poco que está representado en la imagen, y además por que lo que representa no es la realidad (alétheia), sino una manera de su aparecer (phaíno) de lo que aparece (to phainómenon), entonces el imitador no se dedica más que a la apariencia (phantásmata) de esto que aparece en su concreción. Aquí hacemos el enlace con Homero y sus secuaces, en tanto Sócrates los ha definido como "imitadores de imágenes de la excelencia". Esta definición da cuenta de la peculiaridad del tipo de imitación que le corresponde a la poesía, pues se dedicará al retrato de personajes no ya en su aspecto físico, como le correspondería a un pintor, sino a la calidad de las acciones que lleva a cabo, es decir, la poesía imitativa, en especial la tragedia, tiene como finalidad representar acciones en tanto virtuosas, esto es, en tanto sean obras voluntarias o forzadas. ${ }^{84}$

No sobraría mencionar que esta areté que Sócrates refiere aquí como propia de Homero y el resto de los poetas, es una excelencia que no tiene nada que ver con la realidad misma de la excelencia, que se concibe como Idea y que ya se había mencionado en el libro II con referencia a los parámetros en los que el poeta debe ceñirse para hablar de los dioses y héroes. Por ello, la imagen de la excelencia que nos dan los poetas no es de confiar, pues no se toma de la realidad de la misma en cuanto Idea, sino en cuanto apariencia (parcial) de un aparecer de la Idea.

Para ilustrar mejor la diferencia de esta imagen con respecto a la Idea misma, recurriremos de nuevo a los pasajes del Sofista comprendidos entre 265a y 267e. Lo que queremos indagar es cómo se produce esta "imagen de la excelencia" a diferencia de las imágenes de los objetos, es decir, ¿De qué manera se produce este tipo de imagen que el poeta toma de los héroes y los dioses que le sirven como modelo para representar esta imagen de la excelencia? Empecemos diciendo que esta "imagen de la excelencia" es un resultado de la eidolopoiiké o "producción de imágenes", propia de la naturaleza humana. Sin embargo, esta poíesis no es igual a la eidolopoiiké divina, pues esta produce no solamente las realidades en su esencia, en su ser en sí, esto es, la autopoietiké, sino también, las imágenes de estas realidades (eidolopoiiké). No debemos pensar, empero, que la imagen, solo por ser imagen, es propia de la naturaleza humana. Pues bien, la representación de las cosas en su realidad es producción divina, no humana. Este tipo de imagen no es engañoso (pues la divinidad no miente), esto es, la realidad aparencial de la cosa en sí no tiene por qué engañarnos, pues acompaña a la realidad (ello no excluye que podamos

84. Ibíd. 603c. 
hacernos una idea errónea de las mismas, a causa de nuestra percepción). No obstante, la imagen que produce el hombre en la imitación, por ser tomada de una producción humana, o bien de una imagen de la misma naturaleza, no puede ser más que engañosa, pues no toma su imagen directamente de la Idea original. Esto se entiende perfectamente para los ejemplos que Platón ofrece para el pintor: objetos artesanales, personas, cosas, en general, pero para las acciones humanas como los actos virtuosos, por ejemplo, ¿en qué otra clase de apariencias el poeta se basa para producir tales imágenes de la excelencia si no es en las propias acciones humanas que luego el pensamiento y el discurso de las mismas llegan a representárselas a su alma? ¿Pero no es esto precisamente lo que Sócrates en el libro II ataca en los poetas? ¿No deben tomar su modelo de la propia Idea de la virtud y no simplemente de los actos humanos que son mera copia de la realidad? ¿Puede el poeta llegar a conocer tales realidades? Y de ser así ¿Cómo las representaría? Aquí es precisamente donde hace su aparición de nuevo el problema del conocimiento y de la ignorancia. En efecto, al haber distinguido el Extranjero dos clases de producción, la divina y la humana, e igualmente derivar de cada una de las dos anteriores la producción de una parte de las cosas mismas, y la producción de las imágenes de esas cosas por la otra, se hace una tercera división que corresponde a la producción de imágenes, en cuanto que esta tiene dos formas, una como figurativa, y la otra como simulativa ${ }^{85}$. A esta última se le da el nombre de técnica imitativa y así mismo se divide en dos, una técnica en la cual se imita con conocimiento, y la otra sin conocimiento.

Extr._ Entre los que imitan, algunos conocen lo que imitan y otros no. En consecuencia, ¿qué mayor división podríamos proponer que la ignorancia y el conocimiento?

Teet._ Ninguna.

Extr._ La imitación que poco antes mencionamos, ¿era acaso la de quienes saben? Pues si alguien quisiera imitarte, bien podría conocerte a ti $y$ tu aspecto.

Teet._ ¿Y como no?

Extr._Pero ¿qué pasa con el aspecto de la justicia y, en general, de toda perfección? ¿ No ocurre que, sin conocerlas, y apenas con una cierta opinión de ellas, hay muchos que intentan producir esas semejanzas en ellos mismos, esforzándose en mostrar que están presentes en su interior, imitadas especialmente por hechos y por palabras?

85. Platón. Sofista. Madrid. Gredos. 264c y 266d. 
Teet._ Hay muchos, sí.

Extr._ ¿Acaso fracasan todos los que quieren mostrar que son justos, cuando en realidad no lo son? ¿O es todo lo contrario?

Teet. _ Todo lo contrario. ${ }^{86}$

Si bien todo el contenido de esta distinción está orientado a dar una definición del sofista, nada nos impediría aplicarlo a los poetas. En el anterior pasaje podemos notar que habría una imitación de aquel que sabe y que luego llamará Sócrates "imitación erudita", pues está acompañada de ciencia, y la otra "imitación conjetural", que está acompañada por la opinión de aquel que no sabe, esto es, del ignorante. Del imitador erudito, el extranjero insinúa un ejemplo que se acomodaría a esta circunstancia, de tal manera que aquel que quisiera imitar al propio Teeteto, tendría que primero conocerlo a él mismo y su aspecto [267b]. Ahora bien, con respecto al imitador conjetural lo podemos ubicar en aquellos que tratan precisamente de imitar la justicia y la perfección (areté), sin conocerla. Aquí se ubican todos los poetas con su adalid, Homero, a la cabeza. Retomemos entonces nuestra argumentación. Pareciera ser que los productores de "imágenes de la excelencia" se ubican en los imitadores por conjeturas que no saben ni de la justicia ni de la perfección y solo tienen una opinión (dóxa) de la misma.

La poesía pues, como pura opinión. Al respecto Eric A. Havelock, en su libro "Prefacio a Platón" 87 le dedica un capítulo entero al problema de la poesía como opinión, analizando los libros II, III, V, VII y X de la República. El citado autor hace mención del término dóxa como sinónimo algunas veces de sensibilidad (aisthésis) libro VII, y más adelante, en el libro X, como mimesis. El sentido que Havelock le da al término hace referencia a una "mentalidad no abstracta", en la cual no sería posible percibir ni las entidades abstractas puras, ni tampoco aprehender las abstracciones morales $^{88}$, y por ello mismo, por esta incapacidad de discernir unas cosas de otras (lo abstracto de lo concreto), surge la contradicción propia del poeta, en la cual un mismo personaje puede ser y no ser, como el caso de Agamenón que a veces y dependiendo de las circunstancias, es noble e innoble:

Así, en el libro X, cuando Platón argumenta que el artista es un hombre de opinión, que confunde las dimensiones sin acudir a la razón ni al cálculo, y que se ocupa de apariencias físicas caracterizadas por el hecho de ser y no ser al mismo tiempo, lo

86. Ibid. 267b-c.

87. Havelock, Eric A. Prefacio a Platón. Barcelona. Visor. 1994. 286ps.

88. Ibíd. Pág. 231. 
que está haciendo es aplicar las doctrinas de los libros V y VII, reduciendo la enfermedad radical de la poesía a esta especie de contradicción. Pero ésta no será tal enfermedad si no partimos del supuesto de que la realidad no está en los hechos y situaciones inmediatas, sino en las abstracciones aisladas, como grandeza y pequeñez o justicia e injusticia ${ }^{89}$.

La opinión, en el contexto de este autor, es ante todo una mentalidad concreta y por ello contradictoria, de tal suerte que "poco falta para que la contradicción se nos presente como principio básico de la poesía" ${ }^{\text {" }}$, contradicción que se opone a la condición misma de todo saber. Valga la pena mencionar el carácter totalizador, y por ello abstracto, que implica el saber, en contraste con el carácter parcializado, y concreto de la opinión. Recordemos que la palabra dóxa viene de dokéo, parecer, en tanto es parecer de un aspecto, no de su totalidad; así, pues, opinión (en una de sus acepciones) es igualmente apariencia (phantásmata), pero en el caso de la poesía es una apariencia no de una cosa o realidad particular (apariencia de Edipo en tanto hombre), sino de un problema de orden humano o cognitivo (p.e. Edipo muda de ignorante de su destino, en sabedor del mismo), por lo tanto, discutible (en el sentido de ponerse en discursos), en definitiva, la apariencia de un saber. Habíamos mencionado arriba la posibilidad de ubicar a los poetas entre aquellos que imitan por conjeturas, por lo tanto, podríamos definir la poesía como una mera opinión. Sin embargo parece ser que en el libro X de la República, se le niega al poeta incluso la posibilidad de tener algún conocimiento sea este real o sea aparencial en tanto dóxa:

-En cuanto al imitador, ¿a partir del uso será que posee conocimiento acerca de si lo que pinta es bello y recto o no? ¿Acaso tendrá una opinión correcta debido a la relación forzosa con el entendido y por haber sido instruido por él sobre cómo pintar?

-Ni una cosa ni la otra.

-El imitador, por ende, no tendrá conocimiento ni opinión recta de las cosas que imita, en cuanto a su bondad o maldad. ${ }^{91}$

¿Podrá tratarse de dos tipos de doxai diferentes? Una doxa que es ignorancia, esto es, un no saber con pretensión de conocimiento, tal como se nos presenta en el

89. Ibíd. Pág. 230.

90. Ibid. Pág. 228.

91. Platón. República. Op. Cit. [602a] . 
Sofista; la otra doxa que, si bien no es el propio conocimiento, puede al menos tener una "opinión correcta" del asunto por el cual se es instruido, esto es, una visión parcial pero recta del objeto como tal, en su aspecto concreto y que sería propio del conocimiento de las téchnai. En todo caso, en este contexto, el poeta no puede llegar siquiera a una opinión recta del asunto que imita. En pocas palabras, es imposible llegar a tener un conocimiento recto en cualquier aspecto, desde la imitación. ¿Cómo entonces Platón soluciona el hecho de que los poetas aparezcan como educadores sino tienen nada para enseñar? ¿Cómo explica el hecho de que puedan componer (poiein) si ello no es posible sin conocimiento? ¿Cómo Platón "desenmascara" a los poetas en cuanto se dicen conocedores de todo lo divino y humano? iLe hace este desenmascaramiento justicia a los poetas? Empecemos por las primeras dos preguntas.

La manera como Platón soluciona la aparente aporía de que los poetas, que no tienen conocimiento en absoluto, puedan ser considerados como educadores, está dada por la imagen que se tiene de ellos como hechiceros y encantadores capaces de engañar el alma de aquellos que los escuchan, haciéndoles creer que son conocedores de todo lo que dicen, similar a como se produce en nuestra alma el tipo de perturbación que ocurre cuando las cosas vistas a través del agua nos parecen curvas o rectas, según estén dentro o fuera del agua. ${ }^{92}$

Con el símil de la pintura, Platón explica la manera en que la mimesis poética hechiza el alma de los incautos, es decir, de aquellos que no poseen aún el antídoto para contrarrestar el efecto de su hechizo. Como se trata ahora de otro medio, la palabra, entonces el encantamiento que producía la pintura con sus colores y figuras será sustituido por el metro, el ritmo y la armonía de las palabras y las frases que el poeta pueda formar con ellas. Pero vale la pena recalcar que, a pesar de que el poeta se vale de aquellas en su habla para referir cosas o situaciones concernientes a una téchne, por ejemplo, no quiere decir por ello que tenga conocimiento de la misma y sí solo un conocimiento aparente, que no llega a ser ni siquiera una opinión. En este caso el poeta nos colorea (chrómata) esta téchne a partir de las palabras mismas en tanto puestas en medida, ritmo y armonía, mostrándonos solo una ilusión (phantásma) de la misma:

_Así también se me ocurre, podemos decir que el poeta colorea
cada una de las artes con palabras y frases, aunque él mismo sólo
está versado en el imitar, de modo que a los que juzgan sólo en
base a palabras les parezca que se expresa muy bien, cuando, con
el debido metro, ritmo y armonía, habla acerca del arte de la

92. Ibíd. 602d. 
zapatería o acerca del arte del militar o respecto de cualquier otro; tan poderoso es el hechizo que producen estas cosas. Porque si se desnudan las obras de los poetas del colorido musical y se las reduce a lo que dicen en sí mismas, creo que sabes el papel que hacen, pues ya lo habrás observado. ${ }^{93}$

Este desnudamiento (gymnósis) que realiza Sócrates del discurso de los poetas, dejando ver la fragilidad del mismo sin el adorno del metro, ritmo y armonía, esto es, de su colorido musical (mousikés chromatón), es el tipo de desenmascaramiento que Platón efectúa de los poetas. De este "desnudamiento" ya tuvimos referencias en el pasaje 393e, donde Sócrates "por no ser poeta" relata en prosa el pasaje de Homero relativo al episodio en el que Crises le pide a Agamenón le devuelva a su hija Criseida. Platón ya no se cuidará siquiera de cuestionar la verdad o la falsedad de lo que digan los imitadores (excepto de los sofistas, ahí, tal vez, radicaría la diferencia entre ellos y los poetas), sino tan solo de quitarles el ropaje y los adornos tan caros a los poetas en general, para quedar en nada el objeto mismo de su discurso. Despojar al discurso (diánoia) de toda mimesis, de todo adorno, es quitarle el encantamiento (kélesis) que provoca en el alma de los oyentes ingenuos. No se trata aquí de oponerle al discurso poético un discurso dialéctico, no se trata tampoco de utilizar la persuasión. La operación de desnudamiento consiste únicamente en despojar al discurso poético de todos sus adornos y artificios miméticos, para corroborar que detrás de ese espléndido ropaje no hay más que un vacío, una nada, un mero espectro que se dispersa como el humo, luego de que el fuego de la poesía fuese sofocado por el phármakon del Lógos. El poeta, en última instancia no conoce la verdad, pues de conocerla, nos dice Sócrates "se esforzaría por las cosas efectivas mucho más que por sus imitaciones" ${ }^{\text {" }}$, de ahí, que el estatuto de la verdad esté orientado hacia aquellas cosas efectivas llamadas Ideas, y no en vano llamadas por Sócrates naturalezas (phýseis), esto es, entidades que hacen efectivas sus manifestaciones, sin mediaciones ${ }^{95}$, prestas y diligentes (spoudaioi) tal como el ojo con respecto a

93. Ibíd. 601a-b.

94. Ibíd. 599b.

95. Este "sin mediaciones" lo tomamos en el sentido de la contemplación directa que parece indicarse en la lectura de la palinodia del Fedro (250c y ss), en la que el alma del filósofo contempla las celestiales visiones. Es cierto que la idea se manifiesta no de manera inmediata, sino a través del largo ejercicio dialéctico. Ejercicio, que, sin embargo se da en nuestra vida mortal y que por él accedemos de nuevo a aquellas visiones que antaño, cuando teníamos alas, nos fueron allí dadas de manera diáfana y pura. Es cierto también que, como lo anota el profesor Jairo Escobar en el presente trabajo, se "sobrevalora el mito cognoscitivo del Fedro, y lo desgaja del contexto dialéctico del cual está inserto". Al respecto no tenemos cómo salir incólumes ante tal observación, solo que con ello hemos querido enfatizar parte de nuestra tesis, a saber, que Platón, como poeta-legislador, recurre a los mitos órficos para reescribir de nuevo los dioses, lo divino, y para que, de lo infundable de este dominio, surja la posibilidad de una verdadera mimesis-representación. 
su objetivo. El poeta está lejos, pues, de tal inmediatez. La tragedia sería, en este sentido, ese espejo con el que un cierto tipo de demiurgo simula producir con rapidez la inmediatez y efectividad con la que el phitourgós produce las naturalezas ${ }^{96}$. Lejos de esta realidad está el trágico, en la que su composición vuelve a resonar el aspecto pueril y lúdico, apareciendo, de esta manera, bajo un aspecto vacuo, e irreal:

_Después de esto debemos examinar la tragedia y a su adalid, Homero, puesto que hemos oído a algunos decir que éstos conocen todas las artes, todos los asuntos humanos en relación con la excelencia y el malogro e incluso los asuntos divinos. Porque dicen que es necesario que un buen poeta, si va a componer debidamente lo que compone, componga con conocimiento; de otro modo no será capaz de componer. Hay que examinar, pues, si estos comentaristas, al encontrarse con semejantes imitadores, no han sido engañados, y al ver sus obras no se percatan de que están alejadas en tres veces de lo real, y de que es fácil componer cuando no se conoce la verdad; pues estos poetas componen cosas aparentes e irreales. O bien, si tiene algo de peso lo que afirman tales comentaristas, los buenos poetas conocen realmente las cosas que a la mayoría le parece que dicen bien. ${ }^{97}$

El verdadero acto de componer (poiein) es aquel que se realiza con conocimiento (eídos) de lo real, esto es, no un imitar, sino un producir efectivamente aquellas realidades que participan de manera directa y no mediata de la verdad. El mimetés no es imitador siquiera de las naturalezas, sino de las obras de los artesanos o de las acciones humanas, y no como son, sino como aparecen (phaínestai) y no de manera que abarque todas sus posibilidades de aparición, sino tan solo un aspecto o ángulo de ellas ${ }^{98}$. Así, el imitador, solo imita la apariencia (phantásmata), y de ella un solo aspecto, no la realidad (alétheia) en su totalidad. Pero así como vimos que el poeta no tiene conocimiento de la verdad, el siguiente paso lo da Platón mostrando que tampoco tiene recta opinión de aquello que imita, es decir, ni aún en lo referente a la opinión, el imitador puede tener la última palabra. Esto lo hace evidente en la división que realiza de las artes en cuanto a cada cosa: el que las usa (chresoménen), el que las hace (poiesousan) y finalmente el que las imita (mimésomenen) ${ }^{99}$. De los

96. Platón. República. 596d-e.

97. Ibíd. 598e-599a.

98. Ibid. 598 a.

99. Ibíd. 601d. 
tres, el que hace uso de las cosas, es el más experimentado. El fabricante, por su parte, tendrá una

...recta opinión en lo tocante a su bondad y maldad, debido a su relación con el entendido, y al verse obligado a atender al entendido, en tanto que éste, que es quien usa el objeto, es el que posee el conocimiento. ${ }^{100}$

Y en tanto el poeta no tiene ni conocimiento (epistéme), ni opinión (dóxa) correcta de las cosas, entonces no le queda más que la imitación, ya que de cada cosa no es capaz de distinguir ni su bondad ni su maldad, y así, saca su saber de la nada y cautiva a la multitud ignorante gracias al modo como dice las cosas, tratando de imitar, si acaso, lo que pasa por bello para estos. Y esta es la razón por la cual su saber no puede ser tomado en serio, sino solo como un juego o pasatiempo en el que de manera rápida e irresponsable se asume la seriedad de la vida y sus realidades. El poeta, como lo hemos ya subrayado, no posee conocimiento ni de las realidades, ni de las concreciones propias de las technai (que abarcarían tanto su uso como su producción) en las cuales puede y debe haber una opinión correcta. No obstante, ello no impide que los poetas y más concretamente, los trágicos, puedan ser considerados no solo educadores del pueblo, sino incluso como sus gobernantes y estrategas. Recuérdese la parte final del Ion, donde el rapsodo defiende su arte comparándolo con el del estratega por no poder distinguir la efectividad de un oficio y del otro. Ion pensaba que ambas artes se igualaban porque compartían el mismo poder de persuasión de la palabra: la del general a sus soldados y la del rapsodo ante sus espectadores. La pregunta no se hace esperar de parte de Sócrates “ ¿cómo es, pues, que siendo el mejor de los helenos, en ambas cosas, como general y como rapsodo, vas recitando de un sitio para otro, y no te dedicas a hacer la guerra?"101 apunta a que, si son idénticas ambas artes, no habría ningún impedimento en que Ion, como general, se dedicase a la guerra, pues en un Estado habría más necesidad de guerreros o guardianes que de rapsodos propiamente hablando. Esto significa que, identificándose el arte de la estrategia con el arte de la poética, ambas tendrían el mismo grado de efectividad respectivamente. Esta misma crítica se vuelve a mencionar en este libro X, cuando Sócrates cuestiona al propio Homero por aquellos Estados que él gobernó, o en los cuales fue considerado como buen legislador; o bien él mismo le interroga por las guerras que fueron conducidas por su mando. Para ello Sócrates coloca artificiosamente a Homero en el grado de conocedor de aquellas ocupaciones que tornan mejores a los hombres, esto es, la de los gobernantes (dioikétai), la de los

100. Ibid. 602a

101. Ibíd.541b. 
legisladores (nomothetés), y la de los generales (strategós), con el fin de evidenciar lo lejos que está un poeta de ocuparse efectivamente de tales asuntos ${ }^{102}$. De paso, Platón aprovecha un poco para ironizar, tanto en el Ion, como aquí en la República, sobre un aspecto, que, tal vez, coincide con la anécdota que Walter Kaufmann menciona en su libro "Tragedia y filosofía" 103 , con respecto al hecho de haber elevado Pericles a Sófocles a la categoría de "general", luego de estrenar su obra "Antígona", hecho que, si bien no es conforme al oficio de poeta, si revela la profundidad, léase el conocimiento, que Sófocles tenía del hombre:

A este respecto será bueno recordar que nombraron general a Sófocles junto con Pericles, inmediatamente después del estreno de Antígona, debido a que los atenienses se impresionaron enormemente de su obra; pero esto mismo nos enseña cuán lejos va Platón en su crítica. En cierto modo, la tragedia de Sófocles es una pura semejanza de una acción, pero también es una visión profunda de la condición humana con una riqueza introspectiva que iguala e incluso sobrepasa la sabiduría de Platón.

Esta visión de la condición humana que Kaufmann le atribuye a Sófocles es el punto de partida para mostrar que en la tragedia sí sería hereditaria de un tipo de sabiduría, de conocimiento, que no tiene que ver con el saber eidético, pero tampoco con el saber concreto de las técnicas, sino que se remonta a un saber extático muy emparentado con la sabiduría que obtenían los seguidores de Orfeo y que Platón les negó sistemáticamente.

Pero retornemos al asunto que nos ocupaba, con respecto al interrogatorio al que Sócrates somete a Homero. Luego de suponer a este como gobernador, legislador y estratega, e interrogarlo por lo efectivo de su acción, pasa a cuestionarlo como sabio en cuanto a inventor y después como educador. En efecto, Sócrates se pregunta si como educador en la excelencia de los hombres, tuvo por suerte discípulos que inauguraran una escuela que los distinguiera de todas las demás, o que mínimamente lo hubieran obligado a vivir entre ellos y no lo hubieran dejado salir y deambular de ciudad en ciudad como acostumbraban los rapsodos y poetas en general, hasta que les enseñara todo lo que sabía ${ }^{104}$. En fin, que los poetas, comenzando por Homero, solo son "fabricantes de imágenes", sea de la excelencia, sea de las otras cosas que cantan. Hemos visto, hasta ahora, dos críticas contundentes a los trágicos: la primera de ellas relativa a la vaciedad de lo que dicen en sí mismos sus discursos, cuando se

102. Este aspecto político lo consideraremos más adelante en el ensayo "mímesis, inspiración y política".

103. Kaufmann, Walter. Tragedia y Filosofía. España. Seix Barral. 1978. Pág. 49.

104. Platón. República. Op. Cit. 600b-e. 
les desnuda del ritmo, de la armonía y del metro, esto es, de su colorido musical. El segundo argumento es el relativo a la ausencia de efectividad en el acto creativo del poeta, pues ni siquiera estaría a la altura del artesano o de aquel que gobierna o dirige un pueblo. Como tercer elemento que pasaremos a considerar como parte de esta crítica platónica a la mimesis será a un nivel estrictamente ético, es decir, al nivel en el cual el hombre debe comportarse y asumir su destino conforme a la razón.

Ya habíamos mencionado el elemento contradictorio de la poesía que parecía manifestarse como la base de la poesía misma en tanto en ella es posible encontrar dos opiniones de distinta naturaleza que coexisten simultáneamente. Es aquí donde tomamos distancia de este autor cuando sostiene la idea de que la poesía es opinión, debido a que esta "es aquella que continuamente aprehende el ser y el no ser"105, pues se establece como punto intermedio entre el conocimiento y la ignorancia. Ya hemos visto, sin embargo, que el contexto de la opinión en este libro está enmarcado en la mentalidad de las cosas concretas, esto es, en aquellas elaboraciones propias de los artesanos que tienen para sus oficios una opinión correcta. En este contexto, pues, Platón no hace referencia a esta "mentalidad concreta" propia de la doxa, en términos negativos, es decir, no en términos de contradicción, como lo propone Havelock "el error radical de la mentalidad concreta es precisamente la contradicción. Estamos ante una arma dialéctica"106. De hecho esta "arma dialéctica", es la que permitirá enfrentar y eliminar de por sí la contradicción propia del azar, y por ello Sócrates se valdrá del antídoto de la razón que "confía en la medición y el cálculo" y que se toma como la mejor parte del alma, en contraposición del arte mimético al que le corresponde la parte inferior de la misma. De lo que se trata ahora es de saber si a la parte de la imitación que concierne al oído, es decir, la poesía, se le puede aplicar también esta valoración y de qué manera. Para ello Sócrates define la poesía imitativa como aquella que "imita a hombres que llevan a cabo acciones voluntarias o forzadas, y que, a consecuencia de este actuar, se creen felices o desdichados". Entramos en el terreno, pues, de la ética, esto es, del comportamiento (éthos) humano, pues se trata de demostrar que la poesía imitativa como correlato de la pintura, y en general de todo arte imitativo, se ocupa de la parte inferior del alma y no de la mejor. Más adelante dirá Sócrates que esta poesía imitativa se dedicará a imitar la parte irritable y voluble del alma, fácil de imitar, pues se aleja de la realidad del alma que tiende por naturaleza a su parte racional. Platón no ignora la condición humana presa de múltiples "contradicciones que se suscitan al mismo tiempo"107 generando en el alma

105.Havelock, Eric. Prefacio a Platón. Op. Cit. Pág. 228.

106. Ibíd. Pág. 228

107. Platón. República. Op. Cit. 603d. 
una lucha interior contra sí misma en torno a los mismos objetos. Platón, por esto mismo, no ignora que los poetas trágicos problematizan esta faceta humana desde aquello que el hombre es incapaz de controlar: su destino. Así también describe Vernant ${ }^{108}$ la polaridad de la acción trágica: como un juego del que el hombre no es dueño y en el que siempre corre con el riesgo de caer en la trampa de sus decisiones:

En la perspectiva trágica, obrar comporta por tanto un carácter doble: es, por un lado, tomar consejo en uno mismo, sopesar los pros y los contras, prever al máximo el orden de los medios y los fines; por otro, es contar con lo desconocido y lo incomprensible, aventurarse a un terreno que sigue siendo impenetrable, entrar en el juego de las fuerzas sobrenaturales de las que no se sabe si al colaborar con nosotros preparan nuestro éxito o nuestra perdición. En el hombre más previsor, en la acción más pensada conserva el carácter de una aventurada apelación lanzada hacia los dioses, y que sólo por su respuesta se sabrá, la mayoría de las veces a expensas propias, lo que valía y lo que quería decir exactamente.

De todas maneras Platón, en boca de Sócrates, propugnará por que en la tragedia la representación que se hace del hombre convenga con la parte superior de su naturaleza, aquella que mide, cuenta y pesa, en resumen, aquella que corresponde con el alma razonada y posee el antídoto contra tales perturbaciones.

Este "carácter sabio y calmo, siempre semejante a sí mismo", es por el contrario más difícil de imitar debido a que corresponde con la realidad del lógos, elemento ajeno a la imitación misma. Aquí surge una inquietud con respecto al tratamiento que le da Platón a la poesía en cuanto si al ya habérsele desnudado de su colorido musical, no se ha hallado en ella nada digno de mencionarse siquiera, ¿por qué entonces se insiste en oponer el lógos a lo que el poeta menciona en sus discursos, si son "como niños, que, tras haberse golpeado, se agarran la parte afectada y pasan el tiempo dando gritos"109? ¿No es más consecuente con la naturaleza del phármakon atacar el veneno con sus propios componentes, esto es, a partir de mitos que superen a los de los poetas tradicionales? Si Platón concibe la poesía imitativa como un juego de niños, que no tiene seriedad alguna ¿por qué, como dice Walter Kaufmann, él mismo se la tomó tan en serio? Es por que precisamente Platón no se toma la poesía tan en broma, y, por el contrario, pareciese como si le quisiera restituir su veracidad en la educación ética del hombre. Ahora bien, una de las maneras como podemos

108. Vernant, Jean Pierre y Vidal-Naquet, Pierre. Op. Cit. pág. 39.

109. Ibid. 604c. 
entender esta posición es que, primero, Platón efectivamente está oponiendo una imitación a otra imitación, esto es, si nos alejamos del discurso filosófico abstracto y recordamos que el estilo de la obra está hecho en base al diálogo, así no se mencionen constantemente los nombres de los que participan, pero que en su forma remite a una dramatización carente de gestos y adornos tales como el metro, la rima y la armonía, no obstante, pues, el estilo nos remite a una manera de imitar, que, efectivamente, rompe con la manera tradicional de imitar los caracteres irritables y variables y se dedica a la imitación de un carácter prototípico como es el del propio Sócrates, sabio y calmo, idéntico siempre a sí mismo. No olvidemos que se trata aquí de un verdadero "teatro filosófico". Como lo segundo, mencionar que este "juego", el de la poesía, no es un juego cualquiera, y menos de cualquier clase de niños, sino que es un juego que remite a unos "niños" en particular: los órficos. Nos remitimos a ellos en esos términos no de manera despectiva, sino, por el contrario, por que en ellos los juguetes, símbolos del infante Dioniso, juegan un papel importante en sus ritos.

Regresando a nuestro asunto de la indagación por la parte del alma que le correspondería tratar a la poesía, Sócrates recurre a la naturaleza humana, plagada de contradicciones y luchas interiores, para mostrar que, aunque este rasgo anterior es propio del alma, no obstante corresponde con la parte inferior y no con la superior donde la razón (lógos) y la costumbre (nómos) induce a resistir (antiteínein) los actos vergonzosos como las lamentaciones y la irritabilidad, en tanto que la parte inferior no hace más que arrastrar al sufrimiento que causan las pasiones ${ }^{110}$. Es este rasgo precisamente el que ve Sócrates como inherente a la actividad del poeta, es decir, es el carácter que el trágico explota en sus obras ya que esta parte irritable del alma "cuenta con imitaciones abundantes y variadas" que favorecen la contrariedad característica del discurso trágico. La parte mejor del alma, su racionalidad, estaría lejos del objeto de la poesía imitativa, pues esta, lejos está a su vez de la verdad, pero muy cerca, eso sí, de los asuntos humanos. Y esto es precisamente lo que más inquieta a Platón, pues el dedicarse a ellos, implicaría de una u otra manera, tratar a fondo el problema de las pasiones y la contrariedad que en el alma suscitan, poniéndola en estado de permanente lucha, lejos de la inmovilidad del Bien:

_Pues bien, en todas estas situaciones, ¿se mantiene el hombre de acuerdo consigo mismo? ¿O bien, como sucedía con la vista, entra en discordia interior y sostiene opiniones contrarias al mismo tiempo respecto de los mismos objetos y se halla así, también en sus actos, en disensión y en lucha contra sí mismo? Pero recuerdo algo que hace que no sea necesario que convengamos en este punto; pues en nuestra argumentación precedente, hemos estado 
suficientemente de acuerdo en que nuestra alma está colmada de miles de contradicciones de esta índole, que se suscitan al mismo tiempo. ${ }^{111}$

Ahora bien, para que no se presente este estado de desorden ético, Sócrates ve la necesidad de que el alma se conduzca a través de la razón, de tal manera que no hay más que obedecerle, para que así ella, al reflexionar sobre lo acontecido, nos lleve "a la curación rápidamente y a levantar la parte caída y lastimada, suprimiendo la lamentación con el remedio" ${ }^{112}$. Y ello estaría en perfecta consonancia con las exigencias del nuevo Estado en el cual no nos podríamos dedicar más que a una sola cosa y esto a la luz de la Idea del Bien. Esta última nos posibilitaría poder diferenciar además una cosa de otra, lo mayor de lo menor, lo grande de lo pequeño y no ponerlas simultáneamente entre las mismas cosas. El poeta imitativo, por el contrario, implantaría un mal gobierno en el alma de cada uno, por exaltar la parte inferior de esta, por poner al alma humana en un estado de total indistinción y contradicción y, finalmente, por echar a perder la parte racional que la curaría de sus infortunios ${ }^{113}$. En efecto, si Platón considera peligroso que el placer y el dolor propios de cada individuo reinen en su Estado en lugar de la ley y la razón que favorece a la comunidad entera, es porque el discurso del poeta trágico no estaría lejos de la proposición sofista de Protágoras : "el hombre es medida de todas las cosas, tanto del ser de las que son, como del no ser de la que no son"114, y por ello, para el hombre que se gobierna a partir de la ley, "ninguno de los asuntos humanos es digno de gran inquietud" 115 . No le queda al poeta más que dedicarse a las realidades inmutables, celebrando a los dioses en himnos y a los hombres buenos en alabanzas ${ }^{116}$ o resignarse al ostracismo, pues los asuntos humanos (que no han sido curados por el remedio de la razón) no generan más que confusión y contradicción en el alma, alejándola de su verdad. ¿No tiene el poeta, pues, otra alternativa? ¿Cómo podría defenderse de su acusador? ¿Les hace justicia Platón a los poetas con su juicio? En efecto, la única manera de defenderse el poeta es que a través de sus cantos estén estos atravesados por un logos, y así poder dar cuenta y razón de su dianoia. Con ello Platón vuelve a abrir la zanja que de antiguo se ha dado entre la filosofía y la poesía, solo que en este

111. Ibíd. 603d.

112. Ibíd. 604c-d.

113. Ibíd. $605^{\mathrm{a}}$.

114. Platón. Teeteto. Madrid. Gredos. 152a.

115. Platón. República. 604c.

116. Ibíd. 607a . 
caso ya no sería, aparentemente, la filosofía aquella "perra gruñona que ladra a su amo [la poesía]", sino, tal vez, más bien lo contrario: que la poesía debería ladrar a su nuevo amo, la filosofía. Y lo decimos en tono condicional, pues en esta confrontación pareciera llevarse la palma de la victoria la filosofía. Sin embargo, para Stanley Rosen $^{117}$, dicha inferencia no es tan evidente. En efecto, la filosofía está asociada con las matemáticas, en tanto la estructura de la Idea está como "constituida por la acción conjunta del Uno y de la ilimitada díada o como poseyendo un estructura interna de elementos monádicos de alguna manera análogos a los números"118, estructura que hace posible que el alma razonada posea el antídoto que "calcula, mide y pesa" y lo aplique contra las obras de los poetas que perturban el alma del espectador. Este antídoto, recordemos, no lo posee más que los guardianes-filósofos, quienes, por esto mismo, "pueden emplear la mimesis, tanto como la poesía mimética, para el beneficio de la ciudad...por que ellos saben lo que están haciendo"119. La función, pues, del alma que razona será regular o controlar el impulso erótico del poeta que desarrolla en el alma la parte inferior, esto es, el deseo, la incontinencia sexual, etc., llevándola a un estado de absoluta tiranía, que, en la República, está asociado al dios Eros $^{120}$. Como hemos venido considerando en este capítulo, el asunto de la crítica platónica a la poesía mimética, no es tanto de orden ontológico o fenomenológico, como político y moral ${ }^{121}$. No es precisamente porque los poetas se valgan de una imagen para representar sus obras por lo que son enviados al exilio. Es porque con esas imágenes le causan perjuicio a la ciudad por no provenir de las Ideas mismas (de los dioses o de los héroes), sino tan solo de las acciones humanas más viles. Si de lo que se trata, en la República, es de la investigación sobre aquello que es "la más grande de todas las cosas, la buena y la mala vida" ${ }^{122}$, entonces es necesaria la ciencia de la dialéctica o del conocimiento preciso de las formas ${ }^{123}$. Así, todo lo que se necesita para la búsqueda de aquella "vida buena", "es una imagen de filosofía en el más estricto, exclusivo, o "matemático" sentido"124. Pero si la filosofía le lleva

117. Rosen, Stanley. The Quarrel between Philosophy and Poetry. Studien. In: Ancient Thought. United States. Routledge. 1988. 221pgs.

118. Ibíd. pág.8.

119. Ibíd. Pág.10.

120. Véase supra nota 2.

121. Ibíd. Pág.9.

122. Platón. República. 578c.

123. Rosen, Stanley. Op. Cit. Pág.12.

124. Idem. 
ventaja a la poesía por su capacidad de explicar el conocimiento, la poesía la aventaja en lo que concierne a su capacidad de producción. El poeta, gracias a su vínculo con Eros, "desea transformar la naturaleza en un artificio o poema"125, pero según su propia imagen, tal como Narciso al mirarse en el reflejo del agua. O mejor aún, como Dioniso que, al verse en el espejo, no aparece él sino el mundo. El filósofo, por su parte, se alzará con la victoria en tanto suprima tal narcisismo y remplace "los espejos con Ideas". Las Ideas, empero, no reflejan, no hay, pues, imágenes de Ideas. Lo que hay son correctas o incorrectas imágenes de Ideas, pero las correctas imágenes no se distinguen de las originales. Ahora bien, estas imágenes correctas de las Ideas se expresan a través de la dianoia que "es la construcción de imágenes discursivas, sobre la base de imágenes no-discursivas u ónticas, de aquellos originales" ${ }^{\text {"26. }}$ La dianoia es productiva, en tanto pone en "conceptos" las formas puras dadas a través del conocimiento noético. Pero aquellos principios que derivan de la intención o actos humanos requieren un elemento mixto. La mimesis, que representa las acciones humanas, por su parte, está reglada por el deseo erótico y no por la inteligencia y el juicio (phronesis) corrompiendo de esta manera la dianoia, que no puede reglarse a sí misma pues es indiscriminada, habla de todo, tanto de poesía como de matemáticas. No basta la mera distinción formal y su juicio, es necesario un "criterio de pureza y así evaluar el significado de las propiedades estructurales en términos de la intención de lo diairético". Este criterio es la "ley" que expresa una intención humana y no meramente una "fórmula". Dicha ley es la que designa los "elementos reguladores" de los actos humanos, y este designar es el que permite la distinción de lo mejor y lo peor. Tal es la función de la diairesis como aquel elemento que, desde el principio, es una mezcla de teoría y práctica, es decir, productivo o demiúrgico ${ }^{127}$. Esto se hace necesario ya que lo que Platón llama "vida buena", es en referencia a la vida en tanto mezcla de inteligencia y placer ${ }^{128}$. El conocimiento preciso que da la matemática a la filosofía está en el ámbito de lo eterno, puro, verdadero y sin mezcla. Pero en lo que se refiere a la vida humana que pertenece al ámbito de las cosas que han sido, están siendo y llegarán a ser, este conocimiento puro es imposible ${ }^{129}$. La aritmética filosófica sería como el esqueleto muerto de la existencia humana, o mejor, "la vida humana es como la parte demiúrgica del conocimiento tomada en su completud, y

125. Ibíd. Pág.13.

126. Ibíd. Pág. 15.

127. Ibíd. Pág.22.

128. Platón. Filebo. Madrid. Gredos. 59d.

129. Ibid. 58e-59b. 
no por alguna razón como aritmética filosófica"130. La vida humana como mixtura poética. Ello nos lleva a pensar que es posible para lo poesía filosófica, aprehender lo eterno, en tanto la mimesis sea visión directa de las Ideas. La disputa entre filosofía y poesía, si bien no se zanja, se puede al menos vislumbrar en Platón una especie de conciliación ya que "la filosofía sin poesía, exactamente como la poesía sin filosofía, es inmoderada o inmedible"131, y esto conduce a la poesía filosófica.

En esto consistirá, entonces, la defensa del poeta: que hable con la verdad, es decir, que su poíesis se dé de cara a la Idea. De ahora en adelante el poeta no mirará otra cosa que la realidad y no el aparecer de una apariencia. Y, que, además de ser agradable, sea ante todo beneficiosa, esto es, útil y necesaria tanto para la vida política como para el individuo como tal. De no cumplir con ello no podrá ser tomada en serio y se oirá como un mero encantamiento que recordaría aquel "amor infantil”, es decir, sin razón, con el que se escuchaba a estos poetas como Homero.

Citemos el largo pasaje en el cual se les da a los poetas y a sus defensores un ultimátum para su defensa:

....No obstante, quede dicho que, si la poesía imitativa y dirigida al placer puede alegar alguna razón por la que es necesario que exista en un Estado bien gobernado, la admitiremos complacidos, conscientes como estamos de ser hechizados por ella. Pero sería sacrílego renunciar a lo que creemos verdadero. Dime, amigo mío, ¿no te dejas embrujar tú también por la poesía, sobre todo cuando la contemplas a través de Homero?

_Sí mucho.

_¿ Será justo, entonces, permitirle regresar a nuestro Estado, una vez hecha su defensa en verso lírico o en cualquier otro tipo de metro?

_De acuerdo.

_Concederemos también a sus protectores aquellos que no son poetas sino amantes de la poesía_que, en prosa, aleguen a su favor que no sólo es agradable sino también beneficiosa tanto respecto de la organización política como de la vida humana, y los escucharemos gustosamente; pues seguramente ganaríamos si se revela ser no sólo agradable sino también beneficiosa.

130. Rosen, Stanley. Op. cit. Pág. 25.

131. Ibíd. Pág. 26 
¿¿Y cómo no hemos de ganar?

_Pero si no pueden alegar nada, mi querido amigo, haremos cono los que han estado enamorados y luego consideran que ese amor no es provechoso y, aunque les duela, lo dejan; así también nosotros, llevados por el amor que esta poesía ha engendrado la educación de nuestras bellas instituciones políticas, estaremos complacidos en que se acredite con el máximo de bondad y verdad; pero, hasta tanto no sea capaz de defenderse, la oiremos repitiéndonos el mismo argumento que hemos enunciado, como un encantamiento, para precavernos de volver a caer en el amor infantil, que es el de la multitud; la oiremos, por consiguiente, con el pensamiento de que no cabe tomar en serio a la poesía de tal índole, como si fuera seria y adherida a la verdad, y de que el oyente debe estar en guardia contra ella, temiendo por su gobierno interior, y de que ha de creer lo que hemos dicho sobre la poesía ${ }^{132}$.

Con respecto a si Platón hace o no justicia a los poetas, debemos pensar que tal juicio iría en contra de la tradición homérica a la que le es imposible dar razón de sí, y no a la poesía en cuanto tal, pues en esta se daba no una ignorancia sino, al contrario, un exceso de sabiduría ya que reunía no solo la escucha del poeta, sino también la visión del vidente y el saber que resultaba de tal contemplación. Visión que concordaría más con la primera explicación de la poesía en el Ion y el Fedro, esto es, la poesía como inspiración, y que tiene, más que resonancias, afinidades esenciales con la visión obtenida en ciertos ritos mistéricos como los órficos. En todo caso, se trata como hemos mencionado y como retomaremos en el ensayo "Mimesis, Inspiración y Poesía", de una propuesta más de tipo político que propiamente estética. 


\section{Bibliografía:}

Hadot, Pierre. ¿Qué es la Filosofía Clásica? México. F.C.E. 1998.

Havelock, Eric A. Prefacio a Platón. Barcelona. Visor. 1994.

Hesíodo. Teogonía. Los Trabajos y los Días. México. Porrua. 1990.

Homero, Iliada. Madrid. Planeta-DeAgostini. 1995.

------, Odisea. Barcelona. Juventud, 1970.

Kaufmann, Walter. Tragedia y Filosofía. España. Seix Barral. 1978.

Kirk \& Raven. Los Filósofos Presocráticos. Historia Crítica con Selección de Textos. Madrid. Gredos. 1983.

Lledó Íñigo, Emilio. El concepto "poiesis" en la filosofía griega. Madrid. Bermejo. 1961.

Mejía Toro, Jorge Mario. El Teatro filosófico y la Rapsodia. Otra Interpretación del Ion Platónico. Medellín. Ed. Universidad de Antioquia. 2003.

Nussbaum, Martha. La Fragilidad del Bien. Fortuna y Ética en la Tragedia y Filosofía griega. Madrid. Visor. 1995.

Platón. Obras completas. Madrid: Gredos, 1993-1999.

Rosen, Stanley. The Quarrel between Philosophy and Poetry. Studien. In: Ancient Thought. United States. Routledge, 1988.

Vernant, Jean Pierre y Vidal-Naquet, Pierre. Mito y tragedia en la Grecia Antigua. Tomo I y II. Madrid. Taurus. 1987. 


\section{IV. \\ Mimesis y educación. \\ La imagen para la educación representada por la mimesis}

Por: Jorge Armando Ardila Robledo

Resumen: ¿Cuál es la imagen del hombre que se quiere formar con la educación en esta era de las tecnologías de la información y la comunicación? ¿Es clara esta imagen para los gobernantes, los educadores, los estudiantes? Queremos con este texto señalar la importancia de tener claro el fin de la educación, su principal objetivo, y las implicaciones que este fin tiene sobre la sociedad. Los antiguos griegos tenían claro este fin en su concepto de paideia; cada polis tenía intereses particulares con respecto a la educación de sus ciudadanos, pero, en general, esta educación estaba dirigida hacia la formación y modelación de un hombre completo y determinado de acuerdo con la imagen de la areté, pues la areté era el ideal del ethos del hombre griego, el ser virtuoso era la imagen que para la educación griega buscaba ser representada por la mimesis. Pero ahora, ¿cuál es la imagen que está buscando ser representada por la educación actual? ¿Qué imagen de educación quieren representar los estados, los gobiernos, los sistemas económicos? ¿Qué implicaciones tiene esta imagen en la formación de las personas que se "educan" actualmente? Son algunas de las preguntas que se quieren abordar de manera crítica en este texto.

El presente texto busca establecer una relación entre el concepto de mimesis y el de educación en la época de la antigua Grecia, para generar cuestionamientos entre la imagen para la educación que era representada en el período clásico griego y lo que está siendo hoy representado desde el ámbito educativo en nuestra época de la tecnología y de la información virtual. Discutiendo sobre estos aspectos podríamos abrir caminos a la pregunta: ¿De qué manera se nos da hoy la mimesis en la educación?

"Todo pueblo que alcanza un cierto grado de desarrollo se halla naturalmente inclinado a practicar la educación" ${ }^{133}$, y todos sabemos la gran importancia que tenía la educación para los antiguos griegos. Realicemos entonces una indagación en el concepto de paideia en la cultura griega para acercarnos a las imágenes que eran representadas con la educación en este tiempo. Imágenes que hicieron parte del conocimiento esencial de la educación griega y que comparadas con las posibles

133. Jaeger, Werner. Paideia: Los ideales de la cultura griega. México. Fondo de Cultura Económica. 2001. pág. 3. 
imágenes que se representan en la educación actual, parecen no guardar muchas semejanzas pese a que el origen de nuestra cultura occidental tenga sus raíces en la antigua Grecia.

El concepto de paideia abarca conjuntamente a la educación, al mismo tiempo que reúne aspectos como la misma cultura, la civilización, la literatura y la tradición; de tal forma que la palabra paideia comprende la totalidad de la obra creadora del pueblo griego. De esta forma, la educación no era concebida como un asunto aparte o aislado del todo de su cultura.

Uno de los temas que permea toda la cultura griega, quizá el más esencial, es el concepto de areté, que puede ser entendido como la "virtud" del hombre griego heroico y político; la areté se halla presente pues en todos los ámbitos de esta cultura, en la poesía de Homero y de Hesíodo, y aparece como el ideal del ethos del hombre griego; el ser virtuoso debe ser parte del carácter de este hombre. La educación desde la filosofía platónica centra su atención en el concepto de areté, las preguntas sobre si es posible enseñar a un hombre a ser virtuoso y sobre la manera en que se muestra la areté son preguntas esenciales en los diálogos de Platón.

Pero, entonces, ¿es posible enseñar la areté? Esta pregunta fundamental se halla al principio de toda ética y de toda educación. Hesíodo la suscita, apenas pronunciada la palabra areté. "Ciertamente, es el mejor de los hombres aquel que todo lo considera, y examina qué cosa será en último término lo justo. Bueno es también el que sabe seguir lo que otro rectamente le enseña. Sólo es inútil aquel que ni conoce por sí mismo ni toma en su corazón la doctrina de otro.” Estas palabras se hallan, no sin fundamento, entre la enunciación del fin -la aretéy el comienzo de los preceptos particulares que se vinculan inmediatamente a él. Perses, y quienquiera que oiga las doctrinas del poeta, debe hallarse dispuesto a dejarse guiar por él si no es capaz de conocer, en su propia intimidad, lo que le aprovecha y lo que le perjudica. ${ }^{134}$

No en vano nos dice Werner Jaeger haciendo referencia a la educación en el periodo primitivo y clásico de la cultura griega: "En el concepto de la areté se concentra el ideal educador de este periodo en su forma más pura"135. Aquí podríamos encontrar el primer indicio, o mejor, el fundamento de la imagen que era representada en la educación de la Grecia antigua. La areté como imagen era representada desde

134. Ibíd. pág. 79.

135.Ibíd. pág. 21. 
el teatro, desde la poesía, desde la filosofía, como un modelo a seguir, como una imagen del hombre griego. Así lo sustenta Jaeger en su libro Paideia: los ideales de la cultura griega:

De la educación, en este sentido, se distingue la formación del hombre, mediante la creación de un tipo ideal íntimamente coherente y claramente determinado. La educación no es posible sin que se ofrezca al espíritu una imagen del hombre tal como debe ser. En ella la utilidad es indiferente o, por lo menos, no es esencial. Lo fundamental en ella es ka入óv, es decir, la belleza, en el sentido normativo de la imagen, imagen anhelada, del ideal. ${ }^{136}$

Esta cita es importante para argumentar la idea de que existe una imagen para la educación que busca ser representada, como lo queremos ver, por la mimesis. "Aquí la educación se convierte por primera vez en formación, es decir, en modelación del hombre completo de acuerdo con un tipo fijo"137. En la época clásica en Grecia, esta imagen estaba bien definida, nos atrevemos a decir aquí que dicha imagen es la imagen del hombre griego, y esta imagen debe ser bella, debe estar dentro de los términos de la kalokagathía, de lo bello y lo bueno. La utilidad, como nos lo dice Jaeger, es indiferente o, por lo menos, no es esencial a la imagen del hombre ofrecida al espíritu a través de la educación. Nos adelantaremos a decir aquí que lo que no se quería que fuera imitado o representado en la imagen para la educación en la antigua Grecia, es precisamente lo que parece que está siendo representado en nuestra educación actual, la utilidad, "estudiar para ser útiles en algo" ahora parece ser lo fundamental; educar para la técnica parece ser la imagen que se busca sea representada para la educación en el contexto de la tecnología y la información.

Apoyándose en Platón, Jaeger argumenta que en Las Leyes ${ }^{138}$ se determina la esencia de toda verdadera educación o paideia; la educación para la areté impregna al hombre del deseo y el anhelo de convertirse en un ciudadano perfecto y le enseña a mandar y a obedecer, sobre el fundamento de la justicia.

Aquí entra otro elemento importante, y es la comunidad. Esa imagen del hombre griego no es la imagen de un hombre subjetivo, la subjetividad nace más bien con la modernidad, pero en la antigua Grecia, el hombre no podía pensarse a sí mismo sin la polis. Dice Jaeger:

136. Ibíd. pág. 19.

137. Ibíd. pág. 36.

138. Platón, Leyes, 643 E. 
La esencia de la educación consiste en la acuñación de los individuos según la forma de la comunidad. Los griegos adquirieron gradualmente conciencia clara de la significación de este proceso mediante aquella imagen del hombre y llegaron, al fin, mediante un esfuerzo continuado, a una fundamentación del problema de la educación más segura y más profunda que la de ningún pueblo de la tierra ${ }^{139}$.

Sin la polis el hombre nunca podría pensarse como un ser político, de hecho, una descomposición de la polis generaría una descomposición en la imagen del hombre y, por ende, en la imagen para la educación que va a ser representada por la mimesis. He aquí la importancia de la relación Estado - Educación. Nos dice Jaeger al respecto:

El estado-ciudad más antiguo era para sus ciudadanos la garantía

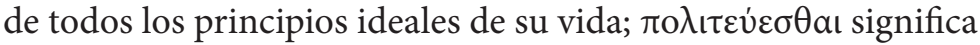
participar en la existencia común. Tiene también simplemente la significación de "vivir". Y es que ambas cosas eran uno y lo mismo. En tiempo alguno ha sido el estado, en tan alta medida, idéntico con la dignidad y el valor del hombre. Aristóteles designa al hombre como un ser político y lo distingue, así, del animal, por su ciudadanía. Esta identificación de la humanitas, del ser hombre, con el estado, sólo es comprensible en la estructura vital de la antigua cultura de la polis griega, para la cual la existencia en común es la suma de la vida más alta y adquiere incluso una calidad divina. Un cosmos legal, de acuerdo con este antiguo modelo helénico, en el cual el estado es el espíritu mismo y la cultura espiritual se refiere al estado como a su último fin, es el que bosqueja Platón en las Leyes. ${ }^{140}$

Pero hay que anotar que cada polis tenía un estado diferente, por ejemplo, en las Leyes nos dice Platón que "la Esparta del siglo IV posee, en Tirteo la más alta manifestación del espíritu del estado dórico, cuya finalidad se halla en la educación pública de los ciudadanos, es decir, en la formación para la destreza guerrera [...]. Pero esta misma rigidez muestra hasta qué punto la antigua Esparta consideró la educación musical como algo esencial para la formación del ethos humano en su totalidad. Fácil es imaginar el influjo de esta fuerza artística en una época en que pudo desarrollarse con la plenitud de su vitalidad originaria"141. Así pues, vemos cómo la imagen para

139. Jaeger, Werner. Op. Cit. p. 9.

140. Ibíd. Pp115 - 116

141. Ibíd. pp. $101-102$. 
la educación se halla en estrecha relación con la imagen que desea ser representada por el Estado.

El Estado ejercía un rol educador sobre sus ciudadanos en diferentes esferas de la cultura, como por ejemplo en los concursos gimnásticos y musicales que se celebraban en honor de los dioses. Como se sabe, Platón resaltaba la importancia de la gimnasia y de la música en la educación de los jóvenes. El orgullo por pertenecer a determinada polis era algo que se gestaba en estos concursos, de tal manera que la imagen del hombre griego guardaba una semejanza con la imagen de su propia polis. De allí la importancia de las leyes que eran consagradas en cada Estado, las cuales debían contemplar, consolidar y defender la imagen para la educación que iba a ser representada por la mimesis en cada hombre.

Tal es la significación del nuevo estado para la formación del hombre. Dice Platón, con razón, que cada forma de estado lleva consigo la formación de un determinado tipo de hombre, y lo mismo él que Aristóteles exigen de la educación del estado perfecto que imprima en todos el sello de su espíritu. "Educado en el ethos de la ley" dice la fórmula, constantemente repetida, del estado del siglo IV $^{142}$. De ella se desprende claramente la inmediata significación educadora de la erección de una norma jurídica, universalmente válida mediante la ley escrita. La ley representa el estadio más importante en el camino que conduce desde la educación griega, de acuerdo con el puro ideal aristocrático, hasta la idea del hombre formulada y defendida sistemáticamente por los filósofos. ${ }^{143}$

La imagen para la polis, la imagen para la educación, la imagen para el hombre, es uno de los temas centrales en las obras de los filósofos Platón y Aristóteles. Así, para Platón el legislador debe ser el mismo filósofo, y para Aristóteles, en su Ética, debe haber un legislador que realice el ideal del hombre proclamado desde la filosofía. Esa imagen para el hombre debía ser diseñada desde la esencia de la filosofía siendo esta la base de la educación. No es gratuito tampoco que, desde el pensamiento griego, el legislador sea colocado al lado del poeta y que, por consiguiente, las leyes estén relacionadas con las grandes obras poéticas. Así lo expresa Jaeger: "el espíritu filosófico comienza a convertirse en una fuerza educadora, pues la poesía sigue siendo como siempre la expresión auténtica de la cultura y de la educación de la 
nación"144.

Nos queda hablar sobre la relación entre el concepto de mimesis y el de educación, para ello traemos a Platón quien había derivado todas las artes de una raíz común que era el afán de imitación. Así como el pintor que puede representar un paisaje en imágenes, el poeta que puede representar en palabras un suceso heroico, el actor que puede imitar a un personaje de una obra trágica, etc. Pero no solo la mimesis permea a las artes, sino que ella abarca a todas las manifestaciones y expresiones humanas en general. En nuestro caso, la mimesis que abarca, como producción, a la educación. Pues, como hemos visto, la educación puede ser representada o ser traducida a imágenes (eídola), de manera concreta a una imagen especial: la imagen del hombre. Y así como el poeta o el pintor se hacen parecidos en su personalidad a sus propias obras, el hombre hace lo mismo de acuerdo con su educación. He aquí una particularidad de la mimesis: que aquello que imita o representa influye directamente en el carácter o el ethos del imitador.

Toda imitación es un cambio del alma; es, por tanto, el abandono pasajero de la forma anímica propia y su adaptación a la esencia de lo que se trata de representar, lo mismo si se trata de algo mejor que si es algo peor. Por eso Platón quiere que los "guardianes" no se ocupen de representaciones dramáticas más que para personificar las formas de la auténtica areté. ${ }^{145}$

Para complementar el concepto de mimesis, hablemos de otro concepto importante en la cultura Griega, el concepto de paradigma. Bien podríamos hablar de paradigmas míticos en La Iliada y La Odisea de Homero para perseguir el ethos educativo de la poesía, como por ejemplo en Aquiles, Héctor, Ulises, etc., y en la filosofía de Platón, la imagen socrática como un modelo o paradigma de lo justo.

En La República de Platón se nos presenta la construcción de un Estado ideal. Así, cuando Platón expresa que su ficción del estado o del hombre ideal es un poema mítico ${ }^{146}$, está colocando dicho estado y dicho hombre como un paradigma y a su vez reconociendo la fuerza que tienen las imágenes de la poesía para ser imitadas. Es importante la aclaración de Jaeger cuando nos dice que "el concepto Platónico del paradigma encierra, además, otro factor: el del modelo ético" ${ }^{147}$. Analiza también,

144. Ibíd. pág. 167.

145. Ibíd. pág. 616.

146. Platón. República. 501 E.

147. Jaeger, Werner, Op. Cit. p. 657. 
que en La República ${ }^{148}$ ya se expone la relación entre la virtud y el hombre que la imita, así, la justicia al lado del hombre justo, la valentía al lado del hombre valiente, etc., luego Aristóteles, en su Ética, desarrollará este método de tipificación de los conceptos éticos.

Para analizar la relación entre el concepto de mimesis y el de educación en la cultura griega, vemos entonces que aparecen varios factores directamente encadenados, como lo son las leyes y la ciudad-estado o la polis. Así, desde La República de Platón, el modelo ético debe permear el paradigma del Estado a su vez que ambos se vean reflejados en la educación y en la imagen del hombre. Allí es donde toman forma esas imágenes que tenían los griegos con respecto a la educación, imágenes de un ciudadano que no se podía pensar a sí mismo sin la polis y que guiaba sus acciones en busca de la areté, imágenes que estaban construidas a partir de la poesía, de la ética y la filosofía, y que eran las que reforzaban el ethos que le permitía al ciudadano participar activamente como "guardían" de la ciudad-estado. Este modelo de los griegos debe servirnos pues para pensar la manera en que se nos está dando hoy la mimesis en la educación, en una época donde los estados ven el poder como un fin en sí mismo y donde la tecnología y la información virtual empiezan a ocupar el puesto que en los griegos ocupaba la filosofía.

Así pues, lo que está siendo hoy representado desde el ámbito educativo en nuestra época, se vincula no solo al aspecto tecnológico, sino principalmente a la base sobre la que este se estructura, es decir, a los modelos económicos de los países, principalmente el capitalismo. El lenguaje del sistema capitalista contemporáneo se va filtrando cada vez más en el campo de la educación. Aparecen términos como evaluación por competencias, se habla de logros, estándares, desempeños, y se incorporan nuevas palabras, propias de la administración de las empresas, como lo es la palabra "calidad". El saber y el conocimiento se han puesto, en nuestra época, al servicio de la economía. Ya se habla de "Economía del conocimiento", de "Economía de la información y del aprendizaje”, cuyo fin último es generar valor y riqueza a partir del conocimiento, lo que quiere decir, emplearlo como una herramienta de producción.

Con todo esto, los establecimientos educativos, colegios y universidades, se están asemejando, cada vez más, a lo que entendemos hoy día por empresas. La reducción de la educación al mercado nos va arrastrando a pasos agigantados a una crisis educativa, la cual será difícil superar si no se vuelve a concebir la esencia de la educación desde las humanidades, desde la reivindicación de la ética, desde la formación de ciudadanos y ciudadanas del mundo con un sentido de responsabilidad

148. Platón. República. 472 B-C. 
social, como lo sugiere el profesor Guillermo Hoyos (Director del Instituto de Bioética y profesor de Filosofía en la Pontificia Universidad Javeriana (Colombia)) en su texto Educación y Ética para una ciudadanía cosmopolita:

Si se libera a la educación de la lógica del mercado para pensarla como proceso de formación de ciudadanas y ciudadanos del mundo, queda abierta al horizonte de las humanidades y de las ciencias sociales, desde el cual los máximos morales y los mínimos éticos pueden ser comprendidos como valores y normas, complementariedad que da pleno sentido a los códigos de conducta. ${ }^{149}$

Varios son pues los pensadores que han protestado frente a esta cuestión de que la educación actual está cada vez más orientada hacia los valores del mercado. Martha Nussbaum, en su libro Sin fines de lucro. Por qué la democracia necesita de las humanidades, sostiene que una educación así desplaza a una verdadera educación para la ciudadanía que forme personas críticas, capaces de tomar decisiones y de deliberar juntas sobre el bien común. Sobre este libro, comenta el profesor Guillermo Hoyos: "Nussbaum sostiene la tesis de que la decadencia de las humanidades en la educación actual puede significar un verdadero desastre para la democracia, ya que las mismas son esenciales para formar ciudadanas y ciudadanos que se reconozcan democráticamente". 150

En la tarea de educar para la ciudadanía y para la democracia, Nussbaum vuelve fundamentalmente a los antiguos griegos, retoma la pedagogía socrática y la importancia de la argumentación. Precisamente, el llamado de la mimesis en el presente texto, en su relación con la educación, está pues dirigido hacia un volver la mirada hacia los griegos, hacia un reflexionar en torno a las imágenes que los griegos tenían para su educación, prestando atención a su verdadero sentido, el cual parece estar siendo olvidado en nuestros sistemas educativos actuales.

149. Hoyos Vásquez, Guillermo, Educación y Ética para una ciudadanía cosmopolita, Revista Iberoamericana de Educación No. 55 (2011), pp. 191-203.

150. Ibíd. pág. 197. 


\section{Bibliografía}

Benéitez Prudencio, José Javier, Martha Nussbaum. Peter Euben y la educación socrática para la ciudadanía. Revista de Educación. 350. Septiembre-diciembre 2009. pp. 401-422. Madrid. España. Ministerio de Educación, Cultura y Deporte. Edición digital en: www.revistaeducacion.educacion.es

Gutiérrez, Alba Cecilia. Belleza y mimesis en la estética platónica. Artes La Revista, Volumen 1 No. 2 Facultad de Artes. Universidad de Antioquia. Medellín. Colombia. Julio - Diciembre 2001.

Jaeger, Werner, Paideia: Los ideales de la cultura griega. México. Fondo de Cultura Económica. 2001.

Hoyos Vásquez, Guillermo. Educación y Ética para una ciudadanía cosmopolita. Revista Iberoamericana de Educación No. 55 (2011). pp. 191-203. Publicación editada por la OEI.

Luckáks, Georg, Estética 1. La peculiaridad de lo estético. Traducción de Manuel Sacristán. Barcelona Grijalbo. 1982.

Nussbaum, Martha C. Sin fines de lucro. Bogotá. Panamericana. 2010. 199pp.

Platón. Diálogos I (Apología de Sócrates, Critón, Eutifrón, Hipias Menor, Hipias Mayor, Ion, Lisis, Cármides, Laques, Protágoras). Madrid. Ed. Gredos.1997.

Platón. Diálogos II (Gorgias, Menéxeno, Eutidemo, Menón, Crátilo). Madrid. Gredos. 1999. 


\section{$V$. \\ Mimesis, inspiración y política en Platón}

Por: Luis Guillermo Quijano Restrepo

Resumen:La propuesta de Platón de encaminar la vida política de los ciudadanos a través de la poesía y la mimesis no solo no es extraña, sino que es, por el contrario, esencial para su realización. Y no pensemos que se trata meramente de un aspecto metafísico (tan temido hoy por los ciudadanos del siglo XXI), es ante todo una forma de vivir, se trata de la imitación de la vida más bella y mejor, la verdadera tragedia. Por ello mismo, se procede a revisar el elemento de la inspiración, presente en el Ion, el Fedro, para luego considerar el aspecto de la mimesis en República X, con el fin de mostrar la síntesis que se realiza de ambas en las Leyes con el Poeta legislador.

\section{Introducción.}

El estudio de la mimesis en Platón, ha sido por lo regular, orientada hacia la poesía, de tal manera que en esta se retoma de manera incesante su aspecto negativo, en tanto aquella, la mimesis, sería inconveniente para el Estado. Esto es un tanto inexacto en la medida en que en la República, efectivamente, se hace hincapié en este aspecto, debido a que allí Platón quiere partir de la mimesis negativa (o mala para algunos), que consiste tanto en imitar mal, por ejemplo a los dioses, adjudicándoles aspectos erróneos a su naturaleza, o bien en pretender imitar de manera exacta lo que no se puede, generando la apariencia de lo real. Ambas formas son descartadas por Platón, de tal manera que aquellos imitadores que persistan en este tipo de imitaciones serán expulsados de la República, se les despedirá con honores, pero a cambio, sufrirán el destierro. Sin embargo, sus guardianes serán formados por aquellas "mentiras útiles" que despertarán en ellos los más altos valores, es decir, la mimesis es vehículo para conducir al guardián en el camino de los principios que regirán su conducta, su ethos. Aquí se da paso a la mimesis positiva (o buena para otros). Esta formación en la poesía que aplica la imitación positiva será en todo caso provisional y luego los superará por otros discursos más acordes con el desarrollo de su alma, los filosóficos.

Es en el Fedro donde este discurso, más amoroso, le permite al amado recuperar sus alas al rememorar en el cuerpo de su amante, su antigua 
condición divina. Aquí el discurso es ante todo inspirado, es decir, el dios toma posesión del amante (Sócrates) que le inspira a recitar a su amado (Fedro) una hermosa palinodia en honor al Amor. Discurso que no deja de producir una extraña transformación que hace a quien lo recita pasar de ser el amante (activo) a ser el amado (pasivo). Previo al Fedro, hay un diálogo menor de juventud, el Ion, en el que se detalla el asunto mismo de la inspiración en la poesía, más específicamente en la rapsodia. Allí, el rapsodo Ion asegura que el éxito de su oficio radica en el arte o techne y no en otra causa distinta; Sócrates es contundente y le conmina a aceptar que su buena disposición para con Homero, su poeta preferido, es causa de la inspiración (y no de la téchne), que la Musa en primera instancia le comunica al poeta y luego al intérprete y al espectador por una suerte de magnetismo que se visualiza a través del símil de la piedra magnética o imantada. La relación de la poesía con lo divino se hace patente en estos dos diálogos en los que se desarrolla la idea de una poesía más positiva y divina, la poesía filosófica.

En los anteriores diálogos, sin embargo, no se evidencia ninguna relación entre mimesis e inspiración, al menos no es explícita. Un poco más es la relación con el asunto ético y político: en la formación del guardián (República), del iniciado en el amor (Fedro y Banquete), la poesía cumple un papel netamente mediador; la poesía es tanto veneno como antídoto para la formación del ciudadano. Por eso se hace necesaria una figura que la administre con logos, un hombre que haya sido iniciado tanto en los misterios del Amor, como en los de Dioniso: un poeta legislador. Es en las Leyes donde esta figura tiene lugar, especialmente en el libro VII, donde se hace explícita esta relación entre la mimesis y el enthousiasmos. Esta relación va a ser fundamental para entender aquella poesía apropiada para el Estado, tanto para formar ciudadanos como para regir la ciudad misma.

Este breve ensayo tiene como fin, el estudio de esta relación entre mimesis y política, más específicamente, mostrar la política como mimesis. En efecto, en Platón se puede rastrear este asunto en la medida en que partamos de la idea de mimesis como el elemento que le permite al hombre ponerse en el lugar de, es decir, salir de sí mismo, a través de un ser externo a él mismo (en este caso el divino) y reproducirlo para apropiárselo o alcanzarlo. Casi se podría decir que la mimesis más que una mera representación, este sería su resultado, es ante todo un modo de ser impropio en un principio para devenir deseable y alcanzable. La poesía debe ser para Platón este medio por medio del cual los hombres podrían alcanzar las virtudes que le permitirán el gobierno de sí y de los otros. 


\section{Mimesis en República $X$}

En las obras de Homero, los dioses del Olimpo se reúnen en asambleas lideradas por Zeus. Así mismo los prohombres se reúnen alrededor de sus caudillos y deliberan sobre las decisiones que afectarán a toda su comunidad. Entre ellos se esconden los dioses que les inspiran sus argumentos. Esta es la imagen que los espectadores reciben de los rapsodas. De esta manera Homero se convierte en el educador por excelencia de la Hélade. Los hombres imitan a los prohombres, como los prohombres imitan a los dioses. ¿Por qué entonces, Platón critica a Homero? ¿Cuál es el modelo a seguir para la formación del ciudadano? El asunto no hay que buscarlo en las referencias sobre los dioses, tampoco en las relaciones de los hombres con los dioses, sino en la forma contradictoria en que el poeta usa de los símiles, de las imágenes de los dioses. Si se parte de la perfección divina, si en los dioses no es posible su degradación física, tampoco sería posible su degradación moral, la naturaleza divina no es contradictoria. Los dioses no mueren como los hombres, tampoco envejecen, no sería por ello razonable otorgarles comportamientos inapropiados a su naturaleza. Es de esta manera como Platón en los libros II a IV de la República, comienza su crítica a Homero y Hesíodo. En ellos Platón cita, por boca de Sócrates sendos pasajes en los que se hacen explícitas tales contradicciones. La imagen que utilizan los poetas para representar a sus dioses es completamente inadecuada y desvirtúa la naturaleza divina. Pero lo más grave de todo ello es que quienes escuchan tales narraciones, podrán asumir también estos comportamientos, con lo cual se dará lugar a la hybris (desmesura) en la ciudad. Este tipo de imágenes que son el resultado de esta contradicción serán censurados y sus artífices desterrados. En esto consiste la primera forma negativa de la mimesis. En ella la imagen no corresponde con la realidad a la que remite (la divinidad). En ella se da el engaño, acompañada de desmesura.

La segunda forma negativa de la mimesis tiene que ver con la anterior, en el sentido en que también remite al engaño, pero a diferencia de la anterior, quiere hacer parecer como si ella misma fuera la realidad. En el libro X aparece al inicio un símil con el que Sócrates le quiere explicar a Glaucón como se produce una apariencia de realidad a partir del espejo:

...Es hecho por artesanos rápidamente y en todas partes; inclusive con el máximo de rapidez, si quieres tomar un espejo y hacerlo girar hacia todos lados: pronto harás el sol y lo que hay en el cielo, pronto la tierra, pronto a ti mismo y a todos los animales, plantas y artefactos, y todas las cosas que acabo de hablar. ${ }^{151}$

151 Platón. República. Madrid. Gredos. 1999. 596d. 
Interesante imagen que podemos asociar al espejo con el cual el infante Dioniso juega con él, antes que los Titanes lo maten y en cuyo momento aquel, al verse en él, ve reflejado el mundo. Así también Sócrates en su explicación, va con el espejo que refleja cada cosa y muestra la ilusión que genera el creer que hace lo que refleja. Así el pintor que al retratar con exactitud a un carpintero, al mostrarlo de lejos a los niños y hombres insensatos, los engañará al hacerles creer que es de verdad. Parece un tanto exagerado este símil, en realidad está cargado de toda la ironía socrática en la que consigue, por medio de la radicalización de la imagen, develar su aspecto negativo y vano. Hacer un calco de lo real no solo es empobrecedor desde el punto de vista creativo (tal vez esto ni siquiera lo hubiese considerado un griego), sino sobretodo es una ilusión, un engaño al pretender suplantar el calco por lo real. En este sentido el imitador es todo un hechicero, con lo cual urge encontrar un remedio que neutralice su efecto.

Pero podríamos preguntarnos ¿no es acaso este simulacro algo real también?

En la concepción platónica esta pregunta se responde negativamente. En efecto, la producción artística está alejada de lo Real en tres niveles: el primero, recordemos, está en relación con las formas originales (eidos); luego está el nivel de lo natural (physis); luego el nivel de los artesanos que fabrican sus artefactos a partir de las formas originales; finalmente el pintor o mimetés quien producirá una imagen (eidolon) de la imagen (eidos) que produce el artesano (demiourgos). ¿Qué quiere decir esto? Que lo Real (que viene de rey, realeza, principio) debe ser puro eidos, es decir, pura forma. La mimesis por ser imagen de la imagen, no cabe en esta categoría. Es representación (volver a presentar lo que de hecho ya se ha presentado), que implica de una parte una subordinación de lo representado a lo presente, de la imagen a lo real, pero también una distinción con ello mismo, una suerte de nuevo estatuto, de una nueva forma de presentarse lo real, otra forma de ser. La mimesis como tal tiene un resultado, la imagen de la imagen, su representación. Pero circunscribir la mimesis a mera imagen es mostrar su aspecto inerte, su lado muerto. La imagen que pretenda pasar por real, simplemente debe ser censurada y rechazada porque crea una ilusión y en este sentido, engaña no solo la percepción, sino al alma, la confunde y la obnubila y le impide elevarse hacia las formas. El mimetés, autor de esta imagen, no estaría exento tampoco de rechazo, incurriendo por ello en falta moral por propiciar el engaño en el alma.

De la misma manera como ocurre con la pintura, así mismo ocurre con las artes poéticas, incluidas la epopeya y la tragedia que imitan las acciones esforzadas de los hombres y los héroes. En este ámbito ¿qué es lo que Sócrates recrimina a los trágicos y poetas en general? Que exalten la parte baja del alma, a través de la imitación de los caracteres débiles, femeniles, o por el contrario desmesurados y violentos. Con ello el poeta promueve la incontinencia, la desmesura y los estados anímicos que 
ponen en juego la ley misma en la ciudad. En última instancia promueven el estado anómico y dan lugar a que el azar reine en el gobierno menor (del alma) y del mayor (el del Estado). Por este motivo es que estos poetas son expulsados de la ciudad, sin vejaciones, con honores pero desterrados si no están dispuestos a atenerse a las normas que el logistikon (raciocinio) impone. Este lleva a que la parte razonable del alma se imponga sobre la animal o sensitiva y conduzca a esta última en función de aquella. El poeta tendrá que orientar su producción a exaltar aquellos valores como la piedad, el valor, la continencia, etc., que le permitan al hombre tanto avanzar en su proceso dialéctico de alcanzar la idea del Bien como de convivir y participar como ciudadano en los asuntos políticos que le conciernen al Estado como tal.

Como puede verse, hay ya en este libro una normatividad para el hacer poético que no puede confundirse con una "técnica" sin más. Si bien aquí parece primar lo negativo, lo normativo, no por ello la techne (técnica, arte) define aquí a la mimesis. Mimesis no es técnica, sigue siendo imagen pero acorde con la naturaleza divina y humana. Esta forma de mimesis, regida por el logistikon, va a ser asumida por el Estado y será incluida en la formación de los guardianes de la ciudad. Esta mimesis es, entonces, paideia, la cual, a partir de la niñez, será la que oriente los procesos de enseñanza y aprendizaje de estos elegidos que gobernarán el Estado. En este caso el veneno se convierte en remedio y antídoto contra el veneno de los imitadores hechiceros, mimesis como pharmakon. En esto consiste el aspecto positivo de la mimesis: que es el antídoto contra el mal que puede causar la mimesis negativa. Platón mismo incluye en sus textos este tipo de mimesis, en la forma de mitos. Incluso en este mismo libro $\mathrm{X}$ encontramos el famoso mito de $E r$ en el que se describe cómo este guerrero explica su tránsito al más allá. Lo que diferencia este tipo de imágenes de las empleadas por los poetas griegos es que incorporan un logos que explica de manera narrativa, una realidad que por ser tan abstracta debe ser "ilustrada" por medio de imágenes míticas y familiares para los griegos mismos. Explicar, por ejemplo la inmortalidad del alma, la idea del bien, el conocimiento, etc., requiere de algunos artificios narrativos que Platón toma prestado de los misterios órficos y eleusinos. La inspiración sería el garante de la realidad del relato, del mito. En esto consisten las llamadas "mentiras útiles" 152 que no son más que mitos reservados a los hombres que gobiernan el Estado, elaborados a partir del logistikon para beneficio del mismo y que actúan como remedio (pharmakon) contra el hechizo de los imitadores.

Decíamos que la mimesis en Platón no puede ser tampoco techne, es decir, no puede ser reducida a una mera normatividad que regula una producción poiética determinada. La mimesis es un acto que está relacionado con lo divino. En efecto, la mimesis tiene sus orígenes religiosos en los que los seguidores de un dios, 
imitan sus gestos, movimientos y actos para ser poseídos por él. Más bien: en la posesión que los iniciados sufren por el dios, asumen sus gestos y actos propios de la divinidad. Con ello queremos decir que la práctica mimética presupone un influjo externo y ajeno a aquel que lo padece. La imitación no es un acto mecánico y calculado, es un don divino que le viene al imitador o mimetés a pesar suyo. Sin embargo mimesis y enthousiasmos (inspiración) no son lo mismo. Esto se constata en la medida en que hay una mimesis que se puede realizar por techne, tanto como hay poesía no inspirada. Podríamos aventurar la hipótesis que para Platón, esta mimesis con techne es precisamente la negativa, en tanto la mimesis positiva es la inspirada. ¿Quiso Platón sugerir acaso que Homero, Hesíodo o los grandes trágicos eran mimetai por la techne? Esto parece muy improbable, sin embargo puede al menos pensarse que así como el peor de los poetas mencionado en el Ion, Tínico, tuvo la gracia de hacer los versos más hermosos, así también podemos pensar que el más inspirado de los poetas, Homero, no siempre lo estuvo ${ }^{153}$. Este aspecto de la mimesis y su relación con la inspiración divina, se desarrollará a continuación.

\section{Mimesis e Inspiración en Ion y Fedro}

En primera instancia, la inspiración pareciese circunscribirse a lo artístico y/o religioso. Pero en el aspecto político, ¿es pertinente pensar que lo rige también el enthousiasmos? Es una pregunta que nos la hacemos nosotros ciudadanos del siglo XXI, época en la que todas nuestras actividades y oficios están divorciadas del elemento divino. No así para el pensar del griego del siglo V. Por eso no es de extrañar que en el Menón, la política tenga este matiz divino. Así al menos lo expresa al final del diálogo cuando Sócrates le dice a su interlocutor que lo que dirige a los políticos no es la ciencia (episteme) sino la conjetura verdadera y así no se distinguen de los profetas y adivinos:

“...y no tendremos menos razón para conceder este título a los políticos, que debemos mirar como hombres llenos de entusiasmo, inspirados y animados por la divinidad"154

Si bien en los diálogos que vamos a considerar (solo en lo que tiene que ver con el asunto de la inspiración), cuales son el Ion y el Fedro, no se hace referencia a la

153. "Sólo podemos concluir que es al artista a quien debemos culpar, por confundir la inspiración de la Musa. Esto significa que su estado de posesión no es absoluto: la Musa no le dirige completamente su habla y él no pierde por completo su carácter humano": Verdenius, W.J. Mimesis: La Doctrina Platónica sobre la Imitación Artística y su Significado para Nosotros. En: Estudios de Filosofía. Universidad de Antioquia. No. 14 Agosto de 1996. 11-40.

154. Platón. Menon. México. Porrúa, 1998. 99d. 
mimesis, no por ello debemos inducir que no se da. Por el contrario, su no mención implica de por sí una inmanencia. De hecho, en el Ion nunca se menciona, sin embargo, se recurre siempre a Homero y los poetas en general para ilustrar cómo opera en ellos la divinidad. Es importante aclarar que este diálogo se centra en la figura de un rapsodo que no es de por sí poeta, sino interprete de las epopeyas de los poetas Homero y Hesíodo (aunque en el caso de Ion, solo de Homero). Este rapsodo está convencido que su arte le viene por techne, esto es, por pura virtud en su arte. ¿Qué implica esto y por qué Sócrates se empecina en persuadirlo que es por puro entusiasmo que recibe su arte?

El transfondo de todo esto es un asunto político. Se trata de una batalla a muerte que libra Sócrates contra sus archienemigos los sofistas. Resulta que ellos van de ciudad en ciudad seduciendo a los jóvenes para que se hagan sus discípulos y a cambio de sabiduría éstos les pagan con dinero y con fama. En efecto, en el diálogo antes citado, Menón, se hace referencia al problema de si es posible o no enseñar la virtud como lo aseguran los sofistas. Si la virtud puede ser transmitida, entonces los mejores gobernantes tendrían la oportunidad, por vía directa y no por intermediarios, de enseñarles a sus herederos los misterios de la política. Sin embargo ello no ha sido así y por el contrario, se puede constatar que los hijos de estos hombres virtuosos siguen caminos contrarios a los de sus padres. Los sofistas, por el contrario, persuaden a sus seguidores que la virtud, así como cualquier oficio, puede ser enseñada. De hecho, el rapsodo Ion, interpreta a Homero bajo la influencia de los sofistas, incluyendo en sus actos rapsódicos la dramaturgia, el adornar y explicar los textos de los poetas: “...A mí, al menos, ha sido esto lo más trabajoso de mi arte, por eso creo que de todos los hombres soy quien dice las cosas más hermosas sobre Homero"155, replica Ion cuando Sócrates le insinúa la importancia de comprender qué dice el poeta para un intérprete como él. Ion ha caído en la trampa de los sofistas al pensar que su arte radica en decir las más y bellas cosas sobre Homero a partir del arte retórico que ellos utilizan en sus discursos. Decíamos que se trata de un problema político el diálogo que traba Ion con Sócrates, en la medida en que aquel le da a la conversación un giro hacia este ámbito cuando Sócrates queriendo indagar sobre el objeto de su arte y sus temas, Ion le responde yendo de aquí para allá y diciendo que su arte en primer lugar trata sobre todo lo divino y lo humano; luego de que su arte trata sobre las cosas propias que dicen los hombres y las mujeres, los libres y los esclavos; también de que su arte es el arte del auriga, y de cuantos oficios se mencionan en las obras de Homero; hasta decir que su arte es el arte del general y sus estrategias militares porque sabría lo que uno de estos tendría que decir en una guerra. Con lo cual Sócrates le replica que siendo así ¿por qué él habría escogido mejor el oficio

155. Platón. Ion. Madrid. Gredos. 530d. 
de rapsodo que el de general, pues este último tendría más honor y gloria que el primero? ${ }^{156}$ Ion le responde que él, por ser extranjero, no podría ocupar tales cargos ya que los atenienses se bastan a sí mismos (Ion, 540d-542a). Pareciese ser que Ion no está dispuesto a perder el "dominio" que le confiere su arte sobre los demás. De hecho la insistencia de Sócrates consiste en hacerle ver a Ion que, quien está inspirado, no tiene dominio ni siquiera de sí mismo porque es poseído y dirigido por el dios y por ello no puede dar cuenta ni de sí mismo ni de lo que recita. En la posesión del dios, el hombre pierde su inteligencia, está fuera de sí y ya no tiene dominio sobre sí mismo. Así tampoco en lo que se refiere a los espectadores, pues el entusiasmo que generaría en ellos no es fruto de su esfuerzo sino de la fuerza del dios que, a través de la Musa, le comunica al poeta su contenido y su forma y por una suerte de magnetismo se transmite al intérprete y al espectador, como la piedra imantada o magnética que atrae hacia sí los anillos. El intérprete entonces es solo un mediador de tal fuerza y por el contrario es el dios quien actúa en é ${ }^{157}$. Así pues, Ion no domina nada, ni siquiera al público que tanto necesita. Lo político no se define por el dominio que se tenga sobre los otros, lo político tiene un remanente poiético.

El giro inesperado que toma el diálogo al final no es azaroso, sino que creemos está muy bien dirigido, en la medida en que Ion, a pesar de su tozudez, intuye la cercanía entre uno y otro ámbito. Esto por supuesto es una suposición que hacemos a partir de nuestra hipótesis. La diferencia entre uno y otro terreno estará dado por el dios y la manía que de él se derive, tal como en el Fedro se explica.

En lo que respecta al Fedro, solo tomaremos algunas características que en él se refieren a la inspiración. En primer lugar decir que hay varias clases de inspiración o de locura (manía); la primera que tiene que ver con la mantikéo la locura adivinatoria, que la genera Apolo; la segunda la de los delirantes que por los ritos se purifican, la manía mística que genera Dioniso; la tercera la de las Musas que infunden la poesía y los cantos, la manía poética ${ }^{158}$. Más adelante hablará de la cuarta forma de locura,

\footnotetext{
156. De manera semejante, Sócrates en República, 599c-d, le reprocha a Homero el que no haya podido con sus imitaciones lograr que algún Estado pudiese ser gobernado gracias a él: "Pero en cuanto a los asuntos más bellos e importantes de los que Homero se propone hablar, lo relativo a la guerra y al oficio del general, al gobierno de los Estados y a la educación del hombre, tal vez sea justo preguntarle inquisitivamente: “(...)¿Cuál Estado fue mejor gobernado gracias a ti, como Lacedemonia gracias a Licurgo, y, gracias a muchos otros, numerosos Estados grandes y pequeños? ¿Qué Estado te atribuye ser buen legislador en su beneficio, como lo atribuye Italia y Sicilia a Carondas y nosotros a Solón? ¿Y a ti cuál Estado? ¿Puedes mencionar uno?”. Esta relación del poeta con la ley y la política será de nuevo presentada en Fedro, con la figura de Pericles.

157. De hecho, para Verdenius, W.J. Op. Cit. pág.29, "La imitación artística de Platón se basa en la concepción del arte como una interpretación de la realidad y que este principio es todavía base sólida para nuestra teoría del arte. Esto no es un descubrimiento nuevo, porque el carácter interpretativo del arte parece volverse cada día más y más reconocido".
}

158. Platón. Fedro. Madrid. Gredos. 244d-245a. 
la erótica ${ }^{159}$ que es la que implanta Eros. La importancia de esta categorización de las distintas formas de inspiración radica en vislumbrar a qué tipo de inspiración corresponde la política, si es que se puede derivar de alguna de ellas.

Podemos partir de una pista que el mismo texto nos ofrece, luego de la palinodia que hiciera Sócrates al Amor:

¿Y qué? Cuando un orador o un rey, habiendo conseguido el poder de un Licurgo o de un Solon o de un Darío, se hace inmortal logógrafo en la ciudad, ¿acaso no se piensa a sí mismo como semejante a los dioses, aunque aún viva, y los que vengan detrás de él no reconocerán lo mismo, al mirar sus palabras escritas? 160

Lisias, autor del primer texto sobre el Amor en este diálogo, se presenta en este como un logógrafo reconocido por su pericia retórica. Precisamente es este arte retórico el que le permite a Sócrates responderle con otro texto a su adversario sofista, en el cual aquel tiene que cubrirse por vergüenza del propio escrito. En él muestra lo inapropiado y poco coherente que se puede llegar a ser siguiendo simplemente las normas retóricas de la persuasión, basadas más en lo verosímil que en la verdad misma. De otra parte, pensarse a sí mismo "como semejante a los dioses" quiere decir realizar una mimesis, en este caso escritural, que sea acorde a la divinidad y como tal ser reconocida por los otros. Sin embargo, esta mimesis no puede realizarse sin más y precisa de la fuerza divina. No en vano Sócrates recurre al mito de las cigarras $^{161}$ para explicar que esta fuerza proviene de las Musas que en el caso de los discursos corresponde a Calíope, Musa de la elocuencia, y Urania, musa de la filosofía. Lo que en este breve pasaje se quiere mostrar es la cercanía del discurso político con el poético. Ambos regidos por las Musas, por consiguiente, ambos deben ser semejantes a la naturaleza divina. La verdad se salvaguarda en este dominio y el discurso será bello y justo, en cambio, el discurso basado en la apariencia (mostrar lo verosímil como lo real), que ofrece al que "ignora la verdad y va a la caza de opiniones, es ridículo y burdo" ${ }^{162}$. No es el arte de la retórica la que invalida Sócrates sino a aquellos que como los sofistas anteponen la técnica a la verdad. La verdad, que se alcanza a partir de la dialéctica, debe preceder la técnica retórica, es más aquella la determina (es el mismo presupuesto del diálogo "El Político"). En efecto,

159. Ibid, 249d.

160. Ibid, 258c.

161. Ibid, 259a.

162. Ibid, 262a. 
quien pretenda recurrir al arte de las palabras sin antes recurrir a la dialéctica que le permite enumerar las distintas naturalezas de sus oyentes, de distinguir las cosas según su especie, y de abrazarlas en una sola idea,

Jamás será técnico de las palabras (...) Todo esto, por cierto, no se adquiere sin mucho trabajo que el hombre sensato no debe emplear en hablar y tratar con los hombres, sino, más bien, en ser capaz de decir lo que es grato a los dioses y de hacer, también, todo lo que les agrade en la medida de sus fuerzas ${ }^{163}$.

El ejemplo que da Sócrates del mejor retórico, el gran estadista Pericles, está basado en el conocimiento que este tenía de la naturaleza humana gracias a su cercanía con Anaxágoras (quien se conoce como un naturalista que enfocó sus estudios hacia el nous, la mente), quien le propició las herramientas que necesitaba para este arte. De nuevo aparece la relación política y mimesis, aunque esta no se encuentra de manera explícita en el texto. Son varias las referencias en este texto a los estadistas y legisladores que se sirvieron del discurso para llegar a sus oyentes. Todo discurso sea oral o escrito, se compara con un cuerpo viviente, que no solo tiene partes que lo conforman, sino, sobre todo que tiene vida, es un organismo. De hecho, podemos pensar, que este discurso es mimesis de ese otro cuerpo que se rememora en los cortejos de los dioses que otrora el alma había seguido. El mito de Theuth que aparece al final del Fedro, da cuenta de este tipo de escritura que es la que le conviene al alma. Este mito aparece en el contexto también de un reino, Egipto, y de un rey, Thamus, al cual visita el dios Theuth ofreciéndole el conocimiento de la escritura que aparece como fármaco de la memoria y la sabiduría. A lo cual le responde el rey que no es fármaco sino un simple recordatorio, que dará la apariencia del conocimiento pero no el verdadero ${ }^{164}$. Esta escritura que se siembra en el agua negra por medio del cálamo, es ese tipo de escritura silenciosa que no puede defenderse por sí misma y que es pura apariencia de sabiduría. Al contrario, hay otro tipo de escritura, que es la verdadera, que se siembra en el alma de los jóvenes, discursos que son capaces de defenderse a sí mismos, que no son estériles y cuya semilla dan la felicidad al hombre que en el se implanta. Esta escritura es la que le permite al hombre recordar su antigua condición divina, la que, como el amado, le hace nacer sus alas.

Si bien es claro que en el Fedro se privilegia esta escritura viva y verdadera, no quiere decir sin más que se desconozca aquella otra que es inválida y aparente; por el contrario, en este diálogo se le ha dado un espacio en la medida en que allí logra desvelarse y denunciarse la ausencia de claridad y unidad que en ellas impera;

163. Ibid, $273 \mathrm{e}$.

164. Ibid, $274 \mathrm{~d}$. 
también es importante el estatuto de “juego" que se le confiere a este discurso escrito y su carácter accidental o fútil:

"Pero el que sabe que en el discurso escrito sobre cualquier tema hay, necesariamente, un mucho de juego, y que nunca discurso alguno, medio o sin medir, merecería demasiado el empeño de haberse escrito" 165 ...

En Leyes, por su parte, precisamente esta condición de “juego" que rige este tipo de producción, será considerada con más rigor y atención, para la formación de los guardianes.

\section{Mimesis en Leyes II y VII}

Como lo indica Platón en "El Político", el verdadero político no se define por hacer leyes o mandar, sino por tener un conocimiento o ciencia basada en la dialéctica, que es el gobierno perfecto. El político debe ser en pocas palabras un filósofo. En Leyes, sobre todo en el libro II y VII, coinciden con esta idea, en tanto, la figura del legislador es la de un hombre versado en la dialéctica pero también guiado por aquellos tres coros que acompañan la formación del hombre: el de las Musas, el de Apolo y el de Dioniso. Al inicio de las Leyes se parte del presupuesto de que quien hace las leyes es el dios mismo (en el caso de los atenienses corresponde a Zeus). Esto implica que el legislador, que no es un dios sino un hombre, debe hacer las leyes de acuerdo a la divinidad, esto es, debe ser un mimetés de la justicia divina. Sin embargo, para que se de dicha semejanza, el legislador (tanto como cualquier hombre libre) debe pasar por un proceso de formación desde el vientre de su madre, tanto en su cuerpo (con la gimnasia) como en su alma (a través de los dones de las Musas y Apolo: la música y el canto). En todo este proceso se ejercita la mimesis, bien sea en la danza y la lucha _en las que se realizan imitaciones adecuadas y convenientes a los movimientos de súplicas a los dioses e hijos de los dioses; bien en la música y el canto, imitando las maneras del ser, de los caracteres buenos y malos. Estas imitaciones se realizan como "juegos", en la medida en que estos, por una parte son "necesarios" para los párvulos entre 3 y 6 años y recomendable para los hombres libres ${ }^{166}$; por otra y la más importante para este discurso, es que los juegos "tienen el poder para que las leyes promulgadas sean estables o no"167. Por eso es importante vigilar en la formación de los ciudadanos que estas actividades miméticas no tengan cambios, porque ello sería nefasto para la ciudad misma. El cambio en los juegos

165. Ibid, 277e.

166. Platón. Leyes. Madrid. Gredos. 794a.

167. Ibid, 797b. 
resulta "peligroso" para cualquier ciudad, debido a que cualquier innovación en ellos implica formar a hombres diferentes a los niños anteriores, "buscarán otra vida y, al buscarla, desearán otras costumbres y leyes, y después de esto, ninguno de ellos temerá que pueda llegar ese mal extremo para las ciudades que acabamos de mencionar"168. La mimesis como juego es un asunto serio y por lo tanto el hombre se debe ejercitar en él desde su más tierna edad, incluso hasta llegar a su edad madura donde se hará seguidor de Dioniso, hasta los 60 años. En este proceso se pasa por tres niveles que Platón representa en coros: el de las Musas que corresponde a coros infantiles que cantarán en público y con toda seriedad todo lo relativo a las bellas y buenas cosas: darán a conocer la índole del original; el segundo coro es el que corresponde a Apolo integrado por los jóvenes en el cual invocan a este dios como testigo de la verdad: cuidarán por la rectitud relativa de la copia; finalmente el coro de Dioniso integrado por sexagenarios que narran historias inspiradas sobre estos asuntos morales: velarán por la bondad de cada una de esas imágenes en palabras, melodías y ritmos ${ }^{169}$.

Es en este nivel, el de los cantores sexagenarios de Dioniso, en el que se llega a conocer si la imitación es buena o no, en resumen, si es adecuada y acorde con la divinidad ${ }^{170}$. Estos mismos coristas son los que le hacen saber a los trágicos que ellos también lo son "de la tragedia más bella y mejor que sea posible". Con este pasaje y el siguiente, tocamos precisamente el punto neurálgico de nuestra reflexión en el que se da explícitamente la relación poesía y política. En este sentido no coincidimos con Alexander Nehamas ${ }^{171}$ cuando afirma que en República X, Platón no expulsa los artistas sino únicamente a la poesía y no precisamente por ser mimesis. Platón si bien habla del destierro de la poesía ${ }^{172}$, también habla del destierro de los poetas imitativos ${ }^{173}$, cuando dice que "no lo admitiremos (al poeta imitativo) en un Estado

168. Ibid, $798 \mathrm{c}$.

169. Ibid, 664c y 669b. Como se puede notar, Platón, para proponer una nueva poesía, empieza por reescribir los dioses.

170. Con respecto a la reivindicación de la mimesis en las Leyes, hay que aclarar que, según Rosen, Stanley. The Quarrel between Philosophy and Poetry. Studien. In: Ancient Thought. United States. Routledge. 1988. pp 9-13, existen dos tipos de mimesis: la perfecta y la imperfecta (de la misma manera hay imágenes correctas _que no se distinguen de las Ideas como tal_e imágenes incorrectas que son de cualquier otra cosa). Se entiende que la primera corresponde a la mimesis por inspiración y la segunda a la mimesis por téchne. Esta última se rechazará, mientras que la primera se hará pública y por medio de ella se encauzarán a los jóvenes hacia la virtud.

171. Nehamas, Alexander. “Acerca de la Imitación y la Poesía en el Libro X de la República de Platón”. En: Estética: miradas Contemporáneas. Compilador. Carlos Eduardo Sanabria B. Bogotá. Jorge Tadeo Lozano. 2004. pp.21-54.

172. Platón. República. Op. Cit. 607c.

173. Ibid, 605b. 
que vaya a ser bien legislado, porque despierta a dicha parte del alma (la parte inferior), la alimenta y la fortalece, mientras echa a perder a la parte racional". Esto mismo se verifica en Leyes ${ }^{174}$ cuando los coristas le dicen a los "Excelsos extranjeros":

...hijos descendientes de las débiles Musas, mostrad primero a los magistrados vuestras canciones que nosotros las compararemos con las nuestras y, en caso de que sea evidente que dicen lo mismo o mejor lo que nosotros decimos, os permitiremos hacer una representación, pero si no, amigos, nunca podríamos dejaros. ${ }^{175}$

Nótese que los “excelsos extranjeros” de que se habla son los trágicos que ya no son de este Estado, los poetas han sido expulsados. Llama la atención de la referencia a las “débiles musas", pues cabría preguntarse si es que ya se había mencionado la diferencia entre musas débiles y musas fuertes. Al menos no, explícitamente en el texto; pensamos que se puede tratar de una referencia irónica a la mimesis que exalta la parte débil del alma (como lo expone en República $X$, donde también se menciona la "Musa Dulzona" de la tragedia), o menos probable a una poesía que siguió de manera débil la instrucción de la Musa. En todo caso, en este pasaje se retoma la temática planteada en República, donde los poetas imitadores, por exaltar la parte inferior del alma, son expulsados de la misma con su poesía. De nuevo el problema radica aquí en que los trágicos, al enfatizar sobre estos caracteres débiles y provocar el deseo de imitarlos, falsean e imitan mal la verdadera naturaleza, la divina.

Ahora bien, si esta poesía se ha expulsado, no así la nueva poesía que estos coristas dionisiacos representan como el propio Estado y que se consolida como la verdadera tragedia:

Todo nuestro sistema político consiste en una imitación de la vida más bella y mejor, lo que, por cierto, nosotros sostenemos que es realmente la tragedia más verdadera. Poetas, ciertamente, sois vosotros, pero también nosotros somos poetas de las mismas cosas, autores y actores que rivalizan con vosotros en el drama más bello, del que por naturaleza solo la ley verdadera puede ofrecer una representación, tal como es nuestra esperanza. ${ }^{176}$

La política considerada en este contexto es imitación de la vida "más bella y mejor", esto implica que la política como tal es (y debe ser) semejante a la vida (bios) en tanto es cuerpo vivo, orgánico, que al portar en ella la naturaleza divina, al ser

174. Platón. Leyes. Op, Cit. 817b.

175. Ibid, $817 \mathrm{~d}$.

176. Ibid, Leyes, $817 \mathrm{~b}$. 
posesión de la divinidad, lleva en sí lo bello (Kalós) y lo bueno (agathos). La ley que de este organismo es su resultado, su imagen, es decir, su representación, tiene como condición el conocimiento previo del alma, de su verdad misma que es de origen divino y que solo se da con la iniciación ascética de la dialéctica que prepara a la epopteia (revelación) ${ }^{177}$. La mimesis aquí no es una mera imagen, o representación, la mimesis comporta también un proceso dialéctico que lleva al alma a la visión suprema del Bien. De esta manera podemos ver que mimesis y enthousiasmos (inspiración) no se repelen, sino que se complementan y se determinan. La mimesis que aquí nos presenta Platón es la mimesis inspirada que es la verdadera y buena. Esta determina todas las demás. El Poeta legislador (en la figura del corista sexagenario) es el hombre inspirado por excelencia y es quien marca la pauta misma de la producción poética-política. Todos los demás imitadores o poetas imitativos deben atenerse a sus leyes, los que no lo hagan serán expulsados.

\section{La Política como Mimesis}

Es inevitable luego de leer a Platón, extrañarse por esta propuesta como vía política posible, sobre todo en nuestra época de tintes democráticos (sistema imperfecto para Platón), pero tan rígida en actos realmente creativos. La política como mimesis o como poiesis no tiene, según parece, cabida entre nosotros. Lo político hoy está más del lado del derecho y la economía y alejada de la formación misma del ciudadano. Educar en la política se convirtió en un asunto vocacional orientado a los abogados y economistas (en el mejor de los casos). Ocasionalmente se da en la formación básica y media una orientación insípida sobre constitucionalidad o democracia, haciendo énfasis en la jurisprudencia y en la historia política del país. En la formación superior que debería ser más práctica, es quizás más pobre que la que se recibe en el colegio. La universidad, que debería ser formadora en la libertad a partir de las humanidades y las artes, considera estas disciplinas como una especie de "relleno" que se deben supeditar a la ciencia y la tecnología.

En este sentido la propuesta de la profesora Martha Nussbaum en su libro "Sin fines de lucro"178, en el que hace énfasis en la necesidad de basar la educación en principios humanistas y artísticos para la construcción de una sociedad democrática, rescata los ideales clásicos de formación integral para la libertad. Sócrates y su metodología basada en el diálogo es el primer escalón para alcanzar una conciencia política. Así

177. Según el Profesor Mejía Toro, Jorge Mario. El Teatro filosófico y la Rapsodia. Otra Interpretación del Ion Platónico. Medellín. Universidad de Antioquia. 2003. p.279, "El proceso ascendente hacia las ideas no es ninguna negación de lo vital; es, antes bien, lo propio de la vida en cuanto mortal"

178. Nussbaum, Martha. Sin fines de lucro. Bogotá. Panamericana. 2010. 199pp. 
mismo, las artes en general, pero particularmente la literatura y la música permiten ponerse en el lugar del otro, de "compadecerse" por su semejante. En este caso el teatro es una gran oportunidad de tener este tipo de vivencias, de salirse de sí mismo para representar otro que no soy yo, pero que podría ser. Esta experiencia de alteridad, permitiría una estructuración del individuo más sensible y abierto a los problemas y sufrimientos humanos. Así, la filósofa norteamericana rescata para la educación política el elemento mimético que le permite al ciudadano vivir y representarse para sí el drama humano.

En resumen, vemos cómo la propuesta de Platón de encaminar la vida política de los ciudadanos a través de la poesía y la mimesis no solo no es extraña, sino que es, por el contrario, esencial para su realización. Y no pensemos que se trata meramente de un aspecto metafísico (tan temido hoy por los ciudadanos del siglo XXI), es ante todo una forma de vivir, se trata de la imitación de la vida más bella y mejor, la verdadera tragedia. 


\section{Bibliografía}

Colli, Georgi. La Sabiduría Griega. Madrid: Trotta, 1998.

Cornford, F.M. Principium Sapientiae. Los Orígenes del Pensamiento Filosófico Griego. Madrid: Visor, 1988.

Platón. Obras completas. Madrid. Gredos. 1993-1999.

Platón. Diálogos. México. Porrua. 1998, 787 pp

Mejía Toro, Jorge Mario. El Teatro filosófico y la Rapsodia. Otra Interpretación del Ion Platónico. Medellín. Universidad de Antioquia. 2003.

Nehamas, Alexander. “Acerca de la Imitación y la Poesía en el Libro X de la República de Platón”. En: Estética: miradas Contemporáneas. Compilador: Carlos Eduardo Sanabria B. Bogotá. Jorge Tadeo Lozano. 200. p.21-54

Nussbaum, Martha. Sin fines de lucro. Bogotá. Panamericana. 2010. 199pp.

Rosen, Stanley. "The Quarrel between Philosophy and Poetry”. Studien. In: Ancient Thought. United States. Routledge. 1988.

Verdenius, W.J. Mimesis: "La Doctrina Platónica sobre la Imitación Artística y su Significado para Nosotros", En: Estudios de Filosofía. Universidad de Antioquia. No. 14 Agosto de 1996. pp.11-40.

Vernant, Jean Pierre y VIDAL-NAQUET, Pierre. Mito y tragedia en la Grecia Antigua. Tomo I y II. Madrid: Taurus, 1987. 


\section{EPÍLOGO \\ (A propósito de la noción de innovación en general y del texto mismo)}

Ha sido todo un reto pero también una gran responsabilidad, el poder acercarnos en este texto a Platón y su consideración sobre la mimesis. Responsabilidad en cuanto debemos estar a la altura de la teoría platónica y sus máximos representantes (léase también comentaristas) para poder establecer un diálogo que esté acorde con nuestro contexto académico y ámbitos derivados de este, tales como la educación, la estética, la ética, la política, entre otros.

Fue también un reto por la exigencia que demanda el estudio de la doctrina platónica frente a los parámetros académicos actuales tan exigentes por la necesidad de la innovación, en todo trabajo investigativo. Esto, en términos de producción académica implica tener que decir algo nuevo que aporte a la comunidad en una área tan vasta del saber filosófico como es la filosofía antigua. Desde nuestro punto de vista, este aspecto no solo debe ser tenido en cuenta, sino, además, exige reinterpretarse a la luz de la producción en las humanidades. El carácter de innovación no puede, sin más, tomarse desde un sentido que apunte a las disciplinas de las ciencias duras, sino que debe reinterpretarse para las ciencias sociales y humanas. En el primer sentido se apuntaría a un mero aporte de carácter cuantitativo, bien sea un dato o una información, y su consecuente aplicabilidad; en el segundo sentido se debe orientar hacia la posibilidad de proponer un nuevo horizonte de comprensión, un aspecto ante todo de índole cualitativa.

En esto, consideramos, consiste nuestro aporte: en ofrecer una mirada que se dirige a una concepción "positiva" sobre la mimesis en Platón. Entiéndase "positiva", tanto implica una actualización y, por qué no, una afirmación de su doctrina en torno a un tema que ha sido tratado en general de manera excluyente y negativa: el lugar de la mimesis y la poesía en general, es tratada como algo marginal a su teoría puesto que, por estar alejada en tres grados de la realidad, no tendría una posibilidad real de trascendencia. Actualización en tanto proponemos que las consideraciones platónicas en torno a la mimesis y la poesía en general son todavía vigentes y se pueden aplicar en las diferentes estructuras y producciones humanas contemporáneas tanto en la apreciación del cuerpo, de la educación, de las artes, la ética e incluso en la política. En efecto, la mimesis platónica ocupa un lugar importante en su obra y ello nos lleva a pensar en la posibilidad de pensar un "corpus mimético" que se puede considerar de una importancia semejante a su teoría de las ideas. Es en el propio Platón donde podemos encontrar las pistas para semejante 
afirmación. La primera de ellas la corroboramos en su gran obra de la República, en donde la mimesis aparece bajo su aspecto "negativo". Una segunda pista está tanto en su obra el Fedro, como en el Banquete; es allí donde la mimesis adquiere un cierto carácter iniciático, que permite imitar bien al amado en su elevación hacia las ideas a partir del cuerpo. Una tercera pista la encontramos en las Leyes, donde el poeta legislador instaura con su ejemplo de vida y con su logos, el baremo para instaurar en los demás poetas la mimesis verdadera, que está henchida de inspiración divina. Es en el poeta legislador, donde mimesis e inspiración alcanzan su armonía y su excelencia. En estos distintos momentos en la obra platónica se puede evidenciar el aspecto dialéctico de la mimesis y que muy pocas veces se tiene en cuenta para su estudio. Las más de las veces, insistimos, se quedan en su aspecto negativo, el cual, dicho sea de paso, es necesario también este punto de vista incluso en el propio Platón para resaltar y posicionar la realidad sobre la apariencia; el logos sobre la mentira; la idea sobre lo particular; lo esencial sobre lo contingente.

Consideramos entonces en esta modesta investigación, que la mimesis platónica no solo tiene un carácter positivo, sino que, además, como ya lo mencionamos, recorre la obra de Platón de manera dialéctica y estructural. Esta última visión es la que se pretendió abordar en la investigación, de tal manera que cada capítulo recoge un corpus de textos referidos, primero al cuerpo y a la percepción en su relación con la mimesis, que se actualiza en una manera de ver y representar el cuerpo bello en un contexto contemporáneo como es el de la publicidad o en una imagen mediatizada y sin su carácter formativo; se trata de considerar la mimesis como una encarnación corporal que aspira a la belleza misma en cuanto percepción. Luego, en el segundo y tercer capítulo se recogen textos que apuntan a una propuesta mimética en relación con la poesía y el amor (Fedro) en la relación de amado y amante por una parte, y en la relación poesía-saber y opinión por otra. Por su parte, en el cuarto capítulo se hace la relación de los textos relacionados con la mimesis como creadora de imágenes de cultura y de educación en la Grecia antigua, imágenes-paradigma que, en comparación con nuestra contemporaneidad y contexto hacen pensar en un vacío de modelos que puedan ser imitados. Finalmente en el quinto capítulo se hace la relación mimesis-inspiración y política, para formular un corpus tendiente a explorar el lugar de la mimesis en la propuesta de una polis poiética gobernada por el logos.

Así, desde esta perspectiva entendemos el deber de la innovación en nuestro trabajo. Esta no puede ser sin más un aspecto de carácter cuantitativo que se oriente a medir indicadores y llene estadísticas que se acomodan perfectamente a intereses particulares. Innovar lo entendemos desde un punto de vista, insistimos, cualitativo (si aún es un término que no camufla lo anquilosado de las metodologías en búsqueda de una regla única de aplicación y sistematización) y que por ello no tiene por qué 
hacer parte de mediciones amañadas en el competir científico. Consideramos, incluso, que proponer un problema, fruto de la reflexión es de por sí un "valor agregado" a cualquier investigación, sobre todo en el ámbito de las humanidades. El preguntarse como tal, confrontar, establecer relaciones entre textos, ideas, épocas, entre otras muchas opciones del pensamiento, implica de entrada una novedad, no solo por la diversidad de encuentros que pueden propiciar una relación, sino, sobre todo, en la manera cómo esta se aborda, la perspectiva que aporta. Es posible que para la mirada positivista que busca todavía en lo fáctico y demostrable empírica o cuantitativamente la única verdad incuestionable, un "punto de vista" no haga más que profundizar en la preponderancia subjetiva y pierda de vista el objeto como tal. Lo que no alcanza a comprender este sistema de pensamiento es que él mismo es también un punto de vista subjetivo, pues detrás de la objetividad misma que pretende salvaguardar, no puede negar que quien realiza dichos juicios es otro sujeto más. Por el contrario, desde nuestra perspectiva, el mundo está poblado de infinitas posibilidades de relación, lo cual, a pesar de que se dé también la posibilidad de repetirse, no implica que su modo de presentarse o explicarse tendrá que darse de igual manera (de lo contrario estaríamos hablando de una mera copia o, desde un contexto académico, de plagio). Así, si en este texto hablamos de la relación entre mimesis y cuerpo; mimesis y poesía enamorada; mimesis y opinión; mimesis y educación; mimesis y política, entre otras, no pretendemos decir que estemos con ello inaugurando una nueva posibilidad de darse dichas relaciones (sería el colmo de la ingenuidad), sino que propiciamos una perspectiva entre ellas, que solo podría explicarla y concebirla el mismo que la pensó. En el innovar resuena un entre (in) que re-hace, re-establece, re-para; es el entre el hacer $y$ el volver a hacer o el entre el establecer $y$ restablecer que se impone como un modo diferente de hacer o establecer previo.

Por ese motivo consideramos que un punto de vista no es un mero "parecer" o una posición subjetiva que podría dar cualquiera de acuerdo a ciertas necesidades o tendencias intelectuales. No. En la innovación (considerada bajo esta interpretación humanista), se hace presente de manera radical un hacer de nuevo que establece nuevas relaciones y por lo tanto crea nuevos horizontes. Se trata, pues, ante todo, de un acto creativo que permite abrir otras posibilidades de interpretación pero también de acción. Este acto creativo debe, así mismo, motivar, incentivar a quienes comparten estos textos a seguir re-estableciendo, re-parando, re-haciendo el propio pensamiento en la re-flexión misma que hace sobre sus propios objetos de estudio e investigación. Lo que medirá en última instancia este grado de innovación en este tipo de estudios o de investigaciones dependerá directamente de haber logrado o no este tipo de propuesta de innovación, que no se queda en un mero contemplar (un nuevo punto de vista) sino también en un interactuar de lo pensado con el 
medio, con el contexto en el que nos movemos y vivimos, de tal manera que lleve a reformular problemas y nuevas estrategias de acción y de intervención. La medida de este impacto innovador debe radicar en la manera como el lector lleve a cabo esta misión re-stauradora y re-paradora del pensamiento con su entorno vital. Esta es la invitación y el reto que queremos proponerle a nuestros futuros lectores: participar en la carrera de relevos del saber, llevando la antorcha del conocimiento no como dato e información transferible y cuantificable que se toma y se copia y reproduce cualquier número de veces, sino que la tome para transformarla mediante la reflexión y su problematización. Solo a través de problematizar lo dado (bien se presente como teoría, fenómeno, objeto de investigación, etc.), y actualizándolo en nuestro contexto es que se abren nuevos horizontes para el saber y se multiplican sus posibles relaciones, de tal manera que se le vuelva al portador de un saber, una exigencia el re-establecer o re-hacer dicho objeto (teoría, fenómeno, etc.) con su propia perspectiva y contexto para generar nuevas relaciones, nuevas posibilidades al conocimiento y ofrecerlo a su entorno vital para que siga transformándose y actualizándose en esta carrera de relevos que es la imagen de la ciencia y del saber.

No sería justo con la filosofía silenciar a uno de nuestros grandes filósofos como lo es Martín Heidegger, quien fue un gran crítico con las tendencias tecnocráticas en nuestra época y quien advirtió para el saber y para la academia en general, sobre el peligro de centrarse en las exigencias de un pensamiento técnico y calculador. Es importante subrayar, en este contexto, la importancia de rescatar y privilegiar en nuestra actividad humanística el "pensamiento reflexivo" sobre el "pensamiento calculador" que tan bellamente este filósofo alemán expone en su texto "Serenidad"179. Por ello consideramos importante terminar este texto con una cita que pertenece a este pequeño libro y alude a la característica del pensamiento calculador tan afanado siempre en dar cuenta de todo cuanto ocurre en el modo del dato, del informe y de la noticia, un modo de pensar que "no da tiempo" para la reflexión y el meditar que va en pos del sentido de "todo cuanto es".

¿Qué gran peligro se avecinaría entonces? Entonces, junto a la más alta y eficiente sagacidad del cálculo que planifica e inventa, coincidirá la indiferencia hacia el pensar reflexivo, una total ausencia de pensamiento. ¿Y entonces? Entonces el hombre habría negado y arrojado de sí lo que tiene de más propio, a saber: que es un ser que reflexiona. Por ello hay que salvaguardar esta esencia del hombre. Por ello hay que mantener despierto el pensar reflexivo. ${ }^{180}$ 
El presente texto titulado "Mimesis I: Platón", es la colección de cinco ensayos que giran en torno al tópico de la mimesis en relación con diversos campos, además del arte, tales como la ética, la política, la educación y la corporeidad, los cuales tienen por hilo conductor la filosofía de Platón. En primer lugar, encontramos una aproximación desde el cuerpo como encarnación de la belleza misma que es percibida; luego pasamos a la mimesis encarnada esta vez en los enamorados que expresan su philia por medio de la poesía. Ésta a su vez, a pesar de la crítica de Platón, puede utilizarse en tanto "mentira verdadera" como pharmako contra aquellas "mentiras innobles" a las que recurre el poeta para realizar sus imitaciones. Esto nos conduce al problema de la educación en la que se indaga por aquella representación que movía al espíritu griego en su paideia, como ideal para pensar la educación aún en nuestros días. Finalmente, se retoma la poesía como mimesis e inspiración que se sintetizan en la figura del poeta legislador que determina el modo adecuado de representación para el buen gobierno del Estado. 